\title{
Legal Planning for the Mentally Retarded: The California Experience ${ }^{\dagger}$
}

\author{
Herma Hill Kay'; Louise J. Farnham"; \\ Beth Davis Karren ${ }^{\text {iti }}$; Jeanne Knakal ${ }^{\text {iv }}$; \\ Priscilla Myrick Diamond ${ }^{v}$
}

In a survey paper on mental retardation prepared for the 1960 White House Conference on Children and Youth, Gunnar Dybwad pointed out that insufficient attention had been given to the legal status of inentally retarded persons. ${ }^{1}$ Charging that legal planning for the retarded too often appeared limited to the appointment of a guardian, with its consequent removal of the ward's civil rights, Dybwad challenged legal scholarship to find a way of fitting the degree of legal protection accorded an individual to the degree of handicap he suffered and thus to make the law more responsive to individual needs. ${ }^{2}$

The challenge was taken up and the idea of flexibility supported by the Task Force on Law of the President's Panel on Mental Retarda-

† The research on which this paper is based was carried out by the members of the Family Law Project, which was supported by Grant No. PR-400, U.S. Dept. of H.E.W. (Children's Bureau), D.W. Louisell, Professor of Law, The University of California, Berkeley, Principal Investigator. The assistance of Dr. Erika Chance, who acted as Consultant to the Family Law Project, is gratefully acknowledged. We are also grateful to Mrs. Carol Myers for her editorial assistance.

i. B.A. 1956, Southern Methodist University; J.D. 1959, The University of Chicago; Professor of Law, The University of California, Berkeley; Director, Family Law Project.

ii. B.A. 1958, University of Minnesota; Ph.D. 1962, University of Minnesota; Research Psychologist, Family Law Project; currently Associate Professor, School of Social Science, Hampshire College.

iii. B.A. 1963, Cornell University; LL.B. 1966, The University of California, Berkeley; Research Lawyer, Family Law Project; Member, State Bar of California.

iv. B.A. 1949, Queen's College; M.S.S. 1951, Adelphi University School of Social Work; Certified in Psychotherapy and Psychoanalysis, 1959. Institute of the Postgraduate Center for Mental Health, New York City; Research Psychiatric Social Worker, Family Law Project.

v. B.A. 1958, Mount Holyoke College; LL.B. 1965, The University of California, Berkeley; Research Lawyer, Family Law Project; Member, State Bar of California; State Bar of Massachusetts.

1. Dybwad, Trends and Issues in Mental Retardation, CHIDREN AND YouTH IN THE 1960s 263, 269 (Committee on Studies, Golden Anniversary White House Conference on Children and Youth 1960).

2. Id. 
tion. $^{3}$ Although President Kennedy, in his 1961 speech announcing the Panel's appointment, indicated that mental retardation is a national problem requiring a national solution, ${ }^{4}$ many of the legal problems facing inentally retarded persons, including the question of their legal status, are presented by state rather than federal laws. The panel's report recognized the local nature of these problems by calling upon each state to develop its own comprehensive plan for the retarded. ${ }^{5}$ Similarly, many of the proposals for change made by the Task Force on Law are directed necessarily to the several states.

Congress responded to these recommendations by authorizing planning grants to the states for mental retardation. ${ }^{6}$ Funds were also made available for research. California became the first state to act upon the panel's suggestion that each state develop a comprehensive plan for the retarded, by creating a Study Commission on Mental Retardation in 1963.7 Simultaneously with its creation of the study commission, the legislature established an Assembly Interim Committee on Ways and Means to study mental health service; this committee, too, decided to focus its efforts on mental retardation. ${ }^{8}$

Both the study commission and the assembly interim committee were actively at work when the research to be described in this Article was undertaken. Broadly conceived as a study of the impact of the law on the hives of mentally retarded persons and their families, the research began as a general survey of the legal problems attendant upon parental planning for the future of mentally retarded children. At the time the field work was begun, in early 1965, institutionalization in one of California's four lospitals for the retarded was still the only practical long-term plan available to most parents who were unable to care for their child at home and who lacked the funds to maintain him in a private facility. ${ }^{3}$ Since the path of admission to three out of four of the state hospitals led through the courtrooin and the process of civil commitment, a major part of the research was concentrated on understanding the theoretical basis for requiring court commitment as a part of the

3. The President's Panel on Mental Retardation, Report of the Task FORCE ON LAW 24-27 (1963) [hereinafter cited as TASK FORCE ON LAW].

4. The President's Panel on Mental Retardation, A Proposed Program for National action to Combat Mental Retardation 197-98 (1962) [hereinafter cited as President's Panel].

5. Id. at 165-66.

6. Health, Education and Welfare Indicators XIX-XXV (Nov. 1963).

7. Ch. 935, [1963] Cal. Stat. 2187; Edmund G. Brown, Message on Mental Retardation 1 (Report of the Governor to the California Legislature, May 10, 1965).

8. Subcomm. on Mental Health Services of the Cal. Assembly Interim Comm. on Ways and Means, a Redefinition of State Responsibility for CalFORNIA's MENTALIY RETARDEd 8-9 (1965) [hereinafter cited as AsSEMBLy COMMITTEE].

9. Id. at 16-17. 
hospital admission process, describing the actual practice of commitment in each county of the state, and evaluating the legal implications of commitunent as they affect the mentally retarded. Part I of this Article describes this aspect of the research.

A second goal of the research team was to learn whether, or to what extent, legal considerations motivate some parents to choose the alternative of state hospitalization for their children while others choose to keep their children in the community as long as possible. This aspect of the research is described in part II.

It quickly became apparent that the concept of legal guardianship was central to planning for the future of mentally retarded persons. The basic legal problem was that posed earlier by Dybwad: how could the relatively inflexible concept of legal guardianship be altered so that it could better serve individual needs? The research team saw in this challenge the possibility of fashioning a legal tool capable of coordinating the broad spectrum of services for the retarded and making them available on a personal basis. Part III describes this aspect of the research.

During the field work, the California legislature began consideration of a new approach to civil commitment of the inentally ill. Its study resulted in the Lanterman-Petris-Short Act, enacted in 1967 and effective July 1,1969 , which favored voluntary admission to state hospitals for the mentally ill. ${ }^{10}$ Following completion of the field work in 1968 and during the period of data analysis, the legislative interest in commitunent was extended to the mentally retarded. The Lanterman Mental Retardation Services Act, enacted in 1969 with some changes in 1970 and effective July 1, 1971, prohibits court commitment of any mentally retarded person unless he is a danger to himself or others. ${ }^{11}$ A discussion of the effect of this restriction in court commitunent and other changes made by the Lanternian Act upon the practices reported in part I, as well as some speculation as to its future impact upon the legal treatunent of mentally retarded persons in California, are found in the conclusion.

Before turning to a discussion of the specifically legal aspects of the research, it is appropriate in a nonmedical journal to add a short preface dealing generally with the condition of mental retardation. The reader should clearly understand that this Article deals with the mentally retarded, not with the mentally ill. These two conditions cannot, of course, be separated with precision; it has recently been demon-

10. Cal. ANN. Welf. \& INST'NS Code $\$ \$ 5000-01$ (West Supp. 1971).

11. Cal. Ann. Health \& Safety Code $\$ 38002$ (West Supp. 1971); Cal. ANN. WeLF. \& INST'NS CODE $\$ 6500.1$ (West Supp. 1971). The main part of the Lanterman Act is found in Division 25 ( $\$ \$ 38000-38300)$ of the Health and Safety Code. 
strated that retarded persons are susceptible to the same childhood problems of emotional impairment, personality development, and psychotic or schizophrenic reaction that may affect normal children. ${ }^{12} \mathrm{Ma}-$ jor differences that are significant for legal planning do appear, however, and should be noticed. The most striking of these are that mental retardation tends to be diagnosed quite early in life as compared with mental illness ${ }^{13}$ and that, until recently, mental retardation has been considered a permanent condition. ${ }^{14}$

The retarded, who are generally thought to account for about 3 percent of the total population, ${ }^{15}$ have been stratified into five groups according to their performance on IQ tests: borderline (IQ 70-84); mildly retarded (IQ 55-69); moderately retarded (IQ 40-54); severely retarded (IQ 25-39); and profoundly retarded (IQ 0-24). ${ }^{16}$ Based in part on these categories and in part on functional and social adaptation, the retarded have been assigned to special public school classes, state hospitals, training schools, and community facilities. By far the largest group of persons thus classified as mentally retarded fall into the upper range of the scale. Tarjan has divided the retarded into two main groups: the first group (consisting of 10 percent of all persons classified as retarded) is characterized by severe to inoderate intellectual impairment, a mental age not exceeding that of a normal seven-year-old child, physical handicaps, and specific diagnoses such as mongolisin, brain damage, metabolism errors, and structural anomalies of the central nervous system. The second group (composed of 90 percent of the retarded) rarely are characterized by pliysical signs and have only a mild degree of mental impairment, with IQ's generally over 50 and a mental age equivalent to that of a normal child between 7 and 11 years of age. Tarjan further notes that members of the second group are rarely diagnosed as retarded until they enter school; once adults, many

12. Philips, Children, Mental Retardation, and Emotional Disorder, in PREvention and Treatment of Mental Retardation 111, 112-21 (I. Philips ed. 1966) [hereinafter cited as I. Philips].

13. Koch, Diagnosis in Infancy and Early Childhood, in I. Philips 45, 50-55.

14. Perry, Notes for a Sociology of Prevention in Mental Retardation, in I. Philips 145, 165.

15. President's Panel 1; but see Tarjan, Mental Retardation: Implications for the Future, in I. Philips 429, 432:

[M]t can be stated that 3 per cent of the newborn will manifest mental retardation. It is misleading, however, to say that 3 per cent of the population is retarded. Direct transfer of incidence data to prevalence is justified only when the condition is identifiable at the same age in each afflicted individnal, when the condition remains unchanged, and when mortality rates are not affected by it.

16. Heber, Modifications in the Manual on Terminology and Classification in Mental Retardation, 65 Am. J. Mental Deficiency 499, 500 (1961). For a discussion of earlier terminology, see Dybwad, supra note 1, at 264-65. See also M. ADAMS, Mental Retardation and Its Social Dimensions 5-7 (1971). 
of them "make a marginal or reasonably adequate adjustment, cease to be labeled as retarded, and become reabsorbed in the general population." $" 17$

Despite the numerically larger size of the second group, the popular image of the retarded appears to be based on the smaller group of moderately and severely retarded persons. Moreover, as Philips has pointed out, planning for the large group has been neglected in favor of developing programs for the smaller group whose needs are primarily medical and rehabilitative. ${ }^{18}$ This focus of attention, in turn, has tended to reinforce the relatively unsophisticated and inflexible legal planning that assumes all groups of the retarded to be alike. But the past 10 years have witnessed an enormous resurgence of professional interest in the mentally retarded, ${ }^{10}$ and, based upon the more precise medical, social, and behavioral information now available about the retarded, the task of legal planning for their needs can be more constructively undertaken.

\section{I}

\section{Court COMmitment and Hospital Admission for the Mentally RetaRded Prior to 1971}

\section{A. The Statutory Framework}

Califorma's first code in 1872 established a court commitment procedure for the mentally ill to the only state institution then available for their care, the State Insane Asylum at Stockton. ${ }^{20}$ The same code expressly provided that "no case of idiocy or imbecility ... . must be maintained at ... the asylum." ${ }^{21}$ The first state institution for the mentally retarded, called the California Home for the Care and Training of Feeble-minded Children, was not established until 1885. ${ }^{22}$

Two years later the basic admission pohicy for the retarded changed from the voluntary procedure originally available to a policy of court commitment: the Act of 1887 provided that a parent, guardian, or other person charged with the support of a retarded child who desired his admission to the Home might petition the court in his county of residence

17. Tarjan, Research and Clinical Advances in Mental Retardation, 182 J.A.M.A. 617,618 (1962).

18. Philips, Children, Mental Retardation and Planning, 35 AM. J. ORTHOPsYCHIATRY 899, 901 (1965).

19. Id. at 900 . See also Tarjan, supra note 15 , at 438.

20. Former Political Code $\$ \S 2210-27$ (1872), repealed, ch. 364, $\S 1$, [1903] Cal. Stat. 485.

21. Id. $\$ 2225$.

22. Ch. 156, $\S 1$, [1885] Cal. Stat. 198. For a history of Sonoma State Hospital, see E. Pond \& S. Brody, Evolution of Treatment Methods at a Hospital for the Mentally Retarded, (Cal. Dep't of Mental Health Research Monograph \# 3, 1965). 
for an order admitting the child into the Home. ${ }^{23}$ The court was instructed to "inquire into the condition and status" of the child and to make the order of admission only if the child was an "imbecile or feebleminded" person between the ages of 5 and 21 who was incapable of receiving instruction in the common schools, and who had been a resident of the state for one year. Although the court's order was to provide "that said child be received into, and maintained and educated in said Home," child if no facilities were then available for his care. At the hearing, the court was directed to inquire into the financial condition of the parent or other person having charge of the child and, if applicable, to make an order for the child's support during his lospitalization.

A voluntary admission procedure was also available, if the Home's capacity permitted, for nonresidents of the state whose cost of care was paid and for any applicant for lifetime care who could make an acceptable donation to the Home's maintenance. ${ }^{25}$ Since the state would provide for the care of those patients who were court committed if their parents or guardian were unable to contribute to their support, the Act of 1887 established a precedent for different financial treatment of voluntary patients and court-committed patients.

The basic sections governing state institutions for the mentally ill and the mentally retarded were completely rewritten in $1903 .{ }^{26}$ At that time five state hospitals existed for the insane and only one hospital, located at Eldridge in Sonoma County, for feebleminded children. ${ }^{27}$ The method of admission to the hospitals for the mentally ill continued to be limited to court commitment. ${ }^{28}$ The statute also preserved court commitment and voluntary admission as the two methods of admission to Sonoma. ${ }^{29}$ The sections governing court commitment were not substantially changed, ${ }^{30}$ but other significant changes were made. The class of potential Sonoma patients was enlarged to include idiots and epileptics who were not insane as well as imbeciles and feebleminded

23. Ch. 57, § 7, [1887] Cal. Stat. 71. See also E. PoND \& S. BRODY, supra note 22 , at 16 .

24. Ch. 57, § 7, [1887] Cal. Stat. 71.

25. Id. $\$ 8$, at 71-72. See also ch. 149, \& 3, [1889] Cal. Stat. 156 (amending section 8 to require that moneys received from these sources be used "only for the maintenance of the inmates of the Home").

26. Ch. 364, $\$ 1$, [1903] Cal. Stat. 485 [hereinafter cited according to numbers in the Political Code of 1903]. See also E. Pond \& S. BRody, supra note 22, at 10.

27. Political Code of $1903 \S 2145$, [1903] Cal. Stat. at 490-91.

28. Id. $\S \S 2167-75$, [1903] Cal. Stat. at 502-05. Section 2185, lieaded "Admission under Special Agreement," seems to have been limited to special agreements for in-hospital care of patients already committed.

29. Id. \$ 2192-95, [1903] Cal. Stat. at 511-12.

30. Id. $\S 2192$, [1903] Cal. Stat. at 511. See text accompanying notes 25-26 supra. 
persons. ${ }^{31}$ And, despite the retention of the institution's name as the California Home for the Care and Training of Feeble-minded Children, the age restrictions for admission were eliminated. ${ }^{32}$ Perhaps the most significant change, however, was the power given to the Home's superintendent to refuse admission to a court-committed patient not merely on the grounds that the hospital was already full or its funds exhausted, as the Act of 1887 had provided, ${ }^{33}$ but also on the ground that in the judgment of the hospital administration or the state Commission on Lunacy, the patient was not a suitable subject for adınission. $^{34}$ The hospital was thus clearly given the power of final decision over admissions and was in a position to reverse the court's commitment order. This structural arrangement was to have a critical impact on the development of the court-commitment process.

The Act of 1903 began the tradition of contribution by the county of commitment to the support of patients committed ${ }^{35}$ to Sonoma. The contribution was not required for voluntary patients, and no similar requirement was placed on the counties to contribute to the support of patients who were committed to the state hospitals for the mentally ill, although the statute made clear that the contributions for Sonoma patients were to continue even if they were transferred to one of these hospitals. $^{36}$ The amount of the county's contribution was fixed at $\$ 10$ per month for each patient and appears initially to have been intended as a supplement to whatever support order had been iniposed on the parents or other responsible persons. ${ }^{37}$ In 1909, however, the section was amended to make clear that the county obligation arose only if the parents or other responsible persons were not ordered to make the payments or did not make them if ordered. ${ }^{38}$

Changes were also made by the 1903 Act in the procedure for voluntary admission. The board of managers was admonished to consider the interests and welfare of persons already committed to the Home or awaiting admission to it before accepting voluntary patients. ${ }^{30}$ Moreover, in addition to their contributions to the hospital provided for in the $1887 \mathrm{Act}^{40}$ voluntary patients were now required to pay for the actual cost of their care during hospitalization. ${ }^{41}$ A provision was in-

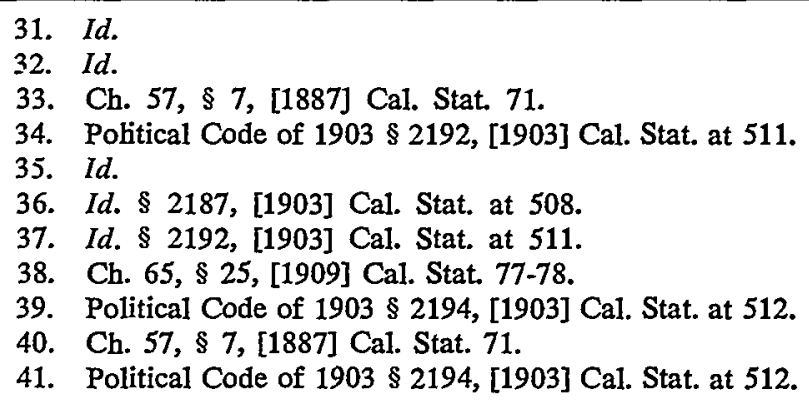


cluded to protect the status of the voluntary lifetime-care patients already in the hospital, but other patients who were not self-supporting by the value of their labor or whose cost of support was not met by the contributions of others could, in the discretion of the Commission on Lunacy, be discharged from the hospital. ${ }^{42}$

The final major recasting of the basic statutory provisions dealing with hospital admission for the mentally ill and the mentally retarded prior to the commencenent of the research to be described in this Article occurred in 1937 . In that year the legislature created a State Department of Institutions to supplant the old Commission on Lunacy and a new code, the Welfare and Institutions Code, to replace the old Political Code as the basic repository of statutory law governing the mentally ill and the inentally retarded. ${ }^{43}$ The new law repealed section 2194 of the Political Code, ${ }^{44}$ which had allowed voluntary admission to Sonoma; but for a period of approximately three months following the new enactment, voluntary patients were allowed to enter Pacific Colony (the new state institution for the retarded in Los Angeles County) even though they were not eligible for Sonoina. ${ }^{45}$ After this discrepancy was ended, the only voluntary patients eligible for admission to either Sonoma or Pacific were persons "suspected of being feeble-minded" who were admitted for temporary observation and diagnosis. ${ }^{46}$ Even these patients had to be readmitted to the hospital via the normal route of court commitment if the diagnosis was affirmative. ${ }^{47}$ At the same time that it was requiring the mentally retarded to undergo court commitment as a step in hospital admission, however, the legislature allowed a 1911 provision permitting voluntary admission to the state hospitals for the insane of persons "suffering from a mental disease" who met other conditions imposed on eligibility ${ }^{48}$ to be carried over into the new Welfare and Institutions Code. ${ }^{49}$

42. $I d$.

43. Ch. 369, [1937] Cal. Stat. 1005 [hereinafter cited as Welf. \& Inst'ns Code of 1937].

44. Id. $\S 20000$, [1937] Cal. Stat. at 1182. There was a savings provision for the lifetime-care patients aleady in the hospital. Id. $\$$ 7014, [1937] Cal. Stat. at 1169.

45. Id. $\$ 7068$, [1937] Cal. Stat. at 1172 . Chapter 369 originally had separate provisions dealing with Sonoma (\$\$ 7000-10 [1937] Cal. Stat. at 1166-67) and the Pacific Colony ( $\$ \S 7050-81$, [1937] Cal. Stat. at 1170-74) which were effective as of May 25, 1937. [1937] Cal. Stat. at 1005 (note). These separate provisions were repealed and new sections enacted covering both institutions. Id. $\$ \S 7000-15$, [1937] Cal. Stat. 1168-70 (effective August 27, 1937). Old $\$ 7068$ was not reenacted. See generally Elliott, The Work of the 1937 Legislature: Feeble-Minded Persons, 11 S. CAL. L. REV. 1, 127 (1937).

46. Welf. \& Inst'ns Code of $1937 \S 7007$, [1937] Cal. Stat. at 1168.

47. Id. Code).

48. Ch. 277, $\S 1$, [1911] Cal. Stat. 465-66 (adding $\S 2185 \mathrm{~b}$ to the Political

49. Welf. \& Inst'ns Code of 1937 \& 6602, [1937] at 1153. 
The basic sections of the 1937 code setting out the procedures for court commitment of the mentally retarded ${ }^{50}$ have not been substantially altered by more recent amendments although changes have been made in the class of persons subject to court commitment. ${ }^{51}$ Probation officers and district attorneys were added to the list of persons who might petition for commitment along with parents, guardians, and others charged with the support of a feeblemminded or epileptic person. ${ }^{62}$ A new section was added defining "feeble-minded" persons as

those persons, not insane, who are imcapable of managing themselves and their affairs independently, with ordinary prudence, or of being taught to do so, and who require supervision, control, and care, for their own welfare, or for the welfare of others, or for the welfare of the community. ${ }^{53}$

The code required that notice of the commitment hearing be given to the alleged incompetent and, if a probation officer or district attorney acted as the petitioner, to his parent, guardian, or other person responsible for his support. ${ }^{54}$ The basic provision of the 1887 code $^{65}$ that the court "inquire into the condition or status" of the person for whom the order was sought was continued ${ }^{56}$ and appears in the code today. ${ }^{57}$ Special provision was made for the appearance of expert witnesses: their fees and expenses were to be paid by the parent, guardian,

50. Id. \$§ 5250-64, [1937] Cal. Stat. at 1137-39.

51. See note 84 and text accompanying note 272 infra.

52. Welf. \& Inst'ns Code of $1937 \& 5252$, [1937] Cal. Stat. at 1137. The complete list now includes the Youth Authority, or any person designated to act as petitioner by the court (both added by ch. 481, $\$ 62,[1943]$ Cal. Stat. 1983) and the Director of Corrections. CAL. Welf. \& INST'NS CODE $§ 6502$ (West Supp. 1971).

53. Welf. \& Inst'ns Code of $1937 \S 5250$, [1937] Cal. Stat. at 1137. The modernization of terminology that swept other states [see R. ALLEN, E. FersTer \& H. WeIHOFEN, MENTAL IMPAIRMENT AND LEgal INCOMPETENCY 32-45 (1968) [hereinafter cited as ALLEN and referred to in the text as Mental Incompetency Study]] also affected California: the phrase "Inental illness" was introduced in 1939 [ch. 295, § 3, [1939] Cal. Stat. 1549], and the "feeble-minded" became the "mentally deficient" in 1945 and the "mentally retarded" in 1967 [ch. 137, \& 1, [1945] Cal. Stat. 622 (amending \& 5250); CAL. ANN. Welf. \& INST'NS CODE \& 6500 (West Supp. 1971) (effective July 1, 1969)]. The defimition section as amended in 1945 identified the mentally deficient as those persons, not psychotic, who are so mentally retarded from infancy or before reaching maturity that they are incapable of managing themselves and their affairs independently, with ordinary prudence, or of being taught to do so, and who require supervision, control, and care, for their own welfare, or for the welfare of others, or for the welfare of the coinmunity.

Ch. 137, § 1, [1945] Cal. Stat. 622. A second paragraph was also added that equated "feeble-mindedness" with "mental deficiency" in other sections. Sonoma and Pacific were renamed "Homes for the Mentally Deficient." The "mentally deficient" were renamed the "mentally retarded" in 1967, but the definition otherwise remained the same. CAL. ANN. Welf. \& INST'NS CODE $\$ 6500$ (West Supp. 1971).

54. Welf. \& Inst'ns Code of $1937 \S 5254$, [1937] Cal. Stat. at 1137.

55. See text following note 23 supra.

56. Welf. \& Inst'ns Code of $1937 \S 5257$, [1937] Cal. Stat. at 1138.

57. Cal. ANN. Welf. \& INST'NS CODE $\$ 6507$ (West Supp. 1971). 
or other person responsible for the retardate's support or, failing that, by the county. ${ }^{58}$ The financial inquiry of the persons responsible for the support of the mentally retarded person was continued, but the 1937 version provided that any support money ordered was to be paid to the county rather than to the hospital. ${ }^{59}$ If the court found that the person was epileptic or feebleminded and that the residence provisions were met, the commitment was to Sonoma or Pacific, subject to the superintendents' power to deny admission to unsuitable persons. ${ }^{60}$

A final development in the legislative history of hospital admission for the mentally retarded occurred in 1961. The 1937 legislation permitting the voluntary admission of the mentally ill ${ }^{61}$ had been broadened in 1943 to allow any person "suitable" for care and treatment in a state hospital to apply for voluntary admission. ${ }^{62}$ In response to a 1960 opinion of the attorney general, ${ }^{63}$ which read this language as limited to the mentally ill, a new section was enacted in 1961 expressly providing for voluntary admission of the mentally deficient under section $6602 .{ }^{64}$

As the legislative history indicates, both court commitnent and voluntary admission were available to the mentally retarded as alternative means of entry to the four state hospitals established for their care. The choice between these alternatives was not, however, left entirely to the mentally retarded person and his parents. Each of the four hospitals had chosen for its patients a preferred method of admission, and each was shightly different. At the commencement of the field study in 1965, Pacific State Hospital, located in Los Angeles

58. Welf. \& Inst'ns Code of $1937 \S \S 5257,5261$, [1937] Cal. Stat. at 1138-39, now CAL. ANN. WeLF. \& INST'NS CODE $\$ \$ 6507-08$ (West Supp. 1971).

59. Id. $\$ 5260$, [1937] Cal. Stat. at 1138, now CaL. ANN. WeLf. \& INST'Ns CODE $\$ 6715$ (West Supp. 1971).

60. Id. § 5258, [1937] Cal. Stat. at 1138, now CaL. ANN. Welf. \& InsT'Ns CODB $\S 6509$ (West Supp. 1971).

61. Id. \$ 6602, [1937] Cal. Stat. at 1138, now CAL. ANN. Welf. \& INST'NS CODB $\$ 6509$ (West Supp. 1971). See text accompanying notes 43-49 supra.

62. Ch. 577, $\$ 1$, [1943] Cal. Stat. 2146 (amending $\$ 6602$ ).

63. 35 Op. Cat. Atry. GeN. 31 (1960). In relying in part on sections indicating that the parents of voluntary patients would be charged more for their care than the parents of court-committed patients and concluding that therefore an absurd result would follow, the Attorney General apparently overlooked the financial distinction betweeu these classes of patients established by the Code of 1887. See text following note 25 supra.

64. Ch. 460, § 1, [1961] Cal. Stat. 1539 (adding section 5265). Renumbered in 1965 and consolidaled with the provision governing voluntary admission of the mentally ill [ch. 391, \& 4, [1965] Cal. Stat. 1629, 1688 (renumbered section 6050)], the new section was again renumbered in 1967 and remains the law today. CAL. ANN. WELF. \& INST'NS CODE $\$ 6000$ (West Supp. 1971). The Lanterman-Petris-Short Act of 1969 , which made sweeping clianges in the hospitalization of the mentally ill, expressly did not apply to the mentally retarded. Id. $\S 5002$. 
County and serving the three counties of Los Angeles, San Bernardino, and Riverside, preferred to have all patients under 21 admitted voluntarily by their parents or guardian and to have court orders of commitment entered when the patients became 21. Porterville State Hospital, located in Tulare County and serving the 21 central counties of the state, preferred to have all patients over the age of 16 committed to the hospital. Fairview State Hospital, located in Orange County and serving the three southernmost counties of Orange, San Diego, and Imperial, preferred court commitment of patients who were 19 and older. These three hospitals used court commitment for children whose parents could not be located and for whom no guardian had been appointed. Sometimes court commitment was also deemed appropriate when divorce proceedings or juvenile court involvement appeared in the case.

In contrast, Sonoma State Hospital, located in Sonoma County and serving the 31 counties of northern California, uniformly required court commitment as an integral part of the admissions procedure. ${ }^{05}$ Sonoma's then-current superintendent explamed this policy to members of the research team in 1965 . First, he felt that court commitment was a psychological kindness to the patient's parents, who could reassure themselves that the court, not they, had actually placed their child in the institution. Too, court commitment increased the hospital's authority over the child as against his parents. Finally, the hospital did not wish either to return the patients to their various 31 counties of residence for court commitment when they became 21 or, alternately, to burden the court in Sonoma County with the job of processing all of Sonoma's patients through court commitment at 21 .

Any evaluation of the court-commitment process for the mentally retarded, whatever its justification, necessarily begins with a detailed examination of the process itself. Accordingly, interviews with judges and court personnel, court observations, and interviews with parents (both those whose children had been committed and those whose children had been admitted by parental consent) were undertaken. The commitment process itself, as it affected the mentally retarded and their families in California prior to July 1, 1971, is described next.

\section{B. The Commitment Process}

Within the limits of existing facilities and the current budget, California law gives to the Department of Mental Hygiene ${ }^{00}$ the power

65. Sonoma State Hospital, Parents Handbook 2 (D. Miller ed.). During the field study, Sonoma changed its official policy to encourage voluntary admission of children under 18.

66. Cal. ANn. Welf. \& INST'NS Code $\$ 6509$ (West Supp. 1971). See text 
of final control over hospital admission for the mentally retarded. A court's order of commitment cannot guarantee immediately available bed space. This structural arrangement means, in practice, that a patient has already been accepted by the hospital before a court commits him to its care. For the hospitals that required it, court commitment was treated merely as an additional step in the application procedure. That simple fact of timing had a profound impact on the entire commitment process and a debilitating effect on judicial involvement in decisionmaking affecting the retarded.

\section{Role and Function of the Hospital's Local Agents}

The application procedure began, for families who lived in the 55 counties served by Sonoma, Fairview, and Porterville State Hospitals, at the county level. Each of these hospitals had establislied local agents whose job was to help families make application to the hospital on behalf of their children. ${ }^{67}$ Pacific alone liad not estabhished local agents, preferring that the families in the three counties it served contact the hospital directly. Even for Pacific, lowever, a local agency helped to process the court commitment of those patients for whom it was thought necessary.

The research team sent letters to the judge who presided over commitment hearings and to the local agency handling these cases in each of the 58 counties of the state, explaining the project and requesting either a personal interview or the completion of a questionnaire. Fortynine judges responded; of these, 38 were interviewed personally by one of the two staff attorneys, nine completed written questionnaires, and two refused to cooperate in any way. Fifty-six local agents responded from 52 counties; of these, 38 were interviewed personally by one of the two staff attorneys, 15 completed questionnaires, and three had no relevant information to give due to lack of case materials. Thus, unless the text indicates otherwise, responses reported here are based on a sample of 47 out of 58 judges, or 81 percent of the total judges who were sitting on commitment cases during the field work, and agents representing 49 out of 58 counties. Simce only 56 counties used local agents, the responding agents who had information to give represented 87.5 percent of the total agents active during the field-work period.

accompanying note 36 supra. The Department of Mental Hygiene was created in 1945, supplanting the old Department of Institutions as the state agency having jurisdiction over the state hospitals for the mentally retarded and the mentally ill. Ch. 665, [1945] Cal. Stat. 1334.

67. In the overwhelming majority of cases studied, the retarded person was a minor child. In some cases, where he was legally an adult, his parents or guardian were the nominal applicants for his admission to the hospital. The word "child" is often used in the text to refer to both minor and adult children. 
The agents' responses established a fairly consistent pattern. Of the 56 agents who responded, 46 were probation officers located in county probation departments. Omitting the three agents without information leaves 43 probation officers. Of these 43,41 handled both the job of processing applications for hospital admission and the task of assisting the court with the commitunent procedures. Two other probation officers handled only the court-commitment procedures. In one of these two counties and in the six remaining counties, including the large urban areas of the state, 10 agents were located in agencies outside the probation department. Four were in county departments of public health, ${ }^{68}$ three in special mental retardation units under the jurisdiction of the Department of Mental Hygiene, ${ }^{60}$ one in the Medical Social Services Division of the county Medical Services Departinent, ${ }^{70}$ one at the local state hospital for the retarded, ${ }^{71}$ and one was a district attorney. ${ }^{72}$

The 10 nonprobation agents were further divided into three groups, as shown in table $1:^{73}$ the first is composed of six agents from five counties ${ }^{74}$ who handled only the job of processing applications for hospital admissions (five located in county agencies and one at the state hospital) and did not themselves handle commitment procedures. The second group is composed of two agents ${ }^{75}$ who handled both admissions and commitments, while the third group contams two agents ${ }^{78}$ who did only commitinents. Agents in the first group who did not handle commitments themselves rehed upon other local agencies to perform this task: two used the court clerk, ${ }^{77}$ one used the probation officer, ${ }^{78}$ two used the district attorney, ${ }^{70}$ and one used a mental health counselor. ${ }^{80}$

For the local agent, placement within the county organizational structure seemed less significant, in determining his approach to his job, than whether his job was solely commitments, solely admissions, or both

68. Marin, San Francisco, and two agents from San Mateo.

69. Alameda, San Diego, and Sacramento.

70. Contra Costa.

71. San Diego (Fairview State Hospital).

72. San Mateo.

73. Two of the ten agents were from San Mateo connty. In table 1 the two San Mateo agents are counted as one, giving a total of nine rather than ten, because their practices were reported as identical.

74. Marin, San Diego, San Francisco, San Mateo, and Sacramento. San Mateo had two agents. See note 73 supra.

75. Alameda, Contra Costa.

76. San Diego, San Mateo.

77. Marin, San Francisco.

78. Sacramento.

79. San Mateo (two agents).

80. San Diego. 
commitments and admissions. Thus, to take the most extreme example available on the existing data, both the district attorney and the mental health counselor who were responsible only for court commitments followed identical procedures; neither was significantly distinguishable from the two probation officers whose only job was commitments. The two nonprobation officers who handled both applications and commitments are indistinguishable from the average probation officer in their operating procedure, although they are distinguishable on the basis of educational background. ${ }^{81}$ Although there were no probation officers in the sample who handled admissions only, the practices of nonprobation county agents whose duties were so limited were identical to the admissions practices of probation officers assigned both admissions and commitments functions.

The overall admissions procedure to the three state hospitals whose process included court commitment for some or all patients may be generally described as follows: A parent or family seeking hospital admission for a retarded child would be referred to the local county agent by private physicians, local departments of health or welfare, public schools, and occasionally by the hospitals themselves. Each hospital required that a lengthy questionnaire be filled out by the parents, and the way its completion was handled determined the number of actual interviews the parents had with the agent. Some agents had established a four-step interview process, using the first office interview to see a parent, usually the mother, and to give her the questionnaire. The second interview normally took place some weeks later when the mother returned the questionnaire to the agent and they went over it together. The questionnaire was then mailed to the hospital, and a date was set for the parents to bring their child to the hospital for a preadmission examination. The third interview took place between the agent and the family following the preadmission day at the hospital, and the family was placed on a waiting list for hospital admission. When the hospital notified the agent that bed space was available for the retarded child, the agent scheduled a fourth interview to have the commitment petition signed and to make a court appearance. Only four agents, all probation officers, reported that they routinely scheduled all four interviews. Fourteen probation officers and three nonprobation agents saw the family three times; 14 other probation officers and three nonprobation agents saw the family twice. Eight probation officers and one nonprobation agent saw the family only once.

Each agent was asked whether he normally saw the mentally retarded person as part of the admissions procedure, whether he explained the court procedure to the family, whether he prepared the

81. See text accompanying note 83 infra. 
commitment petition himself, whether he personally appeared at the commitment hearing, whether he testified at the commitment hearing, whether he thought court commitment was necessary, whether he routinely sought other resources for the retarded child apart from the state hospital, whether he maintained contact with the case after commitment, whether he had visited the particular state hospital for the retarded which he represented, whether he routinely visited the home of the family seeking admission for their child, whether he felt his agency was the proper one to be handling the particular task done, and what percentage of his time was spent in working with the retarded. The responses to those questions are shown in table 1.

As table 1 indicates, no uniform practice existed as to whether the local agent actually saw the allegedly retarded person during the commitment and application process. Only 16 of the probation officers mdicated that they routinely saw the retardate at either their offices or his home and only seven - all from rural counties-usually visited the home. The agents who did not routinely see the retardate typically explained that they felt the hospital's preadmission examination made their seeing him unnecessary. Those who did wish to see the retardate often saw him at the mitial interview prior to the exannination and felt the visit lrelped them understand the family's situation. Others, who said they saw the child only if his mother happened to bring him along to an office interview, did not seem to place particular value on the experience.

Tabie 1. Reported Practices of Local Agents.

\begin{tabular}{|c|c|c|c|c|c|c|c|c|c|c|c|c|c|c|c|c|c|}
\hline & \multicolumn{8}{|c|}{ Probation Officers (43) } & \multicolumn{9}{|c|}{ Nonprobation County Officers (9) } \\
\hline & \multicolumn{4}{|c|}{$\left|\begin{array}{c}\text { Commitments (41) } \\
\text { and Applications }\end{array}\right|$} & \multicolumn{4}{|c|}{$\begin{array}{c}\text { Commitments } \\
\text { only (2) }\end{array}$} & \multicolumn{2}{|c|}{$\left|\begin{array}{l}\text { Commitments and } \\
\text { Applieations (2) }\end{array}\right|$} & \multicolumn{3}{|c|}{$\begin{array}{c}\text { Commitments } \\
\text { ofly (2) }\end{array}$} & \multicolumn{4}{|c|}{$\begin{array}{l}\text { Applications } \\
\text { ofly (5) }\end{array}$} \\
\hline & $\stackrel{n}{x}$ & $\stackrel{0}{z}$ & 产 & 辜 & 3 & & : & 意 & 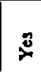 & 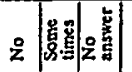 & 3 & & 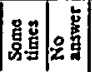 & 3 & 2 & 昜 & 是 \\
\hline See retarded person? & 16 & 17 & 7 & 1 & & 2 & & & & 2 & & 2 & & 3 & 2 & & \\
\hline $\begin{array}{l}\text { Explain court } \\
\text { proceedings? }\end{array}$ & 38 & & & 3 & 2 & & & & 2 & & 2 & & & 5 & & & \\
\hline Prepare petition? & 36 & 4 & & 1 & 2 & & & & 2 & & 2 & & & $\overline{1}$ & 4 & & \\
\hline Attend courn? & 38 & 2 & & 1 & 2 & & & & 1 & 1 & 2 & & & 1 & 4 & & \\
\hline Testify at court? & 18 & 21 & 1 & 1 & 1 & 1 & & & & 2 & 1 & 1 & & 4 & 1 & & \\
\hline $\begin{array}{l}\text { Believe court } \\
\text { recessary? }\end{array}$ & 29 & 9 & 2 & 1 & & 1 & & 1 & 1 & 1 & 2 & & & 2 & 2 & 1 & \\
\hline $\begin{array}{l}\text { Seek other } \\
\text { resources? }\end{array}$ & 16 & 23 & 1 & 1 & & 2 & & & 2 & & & 2 & & 5 & & & \\
\hline Maintain contact? & & 41 & & & & 2 & & & & 2 & & 2 & & & 5 & & \\
\hline Visit Lospital? & 33 & 4 & & 4 & 2 & & & & 2 & & 2 & & & 4 & & & 1 \\
\hline Visit home? & 7 & 23 & 10 & 1 & & 1 & & 1 & & 2 & & 2 & & 1 & 3 & & 1 \\
\hline $\begin{array}{l}\text { Believe your } \\
\text { agency proper? }\end{array}$ & 30 & 9 & & 2 & 2 & & & & 2 & & 1 & 1 & & 5 & & & \\
\hline
\end{tabular}

The 43 probation officers and four nonprobation agents whose duties included or were limited to assistimg with the court commitment procedure itself reported significantly consistent practice from all parts 
of the state. All probation officers and agents who answered the question indicated that they did explain the court procedure to the parent or other petitioner; although their explanations of the need for and results of the court proceeding varied substantially, ${ }^{82}$ some explanation was always offered. Thirty-eight probation officers and all four of the nonprobation agents prepared the petition and other moving papers to be used by the court at the commitment hearing. Forty of the probation officers and three of the agents attended the commitment hearing. Whether the officer or agent routinely gave testimony at the hearing varied: 19 probation officers and one nonprobation agent usually testified in court, while 22 officers and three agents did not normally testify.

The great majority of local hospital representatives had visited the hospital whose policies they represented in the community-many more than once. Perhaps predictably, most of the representatives beheved their agency was the proper one to do the job for the retarded assigned to it. Nonetheless, nine probation officers thought that other agencies, usually public health or mental hygiene, should be handling hospital adinissions and commitments. As table 1 indicates, only the seven nonprobation agents who process applications routimely sought resources for the retardate other than the state hospital.

The only question on which unanimity was achieved was whether the local representative kept up active contact with the family or the retarded person following commitment. All 43 probation officers and all nine nonprobation agents said they did not maintain contact with the case after the court hearing.

The educational background of the local representative and the amount of time he spent in working with retarded persons were the only two factors that varied significantly according to the representative's agency placement. The probation officers generally had less formal training than the nonprobation agents and spent a proportionately smaller part of their working time with the retarded than did the agents. Thus, of the 43 probation officers, only three had advanced degrees while six out of 10 nonprobation agents held advanced degrees. ${ }^{83}$

Only five out of 33 probation officers reported that they spent 10 percent or more of their time with the retarded, and none reported spending more than 25 percent of their time on these cases. On the

82. See text preceding note 92 infra.

83. None of the nonprobation agents had only a high school education, but eight probation officers were in that category; eight others had completed only two or three years of college in addition to high school as coinpared to one nonprobation agent. Seventeen probation officers and three nonprobation officers held college degrees. 
other hand, seven out of eight nonprobation agents said they spent more than 10 percent of their time with the retarded, and four of those seven reported spending at least 50 percent of their time with these cases.

Within the structure imposed by the requirements of the job to be done, a great deal of discretion was left to local hospital representatives to work out individual approaches. The following accounts, based on personal interviews, illustrate both the agent's perception of his task and the variety of procedures that were used to deal with the retarded and their families.

County $A$. This county's agent is an experienced social worker in the medical social services division of the county hospital. She describes her duties as "anything having to do with mental retardation" and indicates that approximately 50 percent of her time is spent with hospital applicants.

The agent initially interviews the parents in her office for approximately one and one-lialf hours. She asks that the retarded person not accompany the parents, since she believes they will talk more freely in his absence. In this period the agent hopes to accomphsh three things: First, to permit the parents to discuss fully the problems they are having with the child ("how the neighbors don't want their children to play with the retarded child, the cruel things that are said, the impact on other children in the family, how the retarded child is God's way of punishing the parents"); second, to inform the parents of other possible community resources ("We want to help them find the right place"); and, finally, to assist the parents in filling out the lengthy and complicated hospital application form ("It would be devastating to the parents if it were just sent to them in the mail"). If the time allowed for the first interview is consumed in letting parents talk, this agent makes a later appointment to fill out the forms. She inentions briefly to the parents during the first interview that there will be a short court hearing, but due to the parents' somewhat dazed or disturbed condition at the imitial meeting, she does not go into detail until after the date for hearing has been set. Gathering the available medical, diagnostic, and social information about the child from all pertinent sources, she sends these reports, with the application form, to the hospital. The hospital then arranges with the parents for the child to be brought to the hospital for a preadmission examination. If the child is deemed eligible and suitable for hospital treatment, the parents and the agent are notified of the specific date on which the child may be admitted.

Between the preadmission examination and the admission date, there may be an extended waiting period of anywhere from six months to two or three years. During this time the agent sees the family "as 
often as they may need help" and talks with them "innumerable times" by telephone to offer encouragement, reassurance, and assistance when emergencies develop.

When the hospital notifies her of the admission date, the agent prepares the commitment petition, which is signed by a parent as petitioner, and has the matter set for hearing by the court. She then meets with the parents and describes the hearing to them in detail, including a description of the physical arrangements (in the psychiatric unit of the county hospital) and her view of the purpose of the proceedings ("to give custody and control to the hospital in an emergency if the parents are not available"). She attends the hearing, testifies if the court requests her to do so, and finally drives the parents to the office of the county clerk where the order is filed and copies are given to the parents. She schedules only one hearing a day so that she can be available to spend time with the parents if they need her ("They may fall apart after the hearing; it's so final'). The parents then drive the child to the hospital or the agent does so herself. This is her final official contact with the family, although the parents sometimes call to tell her about their visits to their child in the hospital.

County $B$. The hospital agent for county $B$ is a probation officer who supervises the Dependent Children's Umit of the County Juvenile Probation Department. She received her academic training at a junior college, studying social science and psychology. She served as a policewoman in a juvenile division for a number of years and has been with the probation department for 10 years. Approximately 1 to 2 percent of her time is spent on the cases of retarded persons. In county $B$ the application for admission is handled initially by the Hospital Outpatient Services Division, which is located at the county seat. The probation officer becomes involved only after the hospital has set a proposed date of admission. Establishing contact with the family to arrange for an interview, she imstructs each parent to bring his social security number and an estimate of his yearly income tax or some other evidence of his financial condition. This agent uses the interview to accoinplish four things: to determine whether the parents are able to pay the $\$ 20$ per month fee otherwise payable by the county; to have them sign the commitment petition; to determine whether the child can be brought into the courtroom or should be seen by the judge in private; and to describe the court procedure. Her second and final contact with the family is at the hearing.

County $C$. The county $C$ agent is a psychiatric social worker at a children's psychiatric clinic. She has worked with the Family Service Agency's public assistance programs and has been with the clinic for several years. Approximately one-half of her time is spent on hospital 
admissions and the other half is used to diagnose emotional problems in children. The purpose of her first interview with the family, which lasts approximately one and a quarter hours, is to discuss problems that have arisen, to explore whether an alternative placement is possible, to alleviate current stress, and to give the parents an application form to be filled out at home. When the parents return the application form, the agent discusses the court procedure with them. The court clerk meets the parents at the hearing and sees that the case is properly presented to the court. At the time this hospital agent was originally interviewed, she had never attended a court hearing (she later attended a hearing with the interviewer).

County $D$. In this county, the agent is a probation officer whose other duties mclude handling intake interviews in juvenile delinquency cases. He has completed three years of study at one of the California state colleges; his work experience includes nine years as a police officer. He handles both applications for hospital admission and courtcommitment procedures and estimates spending nearly 25 percent of his working time with the mentally retarded.

This agent normally sees the parents at least three times, but sees the retarded person only at the court hearing. At the first interview he learns about the family situation and explains the alternative methods of voluntary admission and court commitment. He does not attempt to influence the parents' choice between these alternatives unless their child is over 16, the age at which the hospital prefers court commitment. He indicates that, if voluntary admission is chosen, the parents will have the responsibility of returning the child to the county for court commitment when lie becomes 21 . This initial interview lasts about 30 minutes and, at its conclusion, the parents are given the hospital application form to take home and fill out. The second interview occurs when the parents return the application form, usually about one month later. The agent goes over the form with them and helps thein with difficult questions. The form, along with all existing medical documents, is mailed to the hospital, and a date is set by the hospital for the preadmission examination.

This agent normally does not see the parents during the waiting period for admission unless unusual circumstances require it ("I usually advise them initially, if the situation deteriorates, to get in touch with me, and we'll see if we can expedite the process a little bit"). After he is notified that an admission date lias been set, the agent sees the parents to get the petition signed and to attend the court hearing, if a commitment is to be made. This agent accompanies the parents and the retarded person to court, presents the case, and may personally deliver the retardate to the hospital. He visits the hospital approximately every three months ("to keep channels of cominunication open"). 


\section{The Commitment Hearing}

The courtroom procedure in commitment cases is determined largely by judicial discretion and, in many counties, is the result of practices established by the local hospital agent and concurred in by the judge. The relevant provisions of the Welfare and Institutions Code afford at best only a general guideline. As we have seen, since 1887 the code has directed the judge to "inquire into the condition or status" of the alleged mentally retarded person before inaking a commitment order. ${ }^{84}$ The judge is further instructed to hold a hearing "at any time and place which the court deems proper, and which will give opportunity for the production and examination of witnesses." hearing must be given to the alleged mentally retarded person, ${ }^{86}$ and the court has authority to subpoena medical witnesses and other persons "as it deems advisable, to give evidence."

The 47 judges who participated in this study were asked how they had learned the commitment procedure when first assigued to preside over these hearings. Of the 44 who responded to the question, 26 indicated that they had learned the procedure from talking to the hospital agent and reading the code provisions, eight had learned from other judges who had previously held the assignment, five had figured it out for themselves, three had known about the procedure in their prior capacity as district attorneys, one learned from his court clerk, and one learned from the district attorney.

As table 2 indicates, judges' other assignments are an important factor in determining where commitment hearings are held. In the large California counties, judges of the superior court are assigned to particular duties annually on a rotating basis by the presiding judge, with seniority pcrmitting some choice. Since the commitment of mentally retarded persons to state hospitals occupies only a tiny percentage of a judge's time, ${ }^{88}$ all the judges who presided over commitments at the time of the study had additional assignments as well. How the assignments were paired varied from county to county. In 13 counties, mental retardation commitments were assigned to the judge who presided over the commitments of the mentally ill (the psychiatric cal-

84. See text following note 23 supra. The requirement is presently found in CAL. ANN. Welf. \& INST'NS Code $\$ 6507$ (West Supp. 1971). After July 1, 1971, the court will also be required to find that the mentally retarded person "is a danger to himself or others" as a prerequisite to the commitment order. Id. $\$ 6500.1$ (West Supp. 1971). See note 92 infra.

85. Id. § 6503 (West Supp. 1971).

86. Id. $\S 6504$.

87. Id. $\$ 6507$.

88. Of the 38 judges who responded to this question, 36 said commitment cases occupied less than 1 percent of their time. The other two judges estimated that less than 5 percent of their time was spent on these cases. 
Table 2. Place of Hearing by Judicial Assignment.

\begin{tabular}{|c|c|c|c|c|c|}
\hline \multirow[b]{2}{*}{ Judge's Other Assignment } & \multicolumn{5}{|c|}{ Place of Hearing } \\
\hline & 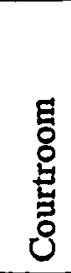 & 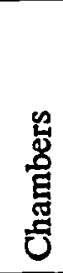 & 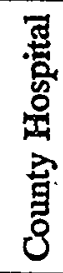 & 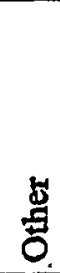 & 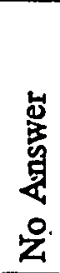 \\
\hline Psychiatric & 2 & 0 & 8 & 1 & 2 \\
\hline Juvenile & 4 & 6 & 0 & 0 & 1 \\
\hline 1-2 Judge County (18) & 7 & 7 & 0 & 2 & 2 \\
\hline Presiding Judge (2) & 0 & 1 & 0 & 0 & 1 \\
\hline Other & 1 & 0 & 0 & 1 & 1 \\
\hline Totals: & 14 & 14 & 8 & 4 & 7 \\
\hline
\end{tabular}

endar); in 11 counties, mental retardation commitments were assigned to the juvenile court judge, who deals with children deemed to be dependent, neglected, or delinquent (the juvenile calendar). In 14 less populous counties, the superior court has only one judge, who must handle all the court's business, including mental retardation commitments. In four other counties, two judges are available, but the division of tasks between them is an informal one. In two counties the presiding judge, who has the job of adininistering the court, handles the mental retardation commitments. Finally, in the three counties grouped in table 2 as "other" counties, one judge sits on both the juvenile and psychiatric calendars, a second hears criminal cases, and in the third county, an ad hoc assignment is made for each mental retardation case as it arises.

As table 2 indicates, all eight counties in which commitment hearings for the mentally retarded are held at the county hospital are counties in which the committing judge also is assigned to the psychiatric calendar. Since the mentally ill are frequently placed in a county hospital pending their commitment to a state hospital, the hearings in their cases are usually held at the hospital to avoid the need of bringing them into the courthouse. Although the mentally retarded are normally hving at home or in a private facility pending their admission to a state hospital, in those eight counties they are asked to report to the county hospital for their hearings as well. In no other county are those hearings held at the county hospital, which suggests that the place of hearing is selected because of the court's convenience rather than because of any special needs of the mentally retarded. Two judges in other counties who handle the psychiatric calendar nevertheless hold the coin- 
mitment hearings for the mentally retarded in the courtroom, indicating that, at least in those cases, a conscious policy clioice is being inade. The split between the use of the courtroom or the less formal judicial cliambers depicted in table 2 is significant because the informality of a hearing in cliambers often means that no court reporter will be present to transcribe the proceedings, as shown in table 3.

Table 3. Place of Hearing by Presence of Court Reporter.

\begin{tabular}{|cc|c|c|}
\hline \multirow{2}{*}{ Place of Hearing } & & \multicolumn{2}{|c|}{ Reporter Present } \\
\cline { 3 - 4 } & & Yes & No \\
\hline Chambers & $(12)$ & 4 & 8 \\
Courtroom & $(11)$ & 8 & 3 \\
County Hospital & $(6)$ & 5 & 1 \\
Other & $(3)$ & 1 & 2 \\
\hline Totals: & 32 & 18 & 14 \\
\hline
\end{tabular}

The judges were also questioned about commitment hearing procedures and about the persons who were customarily present. As we have already seen, in each county either the hospital agent, a court clerk, or the district attorney was present at the hearing to present the petition to the judge and was prepared to make a showing that the person to be committed was actually mentally retarded. In each case, the hospital had already accepted the alleged mentally retarded person as a patient suitable for hospital care. Under these circumstances, the hearing tended to be brief and often seemed perfunctory to the parents. Table 4 shows the estimated length of the commitment hearing: in 32 counties, the judges estimated that each hearing took, at most, 15 minutes. Only seven judges reported hearings that lasted longer than 15 minutes.

Table 4. Estimated Average Length of Hearing in 47 Counties.

\begin{tabular}{c|c|c|c|c|c}
\hline $\begin{array}{c}5 \text { minutes } \\
\text { or less }\end{array}$ & $\begin{array}{c}5-10 \\
\text { minutes }\end{array}$ & $\begin{array}{c}10-15 \\
\text { minutes }\end{array}$ & $\begin{array}{c}15-20 \\
\text { minutes }\end{array}$ & $\begin{array}{c}\text { Over 20 } \\
\text { minutes }\end{array}$ & $\begin{array}{c}\text { No } \\
\text { answer }\end{array}$ \\
\hline 11 & 13 & 8 & 4 & 3 & 8 \\
\hline
\end{tabular}

As table 5 shows, 33 judges indicated that the alleged mentally retarded person was routimely present for his commitment hearing, and four others reported that he was present occasionally. Eight judges reported that the alleged retardate was never present at his commitment hearing. Practice varied as to whether the judges attempted to question the alleged mentally retarded person. Fifteen judges did not ask him questions, while 13 attempted to do so and six others did so if he seemed capable of responding. The court asked both parents to be present at the hearing in 26 counties; there was a division of practice 
as to whether the parents were asked to testify. Whether other witnesses were present was also not uniform: 20 counties reported having other witnesses present, usually medical witnesses, and 14 did not normally have other witnesses. A high degree of uniformity existed, however, on the presence or absence of attorneys at commitment hearings. Thirty-eight of the 40 judges who responded to the question said that counsel was never present. Moreover, although the judges were divided on whether they advised the mentally retarded person or his family of their right to be represented by counsel, 33 of the 41 who answered the question indicated their belief that counsel would not be appropriate or useful at the hearings.

Table 5. Persons Present and Testimony at Hearing.

\begin{tabular}{lr|rcc}
\hline & Yes & No & Occasionally| & No answer \\
\cline { 2 - 5 } 1. Both parents present? & 26 & 3 & 1 & 17 \\
2. Parents testify? & 17 & 11 & 0 & 19 \\
3. Alleged retardate present? & 33 & 8 & 4 & 2 \\
4. Judge question retardate? & 13 & 15 & 6 & 13 \\
5. Witnesses (other than agent) & & & & \\
$\quad$ present? & 14 & 20 & 0 & 13 \\
6. Is counsel present? & 2 & 38 & 0 & 7 \\
7. Judge advise of right to counsel? & 13 & 21 & 0 & 13 \\
8. Judge think counsel appropriate? & 8 & 33 & 0 & 6 \\
\hline
\end{tabular}

The judges' responses to questions about the dispositional alternatives available to them at the commitment hearing made clear that no alternative placement was discussed at the hearing. The legal issue before the court is not the abstract question of placement of an allegedly mentally retarded person but rather whether the person shall be committed to the Department of Mental Hygiene for placement in a particular state hospital. As table 6 shows, although 36 judges said they felt free to refuse the commitment order, none stated that they had ever done so. Twenty-two judges thought they had authority to place the mentally retarded person in another facility; of the nine who felt they could not choose another placement, five stated that no alternative facilities were available for thein to choose. The real point seems to lie in the last two questions: 42 of the judges had never seen a contested commitment case and only eight made any attempt to discover whether the parents were experiencing conflict about their decision to place their mentally retarded child in the hospital. As one judge expressed it, "There's no conflict in the evidence in these cases-it's all one-sided." 
Table 6. Dispositional Alternatives.

1. Free to refuse commitment?

2. Could you make alternative placement?

3. Have you ever refused to commit?

4. Do you examine parents for conflict?

5. Seen a contested commitment case?

\begin{tabular}{c|c|c} 
Yes & No & No answer \\
\hline 36 & 4 & 7 \\
22 & 9 & 16 \\
0 & 24 & 23 \\
8 & 25 & 14 \\
2 & 42 & 3 \\
\hline
\end{tabular}

Each judge was asked to choose from a suggested list the factors that influenced his decision to commit. The list contained 10 items, including one that allowed the judge to state any other factor that influenced his decision. No judge listed any other factor. One factor, the cost to the community of maintaining the retarded person outside the hospital, was not chosen by any judge. The remaining eight factors, collapsed into six for reporting purposes, ${ }^{89}$ are listed in table 7. Although the judges were asked to rank the factors in their order of importance, not enough judges did so to make separate reporting worthwhile. Table 7 shows only the number of times each factor was chosen by the 32 judges who responded to this question. The table indicates that more judges relied on the hospital's decision to accept the mentally retarded person as a patient than on any other factor. The second factor chosen most frequently is the appearance of the mentally retarded person. Although most of the judges recognize their inability to diagnose a person as mentally retarded with a glance, some judges found reassuring confirmation of the medical diagnosis in the physical appearance of the more profoundly retarded persons. The remaining three factors most frequently chosen-information provided by the hospital agent, testimony of the parents, and medical witnesses-all tend to reinforce the hospital's decision to accept the person to be committed. Thus, the factors that are seen by the judges as important are consistent with the point made in discussing table 6: all the evidence presented at the commitment hearings of the mentally retarded supports the result of commitment. ${ }^{90}$

89. The 10 factors were: (1) the hospital's decision to accept the child; (2) information given by hospital agent; (3) testimony of the parties (parents); (4) testimony of inedical witnesses; (5) appearance of the child; (6) cost to the community; (7) extent of retardation reported; (8) danger to society; (9) danger to self; and (10) other. Item 7, extent of retardation reported, was collapsed into item 2, information given by hospital agent, smce that person was usually the source of such information. Items 8 and 9 were put together and appear as itein 6 in table 7 .

90. The effect of the requirement in effect since July 1, 1971, that no person be judicially committed unless he is a danger to himself or others is discussed in the text accompanying notes $277-327$ infra. 
Table 7. Factors Influencing Judicial Decision to Commit (32 Judges).

\begin{tabular}{|l|r|}
\hline 1. Hospital's Decision to Accept & 22 \\
2. Information Given by Hospital Agent & 10 \\
3. Testimony of Parents & 10 \\
4. Testimony of Medical Witnesses & 8 \\
5. Appearance of Mentally Retarded Person & 14 \\
6. Danger of Person to Himself or Society & 3 \\
7. No answer & 15 \\
\hline
\end{tabular}

After the details of the commitment procedure had been elicited, the judges were asked for a broader evaluation of the legal process of commitment. They were asked to evaluate the part they, as judges, played in the commitment hearings: Did they decide the merits of the case in these proceedings as they were commonly expected to do in other legal proceedings? Did they, as judges, feel comfortable in their role in these cases? And did they think the court should be involved in the process of hospital admission? The judges' answers to these questions are shown in table 8 . Although a significant number (32 of 47) of judges expressed a feeling of comfort in their role in these cases and thought the court should be involved, 25 of the judges (a shight majority) stated that they did not make the actual decision to commit the alleged retarded person to the hospital.

Table 8. Judges' Evaluation of Role in Commitment Cases.

\begin{tabular}{|l|c|c|c|}
\hline & Yes & No & No answer \\
\hline 1. Make actual decisions? & 19 & 25 & 3 \\
2. Feel comfortable in role? & 32 & 8 & 7 \\
3. Should court be involved? & 32 & 8 & 7 \\
\hline
\end{tabular}

Following up on their role evaluations, the judges were next asked how they viewed their function in these cases. As table 9 shows, 25 of the judges saw themselves as a rubberstamp, having the sole function of adding the force of law to a decision already made by others, primarily the hospital. Twelve judges saw their function according to traditional judicial ideals: as a guardian of the due process rights of the alleged mentally retarded person, preventing the retardate from being "railroaded" into the institution. A smaller number of judges-six of the 47-felt that their function was to provide therapy for the parents of the retarded person, reassuring them by the very formality of the legal procedure that they had made the right decision. ${ }^{01}$

91. This view most nearly coincides with the justification for commitment given by the Superintendent then at Sonoma: that the court proceeding helps lessen parental guilt. See text accompanying note 65 supra. 
Table 9. Judge's Self-Image in Commitment Cases.

\begin{tabular}{|l|r|} 
1. Rubberstamp for Others' Decision & 25 \\
2. Guardian of Due Process for Retardate & 12 \\
3. Afforder of Therapy for Parents & 6 \\
4. No Answer & 4 \\
\hline
\end{tabular}

Table 10 analyzes the responses reported in tables 8 and 9. It indicates, consistently enough, that 22 of the 25 judges who viewed themselves as rubberstamps for the hospital's decision felt that they do not themselves decide the merits of the case. The 12 judges who believed that they play a significant part in these proceedings as the guarantor of due process for the retardate all indicated that they do actually decide the cases. The six judges who saw their function as providing therapy for the parents were divided: four thought they do make the decision, while one did not think so and the sixth failed to respond to this question.

Interestingly enough, 15 of the 25 judges who saw themselves as rubberstamps nevertheless believed that the court should be involved in the hospital admission process. Only one judge who believed he helped guard the due process rights of the retardate thought that the court should not be involved in these proceedings. Three of the six judges who were oriented to providing therapy for the parents felt that this function was properly one to be performed by the court and that the court should continue to be involved.

Table 10. Iudges' Self-Image by Evaluation of Role.

\begin{tabular}{|c|c|c|c|c|c|c|c|c|c|c|}
\hline & \multicolumn{3}{|c|}{ Court Involved? } & \multicolumn{3}{|c|}{ Make Decision? } & \multicolumn{3}{|c|}{ Comfortable? } \\
\hline & & Yes & No & No answer & Yes & No & No answer & Yes & No & No answer \\
\hline Rubberstamp (2 & (25) & 15 & 7 & 3 & 2 & 22 & 1 & 17 & 5 & 3 \\
\hline Due Process (1 & (12) & 10 & 1 & 1 & 12 & 0 & 0 & 8 & 1 & 3 \\
\hline Therapy & (6) & 3 & 0 & 3 & 4 & 1 & 1 & 5 & 0 & 1 \\
\hline Totals: & 43 & 28 & 8 & 7 & 18 & 23 & 2 & 30 & 6 & 7 \\
\hline
\end{tabular}

\section{Discussion}

These descriptions of the role and function of the hospital agent in the commitment process and of the commitment hearing itself prior to 1971 combine to produce an image of a legal procedure that was marginal at best. Except in a relatively few cases involving retarded children who had been brought within the jurisdiction of the juvenile court, the parent or guardian of the retarded person was the petitioner who sought commitment. As we lrave seen, this person filled out an application for admission to the hospital and usually took the retarded person there for a preadmission examination. If the retardate was found to be eligible and suitable for admission, a waiting period fol- 
lowed until hospital space was available. It was only after the hospital notified the parent, usually through its community agent, that a bed was available for the retardate, that the superior court judge was called upon to play a part in the admission process.

In 46 counties, a probation officer handled the court-commitment phase of the admission process. If an individual was to be court-committed, the hospital notified the probation officer of the admission date and sent him the petition forms for his preparation. This task took little time as the form was brief and the allegations standard. In the space for "petitioner's reasons for supposing said person to be eligible to a state hospital," the probation officer noted the prior acceptance by the hospital. He may also have included a phrase from the medical report. A parent then signed the petition, and it was filed with the court clerk.

Twenty-nine probation officers and three nonprobation agents believed the court commitment process was necessary: some thought it was required by law; others knew that the alternative of voluntary admission existed, but agreed with their hospital's policy of requiring commitments in the cases where that policy existed. Only 10 probation officers and one nonprobation agent said that the commitment procedure was unnecessary.

The court was directed to "inquire into the condition or status of the alleged mentally deficient person." to be mentally deficient, it could make the order for commitment. In addition, the probation officer furnished the court with information concerning the financial status of the parent. If the court found the petitioner able to make a nominal monthly payment of $\$ 20$ to the county for the maintenance of the mentally deficient person, it made a financial order. ${ }^{93}$ The county was responsible to the State Department of Mental Hygiene for this amount, whether or not it could be collected from the petitioner. ${ }^{94}$

The reaction of judges to this procedure was exemplified in the way they defined their participation $\mathrm{m}$ the court hearing. ${ }^{05}$ In broad terms, three self-images were discernable: the 43 judges who responded to the question saw themselves either as rubberstamps, as therapeutic agents for the families, or as the legal protector of the retarded person's

92. See note 84 supra. In 1970 , the legislature added the requirement (to be effective July 1,1971 ) that "no mentally retarded person may be committed to the Department of Mental Hygiene . . unless he is a danger to himself or others." CAL. ANN. Welf. \& INST'NS CODE $\$ 6500.1$ (West Supp. 1971). The new requirement is discussed at text accompanying notes 277-327 infra.

93. Cal. ANN. Welf. \& INST'NS Code \& 6715 (West Supp. 1971).

94. Id. \$§ 7510-11. See generally Knudsen, Mental Retardation-Who Should Pay the Bill for Residential Care in Public Institutions?, 3 FamILY L.Q. 331 (1969).

95. See tables 8-10. 
due process rights. The California statutes do not authorize judges to commit directly to a state hospital for the mentally retarded an individual they beheve is im need of its care. ${ }^{96}$ Instead, the code allows the hospital to control admissions. ${ }^{97}$ Because of the statutorily imposed necessity of securing prior acceptance from the hospital, 25 judges defined their roles as mere rubberstamps and referred to their hearings as redtape administrative formality. At least three judges held the commitment hearing with neither the parent nor the retardate present. ${ }^{98}$ One judge reported that the probation officer, who functions as the hospital agent in the county, "fills me in" on the situation: after discussion between the two of them, the judge signed the order. Another judge, who did not see any of the retarded persons whose cases arose on a given day, admitted all their parents at once into his hearing room. $\mathrm{He}$ recognized that this lack of privacy made the parents reluctant to talk, but, he said that "talk is unnecessary anyway."

It is apparent that many of the judges disliked conducting a proceeding that left so little room for imagination and the exercise of customary discretion. While they did not deny the pro forma nature of the proceeding, some of them embellished these hearings with many of the procedures that had become familiar to them in commitment hearings for the mentally ill. Consequently, some of the same abuses could be recognized in both proceedings. The hearings rarely lasted more than 5 or 10 minutes. $^{99}$ While a few judges felt compelled to inform the parents of their right to counsel " $m$ the light of recent Supreme Court decisions," the vast majority thought that an attorney was not only unnecessary but also inappropriate. ${ }^{100}$ "After all," remarked one judge, "the parents initiated the petition, and if they know what they are doing and are domg it of their own volition, then what need is there for legal advocacy in a nonadversary proceeding?" In some counties, the mental deficiency petitions were heard at the county hospital either prior to or following the mental illness petitions. ${ }^{101}$ Thus, the county medical examiners, whose primary function was to examine the mentally ill, were often available to look at the retarded individuals in a cursory way and report their findings to the judge. In addition, the parents inight make a brief statenent, ususally unsworn, and the local agent might make a recommendation for commitment based on the hospital's

96. CaL. ANN. Welf. \& INST'NS CODE $\$ 6509$ (West Supp. 1971).

97. Id.

98. See table 5. The three counties where no parents were present did not have the alleged retardate present either.

99. See table 4. See also Weihofen and Overholser, Commitment of the Mentally Ill, 24 Texas L. REv. 307, 324-25 (1946).

100. See table 5 .

101. See table 2 . 
acceptance of the individual. Given the casual nature of the proceedings, it is not surprising that the presence of the court reporter to record these statements was often dispensed with as unnecessary. ${ }^{102}$

Six of the judges defined their role in the commitment process as that of providing therapy for the families of the retarded. ${ }^{103}$ Like the first group of judges, these also recognized the essential rubberstamp nature of the proceedings, but instead of taking refuge in legal ritual and maintaining a certain aloofness they chose to use the legal procedure to alleviate parental distress. The judges who regarded therapy as a valid function of the hearing usually asked few questions of the parents, hesitating to cause any emotional breakdown in the courtroom. A few judges intentionally prolonged the length of the courtroom ritual so the parents would not feel that they were being put through an assembly line operation. Even the cursory examination by the medical examiners and their subsequent report to the court was seen by these judges as being therapeutically useful. They believed that hearing another confirmation of their child's affliction helps the parents to erase all doubts before the commitment is formally and finally made.

Twelve judges defined their role in the commitment process in the traditional terms of providing "fair play and substantial justice," of "giving everyone his day im court," of receiving and weighing evidence, and of making a decision based on the evidence. ${ }^{104}$ Although these are acceptable judicial functions, whether procedural due process was satisfied in these cases must be examined more closely. A few judges believed that due process meant a fair hearing, not for the mentally deficient individual, but for other parties who might be interested in contesting the commitment. The image of the retarded person as one who is incapable of functioning in society and not being capable of exercising legal rights permeated the hearing and appeared to color the judge's conception of what due process required. Specifically, although ordinarily a judge would refuse to decide the case of an absent defendant, he might feel no qualms about depriving a retarded imdividual of his liberty even though that individual was neither present nor effectively represented in court. While all the judges who were interviewed stressed that they possessed the power to deny a commitment, they were virtually unanimous in predicting the near-impossibility of such a situation. None of the judges reported ever having refused a commitment. ${ }^{105}$ Because of the vigorous preadmission screening by the hospitals, and because of the extreme scarcity of hospital space, the judges

102. See table 3.

103. See table 9.

104. Id.

105. See table 6. 
believe that only the most severely retarded individuals were being accepted by the hospitals, which helped them to feel secure in their decisions.

The field study indicates that mental retardation commitments are marginally legal cases and that they occupy only a small part of the court's workload. Because these cases were seen as being outside the normal court business, great rehance was placed on outsiders, such as the hospital and its community agents, to carry the burden of responsibility the commitments represented. As far as the judges were concerned, these were cases without contest and characterized by unconflicting evidence. As one of our informants said, "It all points toward hospitalization."

\section{Legal Implications of Commitment}

The judges were asked questions designed to ehicit their views of the legal effect of the commitment orders they signed. Specifically, they were asked whether the effect of the commitment order was to render the person committed legally incompetent, whether committed persons retained, for exainple, the power to make contracts or to marry, and finally, whether, in their view, the commitment order was of lifetime duration. The responses to these questions are shown in table 11.

Table 11. Judges' Views of Legal Effect of Commitment.

\begin{tabular}{l|r|c|c|c}
\hline & Yes & No & $\begin{array}{c}\text { Don’t } \\
\text { know }\end{array}$ & $\begin{array}{c}\text { No } \\
\text { answer }\end{array}$ \\
\hline 1. Person legally incompetent? & 18 & 7 & 12 & 10 \\
2. Can he contract? & 4 & 7 & 20 & 16 \\
3. Can he marry? & 6 & 5 & 20 & 16 \\
4. Is commitment for life? & 18 & 11 & 0 & 18 \\
\hline
\end{tabular}

These responses indicate the judges' uncertainty about the legal effect of their orders. The reactions of some judges to these questions during personal interviews ${ }^{106}$ indicated that their perceptions of the mentally retarded as essentially without rights affected not only their view of what due process safeguards are required at the commitment hearing but also their opinion about the legal disability and stigma resulting from the commitment order. One interviewer felt that many judges thought it ridiculous and purely speculative to consider what legal rights might be lost through commitunent. As table 11 indicates, 18 judges beheved their commitment orders had the legal effect of a life sentence.

106. See text following note 104 supra. 
Eleven other judges believed that commitment was of indeterminate duration, depending on the hospital policy and the patient's progress. This view seems more nearly in accord with actual practice. The medical director of a state hospital has authority to grant a leave of absence to a mentally retarded patient under conditions prescribed by the Department of Mental Hygiene. ${ }^{107}$ Patients on leave may, however, be recalled by the hospital. ${ }^{108}$ And, although no mentally retarded patient in a state hospital may be transferred to another state hospital without the consent of his parent or guardian, if any, ${ }^{109}$ the hospitals may and do place their patients in foster homes, sheltered workshops, or other community facilities without parental consent. Moreover, if a parent asks that his retarded child be returned home, the hospital normally complies. According to the hospital superintendents, the implied authority, conferred by the commitment order, to retain the retarded person as against his parents' wish to have him returned, is rarely used. Thus, the difference in practice between voluntary and committed patients is an obscure one.

The judges' uncertainty as to the legal effect of commitment orders hospitalizing the mentally retarded upon their general legal competence is not surprising in view of a similar lack of clarity existing ainong legal scholars. A 1961 study, dealing primarily with the mentally ill, documented the variety of state laws covering this matter and the general confusion as to the impact of hospitalization commitment orders on the legal competence of the mentally ill. ${ }^{110}$ Since 1961, studies in several states have documented the impact of civil commitment orders on the legal rights of the mentally disordered, ${ }^{111}$ but without always maintaining a clear distinction between the mentally ill and the mentally retarded. A major job of clarification was recently presented in the Mental Competency Study, ${ }^{112}$ which notes that Cahifornia is one of a group of states in which the issues of incompetence and hospitalization are theoretically kept separate for both the mentally ill and the mentally retarded. ${ }^{113}$

In California, the problem has recently been complicated for the mentally retarded by a new law that became effective after the Mental

107. CAX. ANN. Welf. \& INST'NS CODE $\$ 7352$ (West Supp. 1971).

108. Id. § 7351. See text accompanying notes $254,260-61$ infra.

109. Id. \& 7305; see also id. § 7514.

110. F. Lindman \& D. Mcintrre, The Mentally Disabled and the Law 219-25 (1961) [heremafter cited as LINDMAN].

111. E.g., Dewey, Civil Incompetency in Ohio, 34 U. CINN. L. Rev. 419 (1965); Ely, The Status of Mental Incompetents in Civil Cases in Missouri, 33 Mo. L. Rev. 1 (1968); Gimsberg, Civil Rights of the Mentally Disabled in Oklahoma, 20 OкL . I. Rev. 117 (1967); Zenoff, Civil Incompetency in the District of Columbia, 32 Gzo. WASH. L. REV. 243 (1963).

112. AlLEN, supra note 53, at 46-68.

113. Id. at 50. 
Competency Study was published. In 1967, the California legislature undertook a thoroughgoing revision of the law dealing with civil commitment of the mentally ill. The product of a two-year study, ${ }^{114}$ the Lanterman-Petris-Short Act became effective on July 1, 1969. ${ }^{115}$ In general, the Act repealed the old judicial indeterminate commitment, removed the legal disabilities formerly miposed upon the mentally ill, and created an extensive program of community-based services that emphasized voluntary treatment but provided for short periods of involuntary observation and crisis treatment (for those who are so gravely disabled as a result of mental disorder as to be unable to care for themselves or whose condition makes them a danger to themselves or others). A constitutional challenge to the new law, raised shortly after it became operative, was averted by statutory amendment ${ }^{116}$ and by a court opinion authorizing procedures in aid of the patient's right to secure a hearing during the 14-day involuntary intensive treatment period. ${ }^{117}$

The Lanterman-Petris-Short Act expressly states that no person may be presumed to be incompetent because he has been "evaluated or treated for mental disorder or chronic alcohohsm, regardless of whether such treatment or evaluation was voluntarily or involuntarily received."118 Persons leaving public or private mental health facilities following evaluation or treatment for mental disorder or chronic alcohohsm are entitled to a (presumably written) statement of California law on this point. ${ }^{119}$ This section, like all other provisions of the Act, does not repeal or modify laws relating to the commitment of the nientally retarded. ${ }^{120}$ And former Welfare and Institutions Code section 6729 , which had provided for certificates of competence and which was

114. Subcomm. on Mental Health Services of the Cal. Assembly Interim Comm. on Ways and Means, The Dilemma of Mental Commtments in CalIFORNIA: A BACRgROUND DOCUMENT (Nov, 1966) [hereinafter cited as A BACKGROUND Documenr]. See also Project, Civil Commitment of the Mentally Ill, 14 U.C.L.A.L. Rev. 822 (1967) (reporting on practices in Los Angeles County); Note, The Need for Reform in the California Civil Commitment Procedure, 19 StAN. L. Rev. 992 (1967) (reporting on practices in San Francisco County).

115. Cal. ANN. Welf. \& INst'Ns COde $\S \S 5000-5401$ (West Supp. 1971). The Act is discussed in Comment, Civil Commitment of the Mentally Ill in California: 1969 Style, 10 Santa Clara Law. 74 (1969).

116. Ch. 722, §§ 11.1, 11.2, [1969] Cal. Stat. 1416 (amending section 5252 and adding section 5252.1, providing for notification of the right to counsel and the availability of habeas corpus).

117. Thorn v. Superior Court, 1 Cal. 3d 666, 464 P.2d 56, 83 Cal. Rptr. 600 (1970); see also County of San Diego v. Superior Court, 1 Cal. 3d 677, 464 P.2d 63, 83 Cal. Rptr. 607 (1970) (companion case to Thorn).

118. CAL. ANN. WelF. \& INST'NS CODE $\$ 5331$ (West Supp. 1971).

119. Id.

120. Id. \$ 5002. See also id. $\$ 5008(\mathrm{~h})$ : “A person of any age may be 'gravely disabled' under this definition, but the term does not include mentally retarded persons." 
interpreted by the Mental Competency Study as applying to the mentally retarded as well as the mentally ill, ${ }^{121}$ was repealed by the new law. ${ }^{122}$ The result is that no express statutory authority exists either to determine the effect of civil commitment upon the legal competence of the mentally retarded or to provide for their restoration to competence following commitment. For this reason, some of the judges interviewed expressed the belief that the legislature did not contemplate that restoration proceedings were appropriate for the mentally retarded, due to the intractable nature of their disability.

The background study prepared for the legislature during its work on the Lanterman-Petris-Short Act contained an appendix comparing the disabilities resulting from involuntary commitment to a mental institution, voluntary admission to mental institutions, and conviction of a felony. ${ }^{123}$ One item in that appendix is a list of approximately 25 businesses or professions in which commitment operated as an automatic suspension of the person's right to practice. The Act made a point of repealing most of those provisions. ${ }^{124}$ Similar provisions in the Elections Code suspending the committed person's right to vote until he was restored to competence ${ }^{125}$ were also repealed. ${ }^{126}$ Most of the repealed sections restricting the right to practice a business or profession applied more clearly to the mentally ill than to the mentally retarded. A common phrasing stated that

the adjudication of imsanity or mental illness, or the voluntary commitment or admission to a state hospital for a mental illness shall operate as a suspension of the right to practice of any certificate or permit holder under this chapter, such suspension to continue until restoration to or declaration of sanity or mental competence. ${ }^{127}$

121. ALLEN 57 n.55. It is not obvious that former section 6729 [Welf. \& Inst'ns Code of $1937 \S 6729$, [1937] Cal. Stat. at 1161 (repealed 1969)] was ever intended to apply to the mentally retarded. It is true, as the Mental Competency Study notes [see note 53 supra], that the first sentence of section 6729 stated that the certificate of competency was available to "any person released from a state hospital," but the statutes at that time distinguished "state hospitals for the care and treatment of the insane, the mentally ill, and the mentally disordered" [former Welf. \& Inst'ns Code $\$ 6500$, now renumbered CAL. WelF. \& INST'NS CODE $\$ 7200$ (West Supp. 1971) and called "statc hospitals for the care and treatment of the mentally disordered"] from "state hospitals for the care and treatment of the mentally deficient" [former $\$ 7000$, now renumbered CAL. WELF. \& INST'NS CODE $\$ 7500$ (West Supp. 1971) and called "state hospitals for the care and treatment of the mentally retarded"]. Moreover, section 6729 was in chapter 1 ("State Hospitals for the Mentally IIl") not chapter 3 ("State Hospitals for the Mentally Deficient").

122. Former section 6729 was repealed by ch. 1667 , $\$ 36.5$, [1967] Cal. Stat. 4053, 4107 (effective July 1, 1969).

123. A BACKGROUND DocumeNT, app. Table V, at 188.

124. Ch. 1667, §§ 1-29, [1967] Cal. Stat. 4053.

125. Former Elections Code $\S \S 388,388.2,388.4,388.6$.

126. Ch. 1667, §§ 31-34, [1967] Cal. Stat. 4055.

127. Ch. 1803, § 13, [1955] Cal. Stat. 3341 (former Bus. \& Prof. Code § 5107). 
Accordingly, the repeal of these sections probably does not bear on the legal competence of mentally retarded persons who have been committed to hospitals. Nor is it clear that the voting sections applied to the mentally retarded. Section 388 of the Elections Code apparently applied to the retarded only if a guardian had been appointed, ${ }^{128}$ a practice not normally accompanying the hospital commitment order. ${ }^{129}$

Other provisions listed in the "appendix of disabilities" that depended on the individual's ability rather than a court order were not changed by the new Act. Thus, the Department of Motor Vehicles is instructed by statute not to issue or renew the driver's license of a person who is insane, feebleminded, an idiot, or an imbecile..$^{130}$ These sections were not altered. The beneficial impact of the Lanterman-PetrisShort Act, then, seems primarily limited to the mentally ill and not applicable to the mentally retarded.

The basic problem of the effect of commitment on the legal competence of the mentally retarded in California is further compounded by the similarities of concept between the legal definitions of "mental retardation" and "mental imcompetence": the commitment section of the Welfare and Institutions Code defines the mentally retarded as

those persons, not psychotic, who are so mentally retarded from infancy or before reaching maturity that they are incapable of managing themselves and their affairs independently, with ordinary prudence, or of being taught to do so, and who require supervision, control, and care, for their own welfare, or for the welfare of others, or for the welfare of the community. ${ }^{131}$

The Probate Code defines an incompetent or mentally incompetent person (for whom a guardian may be appointed) as

any person, whether insane or not, who by reason of old age, disease, weakness of mind, or other cause, is unable, unassisted, properly to manage and take care of himself or his property, and by reason

\footnotetext{
128. Former Elections Code $\$ 388$ provided:

Every judge before whoin proceedings are had which result in any person being declared incapable of managing or taking care of either himself or property or both, and for whom a guardian of his person or estate or both is accordingly appointed, or which result in his being committed to a state hospital as a mentally ill person, shall file with the county clerk a certificate of that fact, and thereupon the county clerk shall cancel the affidavit of registration of that person.
}

Ch. 23, \$ 3, [1961] Cal. Stat. 582, 601 (emphasis added).

129. The Department of Mental Hygiene might seek its appointment after coinmitment as guardian of the patient's property, however, and this subsequent appointment would of course make section 388 operative. See text accompanying notes 133-38 infra.

130. Cal. ANn. Vefucle Code $\$ \$ 12805,13359$ (West 1971).

131. Cal. AnN. Welf. \& INST'Ns Code $\$ 6500$ (West Supp. 1971). 
thereof is likely to be deceived or imposed upon by artful or designing persons. ${ }^{132}$

An order appointing a guardian of the person or estate for an adult has the legal effect of rendering him incompetent to act alone. ${ }^{133}$ The statutory language of the commitment section, read most broadly, could arguably result in merging a finding of imcompetence with the hospitalization order, even though the word "incompetent" does not appear in the section. If this is the result of commitment, the statute is deficient in not appointing a guardian to care for the affairs of the retardate. The parent presumably remains the natural guardian of the person of his committed minor child, but custody of the child's person is transferred by the order to the hospital. If no parent is present or able to serve, even nominally, as guardian of the child's person during his hospitalization, the hospital appears to assume that function, in fact if not in law. Patients who are 18 or older no longer remain under the natural guardianship of their parents; since the Department of Mental Hygiene is not appointed guardian of the person of its patients, these persons lack the protection of guardianship.

The Department of Mental Hygiene is, however, empowered by Welfare and Institutions Code section 7284 to seek court appointment as guardian of the estate of certain of its patients. Section 7284 provides in part that

[i]f any incompetent person, who has no guardian and who has been admitted or committed to the Department of Mental Hygiene for placement in any state hospital for the mentally disordered or the mentally retarded is the owner of any property, the Department of Mental Hygiene, acting through its designated officer, may apply to a court of competent jurisdiction for its appointment as gnardian of the estate of such incompetent person. ${ }^{134}$

Until 1967, when the words "admitted or" were added in the second line, this section, read narrowly, authorized the department to seek appointment only if the patient was incompetent and had been committed to the department by a court order. ${ }^{135}$ Consequently, patients who entered voluntarily or by parental permission were apparently ineligible for this service. Even prior to 1967, however, the department read "committed" broadly to include all forms of admission

132. Cat. ANn. Prob. Code $\$ 1460$ (West Supp. 1971).

133. See generally Note, Contractual Capacity of a Ward, 1967 U. WASH. L.Q. 545.

134. Cal. ANn. Welf. \& INST'Ns Code $\S 7284$ (West Supp. 1971). See text accompanying note 332 infra.

135. Welf. \& Inst'ns Code of $1937 \S 6660$, [19371 Cal. Stat. at 1158, now repealed and reenacted as amended, CAL. ANN. WeLF. \& INST'NS CODE $\$ 7284$ (West Supp. 1971). 
to the hospital and did in fact seek appointment for both committed and voluntary patients. ${ }^{136}$ The 1967 amendment provides statutory authorization for this practice. The necessary proof that the patient is incompetent is supplied by having the lospital superintendent state that the patient for whoin guardianship is recommended is incapable of managing his own affairs. The recommendation is then filed with a superior court exercising probate jurisdiction, accompanied by a verified petition for appointment of the department as guardian of the patient's estate. The petition alleges, in the language of Probate Code section 1460 , that the patient is "unable, unassisted, properly to manage and take care of himself or his property, and by reason thereof is likely to be deceived or imposed upon by artful or designing persons."137 The patient rarely appears at the guardianship hearings; a medical certificate is routinely filed stating that he is unable to attend or that his presence in court would "retard or impair" his recovery or "increase his mental debility." 138

This procedure indicates that the department's administrative interpretation of the commitment section is that the court order of commitment does not itself constitute an adjudication of incompetence sufficient to create legal authority in the department to act as the patient's guardian. On the other hand, the probate court appears willing to accept the fact of hospitalization, whether voluntary or involuntary, plus the superintendent's affidavit that a mentally retarded patient is unable to care for himself, as sufficient proof of incoinpetence to sustain the appointment.

The uncertainty that attends the legal status of the committed mentally retarded patient may extend into many areas of his daily life if he returns to the community. For example, his ability to contract may be questioned. California has three basic code sections dealing with the power to contract. Civil Code section 38 provides that persons "entirely without understanding" lack power to make contracts of any kind. ${ }^{130}$ Civil Code section 39 provides that persons of "unsound mind" who are "not entirely without understanding" may rescind contracts made prior to a judicial determination of incapacity. This progression suggests that the phrase "unsound mind" refers to a less severe handicap than denoted by "entirely without understanding." Civil

136. This description is based on conversations with Mr. Frauk Houston, guardianship officer of the Department of Mental Hygiene.

137. CaI. ANN. Prob. Code \& 1460 (West Supp. 1971).

138. The practice comports with the requirements of $C_{A L}$. ANN. ProB. Code $\S 1461$ (West Supp. 1971).

139. See also CAL. Crv. Code $\$ \S 1556-57$ (West 1970). Several other states have statutes similar to section 38. See Weihofeu, Mental Incompetency to Contract or Convey, 39 S. CaI. L. REv. 211, 216 (1966) [hereinafter cited as Weihofen]. 
Code section 40, in turn, states that a person of unsound mind who has been judicially determined to be incapacitated cannot contract "until his restoration to capacity." Section 40 then provides that a certificate from the superintendent of the "insane asylum to which such person may have been committed" stating that he has been discharged from the asylum "cured and restored to reason" will establish a presumption of legal capacity to contract "from the time of such discharge."140

Several interesting points arise from the interaction of these statutes. In the first place, no further statutory identification of persons "entirely without understanding" is available. It was argued in Estate of Gregorson ${ }^{141}$ that a marriage contracted by a person "entirely without understanding" should be void rather than merely voidable, as is the case when a marriage is contracted by a person of "unsound mind." 142 The California supreme court in Gregorson reserved the issue, ${ }^{143}$ but a district court of appeals rejected the argument 27 years later. ${ }^{144}$ Disagreeing, Professor Barbara Armstrong, a leading authority on California family law, has argued that mnarriages contracted by persons found to be entirely without understanding within the meaning of section 38 are void rather than voidable. ${ }^{145}$ The statutory progression of sections 38 and 39 supports her conclusion.

The decisive issue in the annulment cases, however, is the capacity of the person alleged to have been of unsound mind at the time of the marriage. ${ }^{146}$ In contrast to his total incapacity to contract under section 40, a prior adjudication of incompetence does not prevent the incompetent from subsequently entering a valid marriage, even though he has not been judicially restored to competence at the time of the ceremony. ${ }^{147}$ It would seem to follow that an order of

140. In this connection, the apparent absence of a statutory "certificate of competency" for the retarded is significant. See text accompanying note 119 supra.

141. 160 Cal. 21, 116 P. 60 (1911).

142. CaI. Crv. CoDe $\$ 4425$ (c) (West 1970).

143. $160 \mathrm{Cal}$. at 21, 116 P. at 60.

144. Karau v. Ricketts, 26 Cal. App. 2d 606, 80 P.2d 108 (1st Dist. 1938).

145. She concludes that it is questionable policy to validate the marriage of a person "wholly without understanding" since it might then be impossible to annul the marriage following the death of one of the spouses, just as in the case of marriages of persons of unsound mind. CAL. Crv. CoDE $\$ \S 4425$ (c), 4426(c) (West 1970). The rule would then encourage designing persons to marry those "wholly without understanding" from motives of economic gain. 1 B. ArMstrong, California Family LAw 30 (1953). See'also, id. at 62 where, in commenting on Dunphy v. Dunphy, 161 Cal. 380, 119 P. 512 (1911), Professor Armstrong argues that the annulment of a marriage contracted by a long-term intemperate user of alcoholic beverages might better be placed on the ground that the contracting party was wholly without understanding than that he was of unsound mind.

146. Vitale v. Vitale, 147 Cal. App. 2d 665, 669-70, 305 P.2d 690, 693 (1st Dist. 1957). ("While it is plaintiff's mental condition on that day that is in issue, that condition may be determined from his condition prior and subsequent to the day").

147. Middlecoff v. Middlecoff, 167 Cal. App. 2d 698, 704, 335 P.2d 234, 238 (1st 
commitment would not, of itself, render a mentally retarded person incapable of legally marrying. ${ }^{148}$

In order to have capacity to dispose of property by will, California statutory law requires that a person be over 18 and "of sound mind."149 Case law has generally interpreted this requirement to mean that testamentary capacity exists if, at the time the will is executed, the testatrix is "possessed of sufficient mental capacity to understand her act, to understand and recall the nature and situation of her property, and to remember and understand her relations to persons who have claims upon her bounty and whose imterests are affected by the provisions of the instrument." ${ }^{\prime 150}$ Here, as in the marriage case, the California courts have held that an adjudication of incompetence does not prevent the incompetent froin making a valid will. ${ }^{151}$ Similarly, it has been held that an order of involuntary commitment of a mentally ill person to a hospital does not, of itself, prevent that person froin making a will. ${ }^{162}$ At most, an adjudication of incompetence raises an inference of lack of testamentary capacity upon the date of the adjudication. ${ }^{153}$ Again, it would seein to follow that it is the individual's capacity at the time he performs the act in question that is decisive, rather than the order of commitment. ${ }^{154}$ It has been suggested, however, that since a finding of mental deficiency may indicate an impairment of the individual's capacity to recall the nature and extent of his property and to appreciate the relationship between his property, the disposition he is making of his property, and the natural objects of his bounty, the finding should be strongly probative of a lack of testamentary capacity. ${ }^{155}$ Where business transactions or conveyances of property are concerned, the California courts have subscribed to similarly

Dist. 1959). A "judgment of nullity" is now used in California rather than the old "annulment" [CAL. CIV. CODE $\S 4450$ (West 1970)], but a party's "unsound mind" is still recognized as a basis for the judgment. Id. $\S 4425(\mathrm{c})$.

148. See generally AILEN 299-313.

149. Cal. ANn. Prob. Code $\S 20$ (West Supp. 1971). A similar requirement is found in the UNIFORM Probate CODE \& 2-501 (1969) ("Any person 18 or more years of age who is of sound mind may make a will").

150. Estate of Elliott, 114 Cal. App. 2d 747, 749, 250 P.2d 684, 685-86 (2d Dist. 1952).

151. Estate of Powers, 81 Cal. App. 2d 480, 483-84, 184 P.2d 319, 321 (1st Dist. 1947).

152. Estate of Nelson, 227 Cal. App. 2d 42, 52-56, 38 Cal. Rptr. 459, 465-67 (1st Dist. 1964).

153. Estate of Fossa, 210 Cal. App. 2d 464, 468-69, 26 Cal. Rptr. 687, 689 (1st Dist. 1962) (Testator executed will 30 minutes after laving been declared incompetent; will held invalid); Estate of Wolf, 174 Cal. App. 2d 144, 148-49, 344 P.2d 37, 40 (2d Dist. 1959).

154. See generally ALLEN 283-93.

155. Note, Testamentary Capacity in a Nutshell, 18 STAN. L. REv. 1119, 1134-35 (1966). 
narrow interpretations, holding sections 38 and 39 to be applicable only if the person whose capacity is in doubt lacked the ability to comprehend the specific transaction in question. ${ }^{156}$

Consistent with this restrictive view, the California courts have refused to merge a finding of incompetence in the commitment order, uniformly holding that an order of involuntary hospitalization for mental illness has the effect only of depriving the individual of his personal freedoin and providing him "proper care and remedial aid,"157 not of rendering him incapable of contracting. ${ }^{158}$ No cases have been found dealing with the mentally retarded who have been committed to a state hospital. ${ }^{159}$ However, utilizing reasoning much like that applied in the testamentary capacity area, Professor Weihofen has suggested that the similarity between an adjudication of incompetence and a diagnosis of mental retardation supports a stronger presumption of incompetence from institutionalization for mental retardation than from hospitalization for mental illness. ${ }^{160}$ Nonetheless, he urges that no hard and fast rule be established on the basis of this similarity.

Thus, we end where we began: with the proposition that the precise impact of commitment on the legal capacity of the mentally retarded patient is far from clear. Standing alone, the order may not, of itself, be more damaging than the diagnosis of inental deficiency which supports it. Taken together, and considered with other evidence of functional disability, there inay be an uncertainty of legal competence. That this uncertainty, anong other factors, affects the planning by parents for the future of their mentally retarded children will be seen in the parts that follow. Before leaving this section, however, it is appropriate to join with the Mental Competency Study in its recommendations that hospitalization and incompetence should be completely distinct is-

156. E.g., Jacks v. Estee, 139 Cal. 507, 73 P. 247 (1903) (involving a note and mortgage executed by the decedent who, at the time of execution was 85 years old and mentally infirm, but who had never been adjudged incompetent).

157. Fetterly v. Randall, 92 Cal. App. 411, 413, 415, 268 P. 434, 435 (2d Dist. 1928).

158. Hsu v. Mt. Zion Hospital, 259 Cal. App. 2d 562, 572, 66 Cal. Rptr. 659, 664 (1st Dist. 1968); In re Zanetti, 34 Cal. 2d 136, 142, 208 P.2d 657, 660 (1949). See generally Weihofen; ALLEN 260-82.

159. One California case affirmed in part and reversed iu part a judgment refusing to cancel two deeds because the lower court failed to determine the issue of plaintiff's mental capacity. In remanding the case for trial on the issue of plaintiff's competence, the court of appeals pointed out that testimony of a clinical psychologist that plaintiff was "a borderline mental defective whose mental abilities were limited to simple, everyday situations, and who was unable to deal with abstractions such as the concept of titie to property" could support, but would not necessarily in itself compel, a finding that plaintiff came within section 39 as a person of "unsound mind, but not entirely without understanding." Peterson v. Ellebrecht, 205 Cal. App. 2d 718, 722, 23 Cal. Rptr. 349, 351 (3d Dist. 1962).

160. Weihofen 223-24. 
sues for the mentally retarded as well as for the mentally ill and that care should be taken to ensure that the hospitalized retarded patient in fact is permitted to enjoy the legal rights he is capable of exercising. ${ }^{161}$

\section{II}

\section{Parental Impressions of Legal Aspects of Mental Retardation}

\section{A. Methodology}

The 120 families interviewed were chosen from six groups:

1) those whose mentally retarded child had been committed to Sonoma State Hospital from the Bay Area of northern California within the 3-year period immediately preceding the sample selection; 2) those who had applied to Sonoma State Hospital for their child's admission and whose child had been determined eligible and suitable for hospital care by the hospital staff but had not yet been committed; 3) those whose child was enrolled in a public school program for the tramable retarded in the county of residence of the families in group 2;

4) comparable families to those in group 1 , but whose child had been voluntarily admitted to Pacific State Hospital from the Los Angeles area of southern California;

5) comparable families to those in group 2 , whose child had been accepted for care in Pacific State Hospital; and

6) families whose child was enrolled in a public school program for the tramable retarded in the county of residence of the families in group 5 .

Thus the basic research design was a 3 (hospital, waiting list, public school) $\times 2$ (northern California, southern California) factorial one, with twenty families in each cell for a total of 120 families.

The families included in the four groups of new and pending admissions were randomly chosen after the lists had been limited in important ways. Selection began by eliminating from consideration all patients or prospective patients whose families did not live in the counties that represented the principal source of patients for the two state hospitals. Sonorna State Hospital serves 31 counties in northern California, but between 80-90 percent of its patients coine from the five. most populous counties centering around the Bay Area. The sample was limited to those five counties. Pacific State Hospital serves the three southern California counties of Los Angeles, San Bernardino, and Riverside, but nearly 90 percent of its patients reside in Los Angeles County and the sample was bmited accordingly.

161. ALLEN 228-34. 
The second limitation restricted the sample to patients who were ambulatory and not specially handicapped by blindness, deafness, or other major motor defects. The likelihood of hospitalization for nonambulatory mentally retarded children would appear to be greater than for those who are ambulatory, and their chances of participating in public school programs smaller. Consequently, parents whose children were nonambulatory might have less freedom of choice as to whether hospitalization is appropriate.

The third restriction dealt with I.Q. levels and with age. All patients who were younger than 6 years of age or older than 18 years were eliminated from the sample, as were all patients with I.Q. levels less than 30. These restrictions were imposed in order to permit comparison with the public school sample. The I.Q. score used in sample selection was that obtamed by the hospital or school in determining eligibility for its own program. No independent I.Q. testing was attempted.

The final restrictions dealt with family composition. An attempt, not always successful, was made to screen out children who had other retarded siblings. A successful limitation was that each family be intact in the sense that there be two parents (perhaps stepparents) in the home, both of whom would potentially be involved in planning for the care of the retarded child.

After these limitations had been observed, the occupational status of the father was determined. The four hospital and preadmission samples were then chosen so that each group of four families was as well matched as possible for sex of retarded child, age of the child, I.Q. level of the child, and father's occupational level. No attempt was made to select families who were likely to be cooperative. Despite this omission, there was an extremely low refusal rate.

Selection of families whose children were enrolled in public school classes could not be done by the research staff. Instead, the selection of the two community samples was left to school personnel who were given a description of the characteristics of the child and his family from the waiting list group and asked to find a child and family to match. This procedure, made necessary by the desire of school personnel to protect the confidentiality of their files, may have resulted in the choice of families likely to cooperate.

Once the samples were chosen, the hospitals and schools contacted the families, enclosing a letter prepared by the research staff explaining the research goals and providing a post card for the family's use in notifying the researchers of their willingness to participate. Upon receipt of the post card, an appointment was made for individual interviews of the mother and father, followed by a brief joint interview. Two 
interviewers were used: a psychiatric social worker and a clinical psychologist. In order to eliminate bias due to the personality of the interviewer or the order of the parental interviews, each interviewer saw half of the families in each of the six subgroups, and within that half, fathers were interviewed first in half the families and mothers were interviewed first in the other half.

The interview was designed for maximum flexibility in eliciting information froin parents about the child's developinental history, his effect upon the family, the family's contacts with community agencies in dealing with the child, and their legal planning for the child. Families in group 1 whose children had been committed to the state hospital by court proceedings were questioned about the procedure and their reactions to it. Interviews were conducted in the family home and were tape-recorded.

Two psychological tests were used to supplement the information obtained from the interview. These were the Cain-Levine Social Connpetency Scale and a Semantic Differential rating of family concepts. The Cain-Levine Social Competency Scale was designed to measure the developinental level of learned skills that permit the child to become more independent and to contribute socially. Social competence is reflected in the child's manipulative ability or motor skills, in his ability to direct himself rather than wait for others to direct his behavior, in his concern for others and his social skills, and in his ability to make himself understood. The 44 items in the test are divided into subscales reflecting four dimensions of independence: self-help, initiative, social skills, and communication. The social competency rating was obtained by interviewing each parent separately to determine the child's usual or typical performance. The items are quite explicit, and interpretation or inference by the interviewer is minimal. ${ }^{162}$ Because the test was developed specifically for the evaluation of trainable retarded children, it was deemed appropriate for the families in this study. The administration of the test is standard, providing coinparable information froin both parents and from all families. The Cain-Levine was thus seen

162. Item No. 1, "Dressing," is as follows:

1. Cannot put on any clothing.

2. Can put on most clothing, can zip, cannot button.

3. Can put on most clothing, can zip and button.

4. Completely dresses self except for shoe tying.

5. Completely dresses self including shoe tying.

"The descriptive statements within each item are ordered by difficulty level and are numbered from one through four or five, with level one representing the least independent level of social competence and level four or five representing the most independent level." L. CaIN, S. LeVINE \& F. Elzey, Manual for the CaIN-Levine Social COMPETENCY Scale 5 (1963). 
as a corrective for the interviews, which allowed considerable latitude to the parents.

The Semantic Differential is a set of paper and pencil ratings, completed by each parent separately and intended to provide information in the area of family relationships. The concepts rated were wife (or husband), man, woinan, self, ideal self, ideal wife (or husband), son, daughter, ideal child, and the mentally retarded child (by name). The scales on which these concepts are rated are: hard-soft, fast-slow, kindmean, light-heavy, good-bad, nice-awful. The concepts were presented in random order, the favorable and unfavorable ends of the scale were presented randomly first or second, and the scales themselves were presented in random order to prevent various position biases from influencing the results. The parents checked the scales themselves without interference by the interviewer. In a few cases literacy or language problems prevented administering the Seinantic Differential, so the results are not uniformly available.

\section{B. Findings: The Family Situation}

\section{The Hospital Group}

The 40 families in the hospital group ${ }^{163}$ had all placed their children in a state hospital for the mentally retarded. The 20 families from northern Califorma had all experienced the court-commitment procedure described in part I as part of the admission process. The 20 families from southern California had followed the voluntary admission procedure in use at Pacific State Hospital. In placing their children, all but two of the 40 families had followed advice given them by professionals in the community: doctors (27), teachers (6), public health nurses (2), social workers (2), and school counselors (1). ${ }^{164}$ The two families who had not been professionally advised to hospitalize their child had talked to other parents of retarded children.

Fifteen of these families had been given medical diagnoses by their child's first birthday; 18 other children had been diagnosed by age 3; the remaining seven were diagnosed before they reached school age. ${ }^{105}$

163. No statistically significant differences appear between families from northern and southern California in any of the three major groups-the hospital sample, the waiting list sample, and the community sample. Hence, findings are reported together for each of the three groups, collapsing the six subgroups into three. Where slight differences exist, they are commented on in the text.

164. Only the principal advisor is reported. Many families received advice from more than one source.

165. Medical diagnoses for these children were obtained, with their parents' permission, from the hospital records. Nine were classified as having encephalopathy (unknown cause); six had had defective fetal development (one resulting from ru- 
Although all 40 children had been placed in a state hospital, only 27 of them were hospital residents at the time of the interview. ${ }^{166}$ Only 33 of the 40 families saw institutionalization as the ultimate plan for their child. Five families hoped that a sheltered workshop or other protective environment might become available. Two other families planned to bring their child home again.

All of the parents had inquired prior to placement whether they could bring their children home to live if they so desired. Without distinction between those who had been exposed to the court-commitment procedure and those who had voluntarily admitted their children, all reported to the interviewers their understanding that they would be permitted to bring their children home permanently after hospitalization. Indeed, as reported above, ${ }^{167}$ three northern Califorma families whose children had been committed through court proceedings did remove their children from the hospital without objection from the hospital. One mother did report that the hospital's social worker had come once to call on her after the child had returned home, but no objection was raised.

The interviews disclose little support for the idea that the parents who had been exposed to the court-commitment procedure found it a disturbing experience. The efforts of the local agents to minimize the import, and thus the impact, of the court procedure, ${ }^{168}$ appear to have been highly successful. All 20 parents from northern California reported that they had been told by the local hospital agent that the court hearing preceding their child's hospitalization was a mere formality, required by the state to legalize the adinission or to make sure that the child was really suitable for admission. None of them consulted an attorney for advice regarding their court appearance; no one had advised them to do so, and none thought of doing so independently. One fainily talked to a friend who was a bailiff in another court about the proceedings; a second family discussed the matter with the father's brother, who was an attorney; and a third father was advised by a municipal

bella, another from prenatal injury); six had mongolism; two were born prematurely; one had PKU; three had suffered anoxemia at birth; one was hydroceplalopathic; seven had congenital cerebral defects; and the remaining five were classified simply as being mentally retarded from an unknown cause.

166. Eight children were living in the community with private families as part of the hospital's program of foster-home care for its patients. (Six of those children were from southern California and two from northern California) Two children had been admitted to Pacific's day-care program, attending the hospital during the day but living at lome at night and on the weekends. Three children from northern California had been removed from the hospital by their parents; two of these children were living at home and one was in a private facility.

167. See note 166 supra.

168. See text accompanying note 82 supra. 
judge who lived nearby. Most families were startled when asked whether they would liave preferred that a court not be involved in the admission process, but after brief reflection they were divided on the value of court involvement. Some parents felt they would have preferred a less formal admission procedure, while others leeld firmly to the idea that the legal commitment provided a necessary protection for the child. One father, who had previously been involved with the criminal courts, thouglit the court commitment liad created a criminal record against his son. Most parents could not remember whether the judge liad asked them any questions or whether they had inquired anything of liim. Some raised objection to the summary nature of the proceedings. For example, one father stated that, in lis view, the legal procedure was a farce: "As far as the judge deciding whether [our son] was retarded or not, it was ridiculous." To the majority, the legal procedure was simply one more necessary step along the path to liospitalization.

The southern California families had not participated in a court hearing prior to their child's admission to the hospital. Since none of the children lrad yet become 21, commitment was not required by the lospital's policy. Few of the southern California families, however, were concerned about the prospect of future commitment. None stated that they would withdraw their children from the hospital in order to avoid commitment.

Interestingly enougl, no difference is apparent between the northern and southern lospital families regarding their perceptions of low authority over the child is divided between themselves and the hospital. Both groups feel that they can remove their children from the lospital at any time; neither group has any clear understanding of what civil rights (for example, marriage, voting, applying for a driver's hicense) the child enjoys after hospitalization, although all but one of the 40 families feel the matter is not important since the child is not capable of such activities in any event; ${ }^{169}$ and both groups report liaving been asked to sign medical releases permitting the liospital to perform surgery on the child. Thus, if the court proceeding has any impact at all apart from confirming the child's admission to the hospital, the parents are not aware of it.

Only slightly over laalf (21) of these families liad joined a parents' group, such as Aid to Retarded Children, a local parent-teachers' association, or a parents' ward group at the lospital. Five families were

169. The similarity between the-parental view and the judicial view of whether these children were capable of enjoying their civil rights is striking. See text following note 106 supra. 
very active in such groups; others planned to become active or to join the hospital group.

\section{The Waiting List Group}

The 40 families in the waiting list group had all made application to place their children in a state hospital for the mentally retarded. Like the hospital group, nearly all of thein (37 families) had been advised to place their children by professionals in the community: doctors (26); teachers (3); public health nurses (4); and social workers (4). Two families had been advised to place their children by friends who were parents of retarded children. One family did not intend to request full-time placement and had applied only to take advantage of the day-care program at Pacific.

Twenty-two of these families, compared with 15 in the hospital group, had been given medical diagnoses by their clild's first birthday. Eleven families had received diagnoses by the child's third birthday, and the remaining seven children were diagnosed before school age. ${ }^{170}$

Two of these 40 children were hospital residents at the time of the interview. One child had been admitted the week before the interview, and one other child had been temporarily placed in Agnews, a northern California hospital for the mentally ill, awaiting permanent placement in Sonoma. Ten clildren were in private facilities. The remaining 28 children were hiving at home. Many of these families have made "insurance" applications: they do not intend to place their child when his turn comes up. Indeed, some families had already refused placement, and several had been transferred to deferred waiting lists. Only 13 families were actively waiting for an early placement for their child at the time of the interview.

Twenty-seven of these families, as compared to 33 families in the hospital group, see the state hospital as the ultimate residence for their child. Six families hope to bring their child home after he receives education or habit training at the hospital or after the other children have left home. The remaining seven families are doubtful whether a state hospital is the ultimate home for their child. ${ }^{171}$ Eighteen of these families are members of parents' groups, and three are very active members.

170. Again, hospital records were examined with parental permission and the following medical diagnoses were obtained: mongolism (15); encephalopathy (13); cerebral defect (4); gargoylism (1); anoxemia at birth (1); Rubenstein's Syndrome (1); spastic (1); defective fetal development (2); and mental retardation, unknown cause, (2).

171. In one case this reflects a disagreement between the mother and father; in the other cases it is a desire (supported in a few cases by medical advice) to wait and see how the child develops before deciding. 


\section{The Community Group}

None of the children in the community group was living in a state hospital at the time of the interview. All except one, who was in a private residential school, lived at hoine and attended public school classes for the mentally retarded. Only 10 of these families saw the state liospital as the ultimate place of residence for their child. ${ }^{172}$

Twenty-four of the 40 families reported that hospitalization was advised for their child by community professionals: doctors (21); social workers (2); and an insurance agent (1). Two other families were so advised by friends. Each of eight families who had applied for hospital admission was among the group of 24 who were professionally advised to do so. Nineteen of these families had received a medical diagnosis of their child's condition before the child's first birthday; 11 others had the diagnosis by the time the child was 3 ; and the remaining 10 had a diagnosis before the child had reached school age. ${ }^{173}$

Families in the community group appear to be unore actively involved in obtaining services for the mentally retarded than families in the other two groups. Twenty-seven of these families were mesnbers of parents' groups, and seven of them were very active. A few families had been instrumental in forming parents' groups and in starting special programs for their children. As noted earlier, ${ }^{174}$ these families were selected by school persomiel rather than by random methods; this selection may account for the higher parents' group activity among this group.

These families also appear to function more effectively as a unit than families in the other groups, perhaps for the same sampling reason noted above. The figures indicate, however, that 23 families in this group report taking their retarded child on vacation trips, such as camping, compared with 11 families in the waiting list group and seven in the hospital group. And only one family in the community group reported the existence of marital strain related to the retarded child, compared with 10 families in the waiting list group and seven in the hospital group.

\section{Discussion}

One cannot read the transcripts of the family interviews without being moved by the parents' descriptions of themselves and their

172. Eight of these families had made application to the local state hospital for their child's admission; seven of them saw these as insurance applications.

173. Since these children, in the main, had no hospital records, medical diagnoses are not available for them. The parents reported, however, that 19 of the 40 children had been diagnosed as having inongolism, a slightly higber number than in the waiting list group, which had 15 . It is not possible to classify the remaining 21 cbildren in a manner comparable to the diagnoses available for the other two groups.

174. See part IIA supra. 
children. Listening to the tape-recordings, of course, deeply reinforces this feeling. In describing their hopes during the pregnancy, many mothers said they had not wished for a child of a particular sex, only a child who would be healthy. For 23 of the 120 families, the initial shock of learning that their baby was not healthy, in the sense of not being normal, came at birth. Seventeen of these infants were mongoloids. The way in which the diagnosis was communicated to the parents often seemed unnecessarily harsh: one mother recounted being moved from a ward to a private room so that, as she perceived it, others would be spared the sight of her child. A father, inquiring about the baby shortly after its birth, received the brusque response from a nurse, "Well, you know he's a mongoloid, don't you?" Parents of the other 23 mongoloid children in the study did not learn of their child's condition until later: 16 by the time the child was 6 months old; three when the child was 1 ; three when the child was 2 ; and one, a family who moved to a new community and consequently changed pediatricians, not until the child was 3 . Several of these parents were convinced that the doctor who had delivered their child knew of the condition at birth and simply liad not wished, out of what they saw as misplaced kindness, to tell the parents. Some doctors who did not inform the parents of their child's mongolism at birth did refer them to specialists who made the diagnosis.

For the 80 families whose children were not mongoloids, diagnosis was generally slower and less specific. Only six of these families learned of their child's condition at birth: three had birth injuries or deformities, and one each was diagnosed as having possible mongohism, Rubenstein's syndrome, and congenital encephalopathy. Age of the child at diagnosis is not available for one family. Of the remaining 73 families, eight received a diagnosis by the time the child was 6 months old; six by the first birthday; 15 by the second birthday; 21 by the third birthday; and the remaining 23 before the child reached school age. Many of these families experienced the well-known round of visits to doctor after doctor, clinic after clinic, in their search for medical advice and diagnosis.

All but three of the 120 families brought their children home after birth. Two children spent approximately 6 months in nursing homes before coming home to their parents. Only one child, a mongoloid, was taken directly from the lospital to a foster lrome and then to the state hospital, never living with her parents. Those parents who brought their children home recounted problems of daily care and management: 84 had problems with toilet training, 33 found feeding difficult, and others had problems with the child's waking during the night and making noise. Twenty-three parents, lowever, experienced no special 
problems with habit training and felt that their retarded child was no more difficult to raise than their normal children.

Fifty-five children had some experience in kindergarten, nursery school, or day-care training centers before they were 6 years old. Many of these schools had been established by parents' groups, some by the parents in our study group. Children who were not toilet trained, or who were hyperactive, were less acceptable to the schools; many of these children did not enter school until age 6 or older. By the time of the interview, however, 91 of the 120 children were attending school regularly. Twenty-three of these children went to school at one of the two state hospitals; the other 68 either attended public school classes for the trainable retarded or private schools.

Parents had many comments on their experiences with the public schools. Some dismissed the entire prograin as a mere babysitting arrangement, while others were pleased with the progress their children had achieved in social skills and habit training. Many parents spoke highly of the special school bus that picked up and dehvered their children each school day. In reflecting on what services they felt should be provided for the retarded, 61 families mentioned the need for more school facilities. Many of these families were distressed that the public school program ends when children become 18. They would bike the school program to continue at least until the child reaches 21 . Fortytwo families would like to have more sheltered workshops, perhaps as part of the school system. Thirty-one families mentioned the need for day-care centers and preschool placement facilities.

All but five of the 83 families who had admitted their children to state hospitals or had applied for admission did so upon professional advice. In discussing the reasons that prompted them to seek hospitalization, families mentioned fears that the retarded child's continued presence in the home might inhibit the social life of their other children, the burden of day-to-day care of the retarded child (which was seen as increasing with the child's age and physical strength), and fears (expressed by mothers only) that their mentally retarded daughters would be sexually exploited.

No conclusions can be drawn froin the data as to what factors distinguish the families who had decided to place their child froin those who kept the child at home. Gross factors such as degree of retardation, lack of one parent in the home, extreme disparity in incoine and community facilities that have been reported by other studies ${ }^{175}$ were absent from our sample because of the limitations established over se-

175. E.g., SAENGER, Factors INFLUENCING THE INSTitutionalization of MENTALly Retarded Individuals in New York City: A Report to the New York State INTERDEPARTMENTAL HEALTH RESOURCES BOARD (Jan. 1960). 
lection of the study group. ${ }^{176}$ The pencil and paper tests administered to all families did not provide any consistent variation in their perception of the child's abilities that could account for their different responses to institutionalization. The frequency distributions of subtest scores and total scores on the Cain-Levine Social Competency Scale disclosed no differences among the original six groups in either mean scores or in variability within the groups. ${ }^{177}$ Because of the obvious

Table 12. Cain-Levine Scores

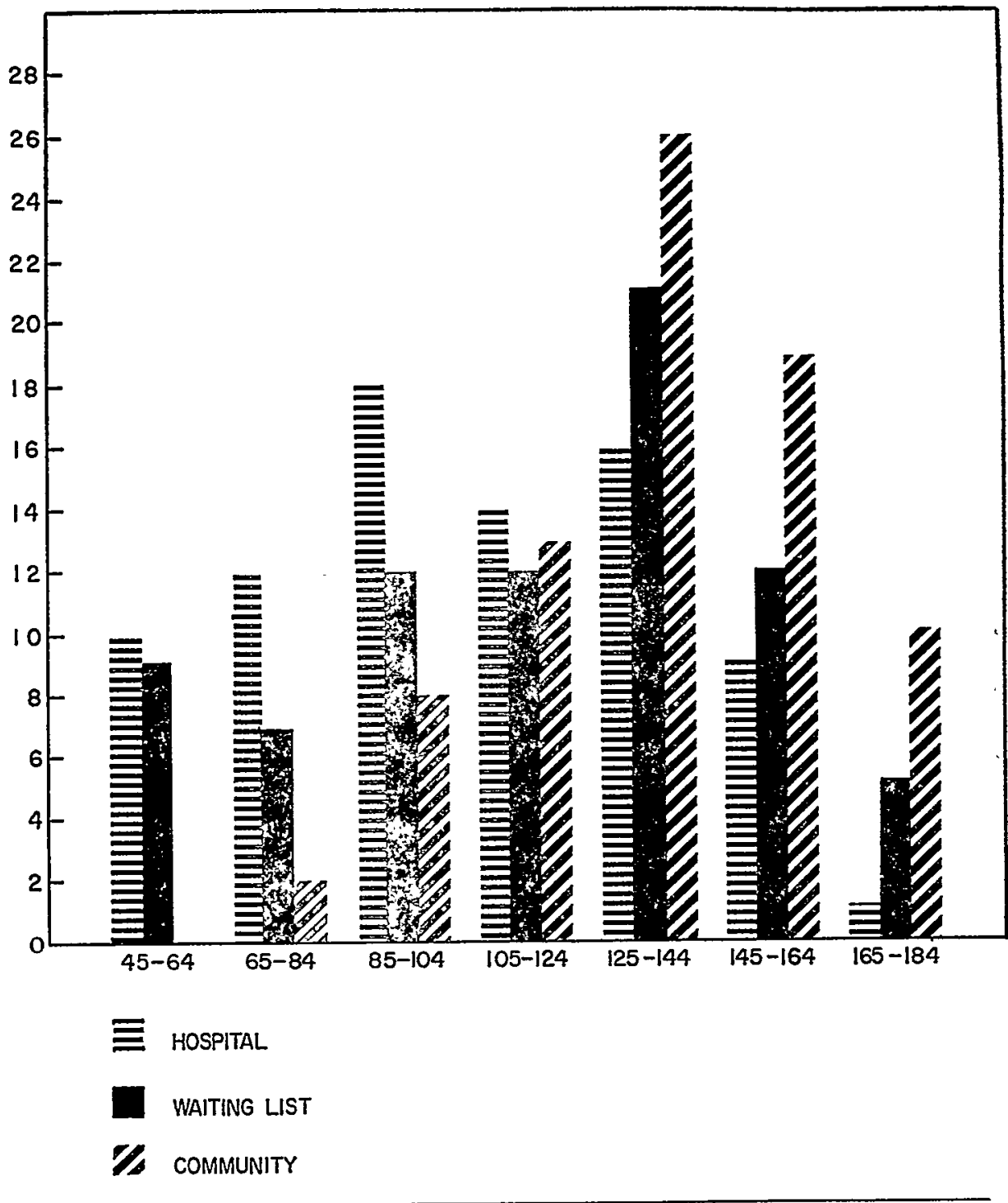

176. See part IIA supra.

177. Nor did any differences exist among the six groups im the Semantic Differential Test. 
similarity among groups, no further analyses of the pencil and paper tests were undertaken.

Results of the Cain-Levine scores are shown graphically in table 12. Numbers at the bottom of table 12 represent individual scores for each child on the Cain-Levine Scale, arranged in groups of 20 . The highest possible score is 182 . Numbers at the left side of table 12 represent the number of individual parents who gave a particular score to their child. Because Cain-Levine scores are not available for two families, the number of parents adds to 236, rather than 240 .

Although there are no statistically significant differences among the original six groups, table 12 suggests a slight tendency for parents in the combined community samples to report their retarded children as being more competent than do parents in the waiting list and hospital sainples. Larger sainples would be required to test the validity of this tendency.

The incidence of parental disparity in rating their children on the Cain-Levine Scale is shown graphically in table 13. Numbers at the bottom of table 13 represent the disagreement, in points, between parents in rating a particular child. Numbers at the left side of table 13 represent the number of families whose disparity falls in each category. The total number of families is 118, rather than 120: 40 in the hospital group and 39 each in the waiting list and community groups.

Table 13. Parental Disparity (Cain-Levine).

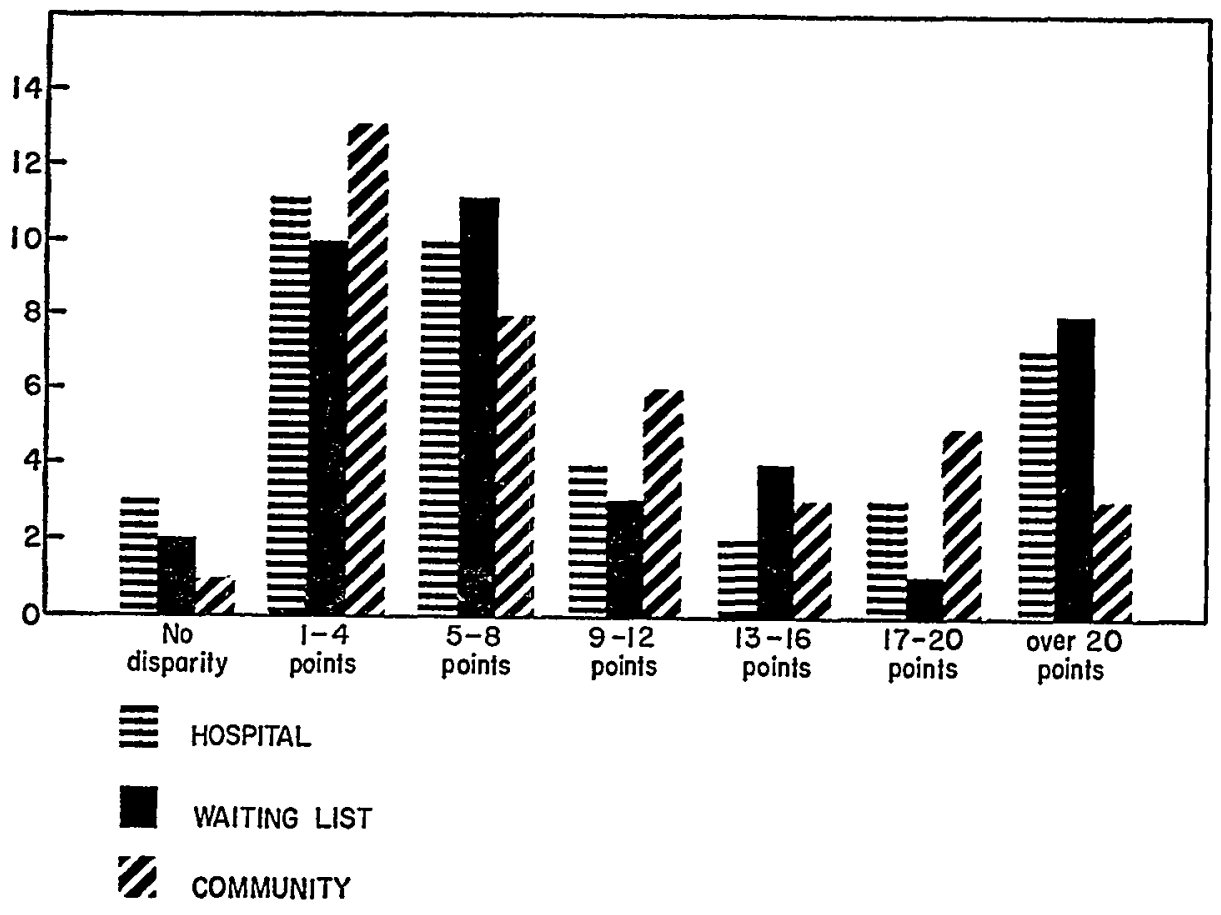


Table 13 indicates that parental agreement in judging a child's total competence was similar across the three groups. Scores obtained from almost 60 percent of parents in each of the three groups differ by eight points or less on a 182-point scale. Approximately equal proportions of families in the three groups yield discrepancies greater than eight points. A slight but, in view of the overall agreement, probably insignificant difference in scoring exists between mothers and fathers. Of the 112 families where parental disagreement exists, ${ }^{178}$ mothers rate the child higher in 67 families and fathers rate him higher in 45 families. The spread between groups is shown in table 14. The slight difference shown in table 14 between motlers and fathers in the two groups where the child lives at home in most cases (waiting list and community ${ }^{179}$ ) is probably explained by the inother's closer daily association with the child. Mothers worked outside the home in only 16 of these 80 families; in one of these cases, the child did not live at home.

Table 14. Mother-Father Disparity (Cain-Levine).

\begin{tabular}{lcc}
\hline & Mother Higher & Father Higher \\
\hline Hospital & 18 & 19 \\
Waiting List & 22 & 15 \\
Community & 27 & 11 \\
\hline
\end{tabular}

The parents were all concerned about the futures of their children. Seventy families could see no alternative to state hospitalization as the ultimate plan for their children; but 29 families, 21 of whom belong to the community sample, rejected the state hospital as a potential resource, while 21 others had not been able to inake definite plans. The families were willing to explore available alternatives. California's new regionalcenter plan for the mentally retarded ${ }^{180}$ was just beginning operation during the field-research period. Two regional centers had been established: the Golden Gate Regional Center in San Francisco, serving the Bay Area counties, and the Children's Hospital Regional Center in Los Angeles. Nine families in the northern hospital and waiting list groups were in contact with the Golden Gate Regional Center and four in the southern waiting hist group were working with the Los Angeles Regional

178. In six families, no disagreement existed. In two families, no scores are available.

179. See parts $\operatorname{\Pi B}(2) \&(3)$ supra.

180. The regional centers were proposed in 1965. Cal. Study Comm'N on Mentai Retardation, The Undeveloped Resource: A Plan for the Mentally Retarded in California 46-50 (Jan. 1965) Thereinafter cited as The Undeveloped Resource]; Assembly Commitree supra note 8, at 30-40. The San Francisco and Los Angeles centers were established in 1966. 
Center. Those families were uniformly enthusiastic about the centers and hoped that they would prove instrumental in developing alternatives to state hospitalization for their children. ${ }^{181}$ Ten regional centers are presently in operation in California, and three more have been authorized to begin services between January 1 and June 30,1972, to provide a statewide network of 13 regional centers. These centers have primary responsibility for the public guardianship program established in $1968,{ }^{182}$ which is discussed in part IIII.

\section{Findings: Legal Aspects of Parental Planning}

One of the most obvious findings of the study is that parents do not perceive mental retardation as a legal problem. As we have seen, none of the parents in the northern hospital sample had consulted an attorney concerning their appearance in court as part of the hospital admission process. ${ }^{183}$ Time and agam the interviewers, in explaining the purposes of the study to the parents, were asked why there should be a legally oriented study of mentally retarded persons and their families. Interview questions asking what the families would like the law to provide with respect to mentally retarded children brought responses indicating that there was nothing the law could do about mental retardation. However, when the question was rephrased to direct attention to the role of legislation in establishing state services for the mentally retarded, answers were more readily available. ${ }^{184}$ It appears that the initial reaction to "the law" of most families in our study was to think of its function as an element of social control rather than its more ameliorative task of providing for social welfare. This attitude may be due in part to the failure of lawyers to become actively involved in solving probleins related to mental retardation: the field has not been defined as one im which lawyers should be interested, just as the entire field of welfare rights and the law of the poor was not defined as presenting legal issues until the 1960 's. ${ }^{185}$

When the interviewer began asking about plans for the child's future following the death of the parents, however, the parents immedi-

181. During the first year of operation, 230 persons on the state hospital waiting list were served by the Los Angeles Regional Center, and all but 39 of them were cared for in community facilities. See Cal. Assembly Office of Research \& Stafp of Cal. Assembly Ways and Means Committee, A Proposal to Reoronnize CalmorNiA's Fragmented System of Services for the Mentally Retarded i (1969) [hereinafter cited as A Proposal].

182. Cal. AnN. Health \& Safety Code $\S \S 416-416.23$ (West 1970).

183. See text following note 168 supra.

184. See text preceding note 175 supra for some of the services the families felt the law should provide.

185. See Carlin \& Howard, Legal Representation and Class Justice, 12 U.C.L.A.L. REv. 387-88 (1965). 
ately recognized the relevance of the law of testamentary succession. Fifty-three parents in our sample of 240 , or 22 percent, had already made wills at the time of the interview. Their distribution among the three major groups is shown in table 15. Testacy of wives is highly correlated with testacy of husbands. As table 16 shows, all but one testate wife had a testate husband; six testate husbands had nontestate wives. The fifty-three testate parents are thus distributed among only 30 of the 120 families, giving an overall 25 percent family testacy.

Table 15. Testate Parents.

\begin{tabular}{rcc}
\hline & Father Testate & Mother Testate \\
\hline Hospital & 14 & 11 \\
Waiting-List & 8 & 6 \\
Community & 7 & 7 \\
\hline Totals: & 29 & 24 \\
\hline
\end{tabular}

Table 16. Family Testacy.

\begin{tabular}{cccc}
\hline & H-W Testate & H only Testate & W only Testate \\
\hline Hospital & 11 & 3 & 0 \\
Waiting List & 6 & 2 & 0 \\
Community & 6 & 1 & 1 \\
\hline Totals: & 23 & 6 & 1
\end{tabular}

The significance of these figures is put into context by comparing our sample with the data presented by a recent study of testacy versus intestacy in 659 decedent estates in Cuyahoga County, Ohio. ${ }^{186}$ The Cuyahoga County study associates testacy positively with age, economic class, and social status. ${ }^{187}$ The data from our study shows a corresponding association.

Table 17. Age Group of Parents and Percent Testate.

\begin{tabular}{cccc}
\hline Age Group & Number & Number Testate & Percent Testate \\
\hline $21-29$ & 8 & 1 & 12.5 \\
$30-39$ & 86 & 8 & 9.3 \\
$40-49$ & 101 & 30 & 29.7 \\
$50-59$ & 36 & 11 & 30.5 \\
$60-69$ & 7 & 3 & 42.8 \\
\hline Total & $238^{*}$ & 53 & 22.2 \\
\hline
\end{tabular}

*age not available for two parents, both nontestate

186. M. Sussman, J. Cates \& D. Smith, The Family and Inheritance (1970). [Hereinafter cited as SUSSMAN].

187. Id. at 64 . 
Table 17, corresponding to table 4-2 of the Cuyahoga County study, ${ }^{188}$ shows the increase in our sample in rate of testacy with age. Social status was indicated in the Cuyahoga County study by occupation and education. ${ }^{189}$ In that study and in table 18, which corresponds to table 4-15 of the Cuyahoga County Study, ${ }^{100}$ housewives were omitted in the occupation index. Since so many of our testate mothers were housewives, table 18 includes only the 29 testate fathers. We did not have access to the occupational classification used for the Cuyahoga County study, and our sorting may not be identical to theirs. The distributions nevertheless confirm, even in our small numbers, that testacy increases with social class. Table 19, corresponding to table 4-17

Table 18. Occupation of Fathers and Percent Testate.

\begin{tabular}{lccc}
\hline \multicolumn{1}{c}{ Occupation } & Number & $\begin{array}{c}\text { Number } \\
\text { Testate }\end{array}$ & $\begin{array}{c}\text { Percent } \\
\text { Testate }\end{array}$ \\
\hline Unskilled manual & 6 & 0 & 0 \\
Semiskilled manual & 12 & 0 & 0 \\
Skilled manual & 29 & 3 & 10.3 \\
Clerical, sales, and technicians & 8 & 1 & 12.5 \\
Administrators, small busmess & 32 & 10 & 31.2 \\
$\quad$ and minor professionals & 21 & 8 & 38.2 \\
Managers and lesser professionals & 11 & 7 & 63.6 \\
Major professionals and top executives & $119 *$ & 29 & 24.3 \\
\hline \multicolumn{1}{c}{ Total } &
\end{tabular}

Table 19. Education of Parents and Percent Testate.

\begin{tabular}{|c|c|c|c|}
\hline Education & Number & $\begin{array}{l}\text { Number } \\
\text { Testate }\end{array}$ & $\begin{array}{l}\text { Percent } \\
\text { Testate }\end{array}$ \\
\hline Less than 8th grade & 10 & 1 & 10.0 \\
\hline 8 years grade school & 16 & 4 & 25.0 \\
\hline Some high sehool & 41 & 4 & 9.7 \\
\hline High school graduate & 106 & 19 & 17.9 \\
\hline Some college & 31 & 11 & 35.4 \\
\hline College graduate & 28 & 10 & 35.7 \\
\hline Advanced degree & 7 & 4 & 51.1 \\
\hline Total & $239 *$ & 53 & 22.1 \\
\hline
\end{tabular}

188. Id. at 65 . Because of the small totals yielded by our sample, numbers of testate persons have been included as well as percentages in each table.

189. Id. at 76.

190. Id. at 77 . 
in the Cuyahoga County study, ${ }^{101}$ includes both fathers and inothers and shows the relation between education and testacy.

Parents in our study were not asked for estimates of their total financial worth. Monthly incolne figures are, however, available for 119 of the 120 families. The Cuyahoga County study compares monthly incoine with testacy for a group of 1,121 survivors in table 4-13. ${ }^{192}$ Similarly, table 20 , in which the inonthly incoine of 20 wives is combined with that of their husbands, compares testacy with income. ${ }^{193}$

Table 20. Family Income and Percent Testate.

\begin{tabular}{cccc}
\hline $\begin{array}{c}\text { Monthly } \\
\text { Family Income }\end{array}$ & Number & $\begin{array}{c}\text { Number } \\
\text { Testate }\end{array}$ & $\begin{array}{c}\text { Percent } \\
\text { Testate }\end{array}$ \\
\hline$\$ 200$ or less & 1 & 0 & 0 \\
$\$ 201-400$ & 4 & 1 & 25.0 \\
$\$ 401-600$ & 22 & 1 & 4.5 \\
$\$ 601-800$ & 24 & 6 & 25.0 \\
$\$ 801-1,000$ & 31 & 5 & 16.1 \\
$\$ 1,001-1,500$ & 22 & 10 & 45.4 \\
$\$ 1,501$ and over & 15 & 7 & 46.6 \\
\hline Total & $119^{*}$ & 30 & 25.2 \\
\hline
\end{tabular}

"monthly income not available for one (nontestate) family

These comparisons of our data with the findings of the Cuyahoga County study appear to indicate that the presence of a mentally retarded child in the family does not alter the normal factors that motivate individuals to make wills: advancing age, relatively high social status, and a favorable econonic position. Our sample is not large enough to enable us to predict whether parents of retarded children are more likely to make wills when those factors are present than other parents. The most that can be said is that our testate parents appear to share the same general characteristics that inark other testate individuals.

Not all of our 30 testate families, however, made financial provision for their retarded children in their wills. Twenty-two families had done so, but eight had not. In three families, the will had been executed prior to the child's birth, and two of those families had plans to change the will to include the retarded child. In five families, however, the exclusion was deliberate: in one case the attorney who prepared the will advised the family that the child would be provided for

\footnotetext{
191. Id. at 78. The classification "advanced degree" has been added to the SusSman table.

192. Id. at 75 .

193. The reference is thus to total family income rather than individual income. and the testacy total becomes the 30 families of table 16 in which either husband or wife or both were testate.
} 
by social security and that further funds would not be necessary. In two other cases, social workers in different community agencies gave essentially the same advice. In a fourth case, the mother's sister was the sole beneficiary and the mother expected her to look after the child's needs. The final family disinherited their child because they believed that any money or property left to an institutionalized retarded child will belong to the state..$^{194}$

Of the 22 families who have included their retarded child in their wills, 14 have left property to the child outright and eight have established trust funds for their children. All but two of the families who have wills consulted an attorney with respect to their wills.

In addition to the 30 families already testate, 39 other families planned to make wills and to provide for their retarded children in those wills. Twenty-six families planned to make wills that will disinherit their retarded children. Six of these 26 families believe that any property left to the child would belong to the state; ${ }^{195}$ nine others think it unnecessary for them to leave money to the child since the state will provide for his care through the state hospitals; and the remaining 11 families plan to leave all their property to their other children, who will see that the retarded child's financial needs are met.

Nine families plan to make no wills: one father intends to "avoid probate" by the use of joint bank accounts, while eight families feel their property is insufficient for a will. The remaining 16 families in the 120 -family sample have not decided what to do about succession. Nine of these families are providing for their children, including the retarded child, through life insurance.

Virtually all of the parents indicated concern about what would happen to their children after the parents' death. Although only a few parents thought that they would survive the retarded child, only 14 families had taken the step of appointing a guardian to look after their child upon their deaths. Thirteen of those families had appointed a guardian by will; one family, having been advised by an attorney that their property was insufficient to justify a will, had nominated a guardian in a nontestamentary document. As the second line of table 21 shows, all of the 14 guardians who had been nominated were family members: seven were siblings of the parents, four were other children, two were the child's grandparents, and one was the inother's niece, reported in the category "other relatives."

194. This belief is well-founded. CAL. ANN. WeLF. \& INST'NS CODE $\$ 7513$ (West Supp. 1971) provides that a mentally retarded person and his estate are liable for the cost of his care and treatment while a patient in, or on leave of absence at state expense from, a state hospital. The statute was upheld as constitutional in Estate of Preston, 243 Ca1. App. 2d 803, 52 Cal. Rptr. 790 (4th Dist., 1966).

195. See note 194 supra. 
Guardianship was a difficult subject for most of the parents. The legal concept of guardianship was unfamiliar to many of them; most understood it generally as referring to "someone to look after my child after my death." Many of the parents were adamant in desiring that their other children not be obligated to take over the care of the retarded child after their death. Others, however, felt that their other children expected and even desired to take this responsibility. Yet only 29 families planned to name their other children as guardians of the retarded child, and some of those expected that the guardian would not take the ward into his home. Indeed, since 70 parents expect that their retarded children would ultimately be institutionalized, ${ }^{196}$ it is apparent that, should they appoint a guardian, most of them would not expect the retarded child to live with the person named. The top line of table 21 shows the responses of the 106 families who had not appointed a guardian to the question, "Whom would you consider naming as guardian?"107 Since solne families named more than one person, the responses add to a total of 112 . The total number of guardians shown in table 21 is 126.

Table 21. Guardianship Choices.

\begin{tabular}{|l|c|c|c|c|c|c|c|c|c|}
\hline & $\begin{array}{c}\mathrm{M} / \mathrm{F} \\
\text { Sib } \\
\text { lings }\end{array}$ & $\begin{array}{c}\mathrm{M} / \mathrm{F} \\
\text { Parents }\end{array}$ & $\begin{array}{c}\text { Ouher } \\
\text { children }\end{array}$ & $\begin{array}{c}\text { Other } \\
\text { relatives }\end{array}$ & Friends & $\begin{array}{c}\text { State } \\
\text { Hospital }\end{array}$ & Bank & Attorney & $\begin{array}{c}\text { Regional } \\
\text { Center. }\end{array}$ \\
\hline Plans & 40 & 11 & 29 & 5 & 5 & 15 & 5 & 1 & 1 \\
Nominations & 7 & 2 & 4 & 1 & 0 & 0 & 0 & 0 & 0 \\
\hline Total & 47 & 13 & 33 & 6 & 5 & 15 & 5 & 1 & 1 \\
\hline
\end{tabular}

Table 21 shows that close family members are the inajor choice for guardians: 93 of the 126 choices, or 73.8 percent, are members of the nuclear family of one parent or of the retarded child. The 15 families who listed the state hospital as their child's guardian were not speaking of a legal appointment. Rather, they felt that since the child either had been or would be placed in a state lospital, the appointment of a private guardian would be unnecessary. Four families inade reciprocal plans to nominate friends who also liad retarded children. The fifth family that planned to nominate friends chose the child's godparents. The parents who mentioned an attorney referred to the attorney who drafted their will and who would also act as executor. The family that planned to nominate the regional center had in mind the public guardianship program to be discussed in part III of this Article.

It is evident that what legal planning was done by these parents for their retarded children was done largely without the help of attorneys. Only 28 of the families had consulted attorneys. Some others liad dis-

196. See text following Table 14 supra.

197. The second line shows the persons chosen as guardian by the 14 families who had already made their nouninations. 
cussed future financial plans for their children with social workers or insurance agents. In our society, however, legal planning, as distinguished from legal advice, is not conducted only on an individual basis. During the research period, members of the research staff actively participated in legal planning for the mentally retarded on a statewide basis. The major result of this work was the new California Pubhic Guardianship Plan for the mentally retarded.

\section{III}

\section{Public Guardianship for the Mentally Retarded}

\section{A. Background: Perceiving the Need for Public Guardianship}

The Task Force on Law of the President's Panel on Mental Retardation, in its 1963 report, urged the development of a variety of guardianship plans for the retarded: limited guardianship of the person for the mentally retarded adult, with the scope of the guardian's authority carefully defined in the court's order; plenary guardianship for those persons incapable of basic self-management and routine day-to-day decisionmaking; conservatorship of the property for those adults capable of conducting their own daily affairs but whose disabilities prevent prudent management of substantial business or financial interests; and public guardianship to make these alternatives available to those for whom private guardianship is unavailable or not desired. ${ }^{108}$ This interest in public guardianship was encouraged and expanded by the California Study Commission on Mental Retardation. The commission's 1965 report stated that "public guardianship service should be available for every retarded person who needs it"; stressed that any such service should provide, in addition to legal and fiscal protection of property, a "continuing concern for the retarded person as an individual"; and recommended that its proposed Mental Retardation Program and Standards Advisory Board study the problem and make recommendations by the following year. ${ }^{100}$ The 1965 report of the Subcommittee on Mental Health Services of the California Assembly Ways and Means Committee made the study commission's proposal more concrete. It recommended that families accepted for service through the proposed new systen of regional centers be "permitted to transfer personal guardianship of their children to the Director of the California Department of Public Health after their child has been screened by a regional center."200 This proposal was accepted by the legislature: the 1965 leg-

198. TASK FORCE ON LAW, supra note 3, at 24-27.

199. The Undeveloped Resource 77. The Mental Retardation Program and Standards Advisory Board was created by ch. 1244, § 1, Cal. Stat. [1965] 3109. It is presently authorized by CAL. ANN. Health \& SaFETY Code $\$ 38200$ (West Supp. 1971).

200. AsSEMRly COMMITTEe 42. 
islation creating the regional diagnostic, counseling, and service centers ${ }^{201}$ contained the following guardianship provision:

The parents or guardian of a mentally retarded person may designate the Director of Public Health as guardian of the mentally retarded person on the death of the parents or guardian, if the state has assumed responsibility for providing care to the retarded person, through the regional center. Such guardianship shall be for the purpose of carrying out the recommendations of the regional center and to provide the retarded person with the assurance of continuity of care. 202

It seems apparent that this provision was intended merely as an interim ineasure until a comprehensive guardianship plan could be proposed and submitted to the legislature. The section, by its terms, applied only to persons who had been accepted by the regional centers. Since no regional centers were expected to be in operation before January of 1966, a brief interim period permitted establishment of a Committee on Guardianship under the auspices of the Califorma Mental Retardation Program and Standards Advisory Board, a citizen's advisory board attached to the State Health and Welfare Agency. ${ }^{203}$ The committee began its work on February 24, 1966; its ultimate product was the legislation enacted in 1968 that established California's plan of pubhic guardianship for the retarded. The process of drafting this legislation and presenting it for adoption is detailed in section B; the realiza-

201. Ch. 1242, § 1, [1965] Cal. Stat. 3106. The new legislation was numbered article 7.5, comprising $\S \S 115-416$, of the Health and Safety Code. This legislation was repealed by ch. 1594, §§ 2-8, [1969] Cal. Stat. 3234, and reenacted as CaL. ANN. Health \& Safety Code $\S \S 38100-01$ (West Supp. 1971). The regional centers are described in the text accompanying notes 231-43 infra.

202. Ch. $1242, \& 1$, [1965] Cal. Stat. 3106-07. The provision was formerly $\S 416$ of the Health and Safety Code. It was repealed by ch. 1099, $\S 1$, [1968], Cal. Stat. 345.

203. The original members of the committee were: Mrs. Vivian Walter, Chairman; Mr. Martin Dinkelspiel, attorney; Miss Bertha Kaminker, Juvenile and Psychiatric Departanent, Superior Court of Los Angeles County; Professor Herma Hill Kay, Executive Director, Family Law Project; Hon. J.K. McDonald, Supervisor of Ventura County; Mr. Edgar Pye, Golden Gate Regional Center. In addition to the members, five persons were named as Resource Persons: Mrs. Barbara Calais, Chief of the Bureau of Legal Services of the Department of Mental Hygiene; Dr. Charles Gardipee, Chief of the Bureau of Mental Retardation Services in the Department of Public Health (who was charged with establishing guidelines for the execution of the 1965 legislation quoted in text accompanying note 202 supra); Mr. Leopold Lippman, Coordinator of Mental Retardation Programs in the Health and Welfare Agency; Mrs. Elizabeth MacLatchie, Chief of the Adult Services Division of the Departinent of Social Welfare; and Mr. Jan Stevens, Deputy Attorney General. Miss Priscilla Myrick, Research Attorney for the project, was later added as a meinber of the committee. Mr. Frank O. Houston, Guardianship Administrator of the Department of Mental Hygiene, was added as a Resource Person, and was inost active as a nember of the drafting subcommittee. 
tion of public guardianship through the regional centers is briefly described in section $\mathrm{C}$.

\section{B. The Guardianship Committee and its Work: A Case Study in Legislative Process}

The guardianship law was not exclusively the work of professionals. The initial meeting of the guardianship committee was attended by representatives of the two major parents' groups in the state: Aid to Retarded Children (ARC) and California Council on Retarded Children (CCRC). The opinions of individual parents were solicited at various points throughout the drafting process, and the parents' groups were active in lobbying the bill through the legislature. Indeed, it was widely believed that the original 1965 legislation had been proposed and enacted as a direct result of pressure exerted upon the Assembly Committee by parents' groups. Moreover, CCRC was independently at work on plans for a private guardianship trust arrangement that would allow parents of retarded children to pool their resources through a mutual insurance trust, roughly similar to the original MARC Retardate Trust, ${ }^{204}$ whereby each parent's life insurance proceeds would be paid into a trust for the benefit of his child and the children of all other deceased meinber-parents. The fund would be administered by a board of trustees who would attempt to carry out the deceased parents' wishes for the future care of their retarded children, but the trustees would not themselves assume formal guardianship of the retarded beneficiaries. ${ }^{205}$ The public guardianship plan, which would provide formal guardianship, was not seen as inconsistent with the private trust arrangements if a particular child who was a beneficiary of the trust liad been accepted for service through a regional center.

Public guardianship existed on the county level in California at the time the committee began its work. Los Angeles County had been authorized by state legislation to establish an Office of Public Guardian in $1945 ; 206$ by the summer of 1967,45 of the 58 counties in the state had established public guardians. ${ }^{207}$ The existence of this guardianship

204. Treckell, MARC Retardate Trust-The First Five Years, in Proceedings or the Conference on Protective SÚpervision and Services for the Handicapped 60 (United Cerebral Palsy Associations, Inc., Nov. 15-17, 1966).

205. Those plans were discussed informally with representatives of CCRC at a meeting held in San Francisco, Sept. 25, 1965. References are to the transcript of proceedings, on file at the School of Law, University of California, Berkeley.

206. Ch. 907, \& 1, [1945], Cal Stat. 1690.

207. Material relating to the operation of the offices of the county public guardians is drawn from M. McKeany \& H. Taylor, Public Guardians and Welfare Services in California, Nov. 1970. This manuscript is the final report of a research project supported by the Social and Rehabilitation Service, U.S. Departinent of Health, Education and Welfare (CRD 365). We are grateful to Dr. McKeany and Dr. Taylor for their permission to refer to the manuscript. 
service was discussed by the committee at its first meeting. It was decided, however, not to pursue the possibility of using this resource, because the authority of the county guardians was limited to serving persons who were recipients of public aid or who were patients in a countyowned facility; ${ }^{208}$ most retarded persons did not fit either category. Moreover, the committee felt that the county guardians were primarily concerned with guardianship of the estates of their wards, while the committee wished to place its major effort into producing a plan that would provide meaningful guardianship of the person. The committee therefore determined to seek to establish a new guardianship resource, especially tailored to the needs of the mentally retarded.

At its first meeting, on February 24, 1966, the guardianship committee reviewed guardianship devices that had been developed in other states. A Parental Successor Law had been established in Washington State in 1959, which permitted the parents of "a person who is, or may become, a resident of a state school" to appoint a person or an institution to act as parental successor after his death, ${ }^{209}$ but the committee rejected this plan as being too limited in scope $e^{210}$ to serve as a model, and it was not considered further.

Perhaps the best known state guardianship plan for the retarded is that established in Minnesota under the auspices of the Commissioner of Public Welfare. The year before the committee began its work, the Minnesota plan had been critically evaluated after a careful field study and the point made that guardianship was too often used indiscriminately as a protective device without regard for its restriction of liberty and that some wards were not restored to competence promptly, even though they were eligible for discharge from guardianship. ${ }^{211}$ The committee hoped to avoid the large-scale use of guardianship that marked the Minnesota experience by precise statutory language that

208. Ch. 391, $\$ 4$, [1965] Cal. Stat. 1629, 1633 (former Welf. \& Inst'ns Code $\$ 5081$ ). The authority of the county guardians was recently extended to cover "any person in the county who requires a guardian or conservator and for whom there is no person or corporation qualified and willing to act in such capacity." CAL. ANN. WeLF. \& INst'NS CoDE $\$ 8006$ (West Supp. 1971) (effective July 1, 1969).

209. Ch. 126, [1959] Wash. Laws 659, codified at WaSH. Rev. Code AnN. $\S 72.33 .500$ (1962).

210. The parental successor assumed no financial obligation toward the child [id. $\$ 72.33 .580]$, but he had the right to "exercise an active and continuing interest in, and to be informed concerning the health, education, recreation, and general welfare" of, the person for whom he was named parental successor and to "take the person from the state school on visits, trips, or vacations the same as a parent." Id. $\$ 72.33 .550$. The supervisor of the Division for Handicapped Children of the State of Washington advised the Committee by letter dated March 7, 1966, that there had been "very limited usage" of the Parental Successor Law.

211. Levy, Protecting the Mentally Retarded, 49 MinN. L. Rev. 821, 834-38, 887 (1965). See also AlLEN, supra note 53, at 99-112. 
would provide more adequate guidance to courts in determining when guardianship was appropriate.

At the conclusion of its first meeting, the committee had tentatively decided to explore the possibility of creating a coinprehensive guardianship service that would afford a variety of plans to the parents of retarded children, be administered outside existing state agencies, and offer a personal service to retarded wards close to their place of residence. At its second meeting two inonths later, the committee considered a 15-page memorandum prepared by Priscilla Myrick of the project staff, which discussed the following issues: first, the need to determine eligibility for the guardianship program in such a way as to avoid unnecessary vagueness that might lead to the placement of well-intentioned but overly protective restrictions on some of the retarded persons involved; second, the decisions that must be made concerning (a) whether the program would be available only after the parents' death, as the present legislation provided; (b) whether lospitalized persons should be eligible for the service; and (c) whether the guardianship program should include estate management as well as personal care; third, the need to create a flexible guardianship system, as suggested by the President's Panel Task Force on Law; and fourth, the procedure necessary for establishing and terminating the guardian's authority. The meinorandum concluded with a proposal that would establish the Director of Public Health as the state guardian, and direct him to work through the regional centers by using "guardianship councils" established in eacli center. The actual work would be done by acting guardians in cooperation with social workers attached to the regional centers. Although it went through several changes in the drafting process, the final version of the guardianship bill was not far removed froin this initial proposal.

At this second meeting, a small drafting subcommittee was established to prepare a draft statute. ${ }^{212}$ Some issues encountered during the drafting process proved troublesome. Chief among those was the concept, originally proposed by the Task Force on Law of the President's Panel on Mental Retardation, of creating a modified system of

212. Members of the drafting subcommittee were Mrs. Vivian Walter, Chairman of the Guardianship Committee; Mr. Martin Dinkelspiel, a private attorney experienced in the legal problems of mentally retarded persons and their parents; Professor Herma Kay, Director of the project; and Mr. Edgar Pye, Assistant Director of the Golden Gate Regional Center. Mr. Leopold Lippman, Coordinator of Mental Retardation Programs, Mr. Frank O. Houston, Guardianship Administrator of the Department of Mental Hygiene, Mr. Jan Stevens, Deputy Attorney General, and Miss Priscilla Myrick of the project staff, also worked with the drafting subcoinmittee. References in the text to "the Project Staff" refer to Professor Kay and Miss Myrick, now Mrs. Peter Diamond. 
guardianship that would provide varying degrees of protection for persons afflicted with varying degrees of retardation. Spokesmen for the attempt to translate this idea into legislation were members of the project staff. Opponents at various times included most of the other attorneys on the subcommittee; their criticism, however, was directed at specific proposals, not at the effort to achieve flexibility. As one might expect, a compromise was ultimately obtained. Since others may encounter similar issues in attempting to establish public guardianship proposals, a detailed account of the subcommittee's deliberations follows.

The subcommittee's initial rough draft proposed the creation of the office of parental surrogate. The parental surrogate was to be appointed by the governor and charged with the care and protection of mentally retarded persons "who lack parental care and protection and who may be in public institutions, private institutions, foster homes, or otherwise." Persons eligible for the service included anyone who had been certified as mentally retarded by the superintendent of a state institution for the retarded, a regional center, or by competent medical or other testimony. The draft did not contain any specific proposals as to limited guardianship, but a notation indicated that this matter was yet to be worked out. The parental surrogate's basic method of operation was to be through the regional centers. Other sections dealt with the court hearing at which the parental surrogate was to be appointed, his annual reports to the court, and his discharge.

This initial draft was discussed at a second subcommittee meet$\mathrm{mg}$, and the project staff was asked to prepare a second draft that would spell out the idea of limited guardianship. The second draft renamed the parental surrogate as the personal surrogate and provided for his nomination to act by parents or guardians of eligible mentally retarded persons. It approached the idea of limited guardianship by providing that the personal surrogate be given two alternative types of appointments: either "general," conferring all powers normally held by a guardian, or "limited," conferring only those powers specifically detailed in the order of the appointing court. Limited appointments were not to be available for minors. This draft was accoinpanied by a memorandum arguing that limited guardianship was necessary to allow moderately and mildly retarded persons the utmost freedom their capacities allowed. Both the draft and the memorandum were presented to the full guardianship committee at its third meeting on June 6,1966 . In the ensuing discussion, the objection was inade that a court order of limited appointment detailing the guardian's powers would be a public document that highlighted the disabilities of the retarded ward. Moreover, it was argued that much of the concern over the civil rights of the 
ward was theoretical rather than practical in the sense that these civil rights could not actually be exercised. ${ }^{213}$ The sense of the full committee was that the draft should not contain a formal division between general and limited appointments, but that the drafting subcoinmittee should provide in the act for a general enumeration of the powers of the personal surrogate and the protection of the civil rights of the ward.

However, when the subcommittee presented its third draft, which abolished the general-limited distinction, at the fourth full committee meeting on September 7, 1966, the director of the Los Angeles Regional Center, Dr. Richard Koch, was present and persuaded the committee to reverse its prior decision: the drafting subcommittee was once again instructed to provide for the special needs of those mentally retarded persons who exist in a grey area between persons who can be maintained in the community with minimal help and those who are severely retarded and need the full scope of guardianship. The resulting major change in the fourth draft prepared by the project staff, was a provision outlining three levels of responsibility for the personal surrogate: First, he could be charged with the duty of acting as "advisor" for mentally retarded persons who request his advice and guidance, or for whose benefit his advice and guidance is requested by others. No court appointment would be necessary to authorize this service. Second, the surrogate could accept appointment as "protector" of the person or estate, or both, of "persons who are either borderline, mildly, or moderately mentally retarded and who need his assistance and protection, but who have not been judicially determined to be legally incompetent." This duty was contimgent upon court appointment, but the draft provided that the appointment itself would not abrogate any civil right otherwise possessed by the mentally retarded person if the protector consented to its exercise. Third, the surrogate might be appointed by a court as "guardian" of the person or the estate, or both, of a mentally retarded person judicially determined to be legally incompetent.

The fourth draft was made available to the public in a pamphlet, ${ }^{214}$ with an introduction stressing the independence of the personal surrogate from existing state agencies and his close comrection with the regional centers. The concept of linited guardianship was explained as follows:

213. This statement echoes the sentiments of many parents and judges. See notc 169 supra and accompanying text.

214. Commttee on Guardianship, California Mental Retardation Program and Standards Advisory Board, California Health and Welfare Agency, Guardianship: A Proposal for Lifetime Protection of the Mentally Retarded OF CALIFORNIA (Oct. 1966) [hereinafter cited as GuARDIANShIP]. 
Comprehensive guardianship-which places the retarded individual in the position of a ward, regardless of whether he is a child or adult - should be a service of the Personal Surrogate (state guardian) in every case where appropriate. For many retarded individuals, however, a more limited protective or counseling service is sufficient. This course would protect the civil rights of the retarded individual and would avoid placing him in the status of an incompetent person under the law. 215

Public hearings were held on the fourth draft in Los Angeles and San Francisco on Noveinber 2 and 3, 1966. ${ }^{216}$ In San Francisco, Dr. Elizabeth Boggs, Cochairman of the Task Force on Law of the President's Panel on Mental Retardation, outlined seven principles that must be taken into account in planning for guardianship services for the retarded. The principles were:

(1) There unust be a social institution that is primarily directed to the needs of the retardate's person, not his estate.

(2) There must be a public agency to assume responsibility when the family can no longer provide the necessary protection for its retarded members.

(3) The plan must be flexible enough to allow adaptation to the degree of disability of each individual.

(4) The protective function inust be available to the retarded person, regardless of where he is: admission to a hospital, for example, should not terminate this service.

(5) The guardianship role must be independent of the agencies that provide services to the retarded.217

(6) The procedure for appointment of the surrogate should be respectful of due process and should seek ways to provide meaningful review of the individual's capacities.

(7) The service of protection should be available to all who need it, without regard to age, or degree of retardation.

In Los Angeles, Professor Elyce Ferster, Codirector of the Mental Competency Study, commented more specifically in an analysis of the draft statute. She spoke favorably of permitting the surrogate to act as advisor without prior court appointment and of allowing the parents to nominate him prior to their deaths. She offered criticism of the notice and hearing provisions ${ }^{218}$ and predicted that they would become so

215. GUARDIANSHIP 3.

216. The hearings were jointly sponsored by the Mental Retardation Program and Standards Advisory Board and the California Council on Retarded Children and were attended by more than 500 persons. A transcript of Dr. Boggs' statement is on file with Professor Herma Hill Kay, Boalt Hall, University of California, Berkeley.

217. Dr. Boggs expanded this point to indicate her opposition to the proposal that the Personal Surrogate should operate through the regional centers. She feil that he should have his own staff, accountable directly to him.

218. Section 6 of the draft provided that a copy of the petition for appointment of the Personal Surrogate as Protector or Guardian should be personally served on the 
routine in practice as to make their protections ineffective. Finally, she was concerned whether the draft provision allowing the personal surrogate to consent to the exercise of civil rights by the ward might not result in a greater limitation of the ward's activities, rather than an expansion of his freedom.

Subsequently, a fifth draft, taking into account the views expressed at the two public meetings, was prepared by Professor Kay and circulated in December 1966. Its chief modification was to substitute the established role of "conservator" for the fourth draft's innovation of "protector" as the mechanism for providing limited guardianship. Conservatorship had been established in California in 1957 to provide an alternative to guardianship for adults who were not incompetent but who required a measure of supervision because of "advanced age, illness, injury, mental weakness, intemperance, addiction to drugs or other disability, or other cause."219 Since conservatorship did not imply legal incompetence, it seemed appropriate for use in this new context. A special provision allowed the use of the conservatorship statutes in the case of mentally retarded persons who were minors, although that necessary change was theoretically inconsistent with the idea that conservatees were legally competent. ${ }^{220}$

The surrogate's three functions thus were proposed by the fifth draft to be those of advisor, conservator, or guardian. Court appointment was not necessary for the surrogate to act as advisor. In order to distinguish the persons for whoin conservatorship would be appropriate from those for whom guardianship was required, the fifth draft directed the personal surrogate, when acting as conservator of the person, "to act as a wise parent would act in caring for his mentally retarded child and, in particular, to permit and encourage maximum self-reliance on the part of the conservatee." The provision relating to civil rights, which had been criticized by Professor Ferster, was eliminated.

proposed ward. If the ward was in a state institution, the draft provided that "the manner of service shall be decided by the court after consultation with the attending physician. ..." Section 7 required that the proposed ward be present at the hearing unless the appearance would be harmful to hin, or unless he was unable to attend by reason of physician inability. Both excusing circumstances were required to be evidenced by the affidavit or certificate of a physician or the medical director of any institution in which the proposed ward was a patient. GUARDIANSHIP supra note 214 , at 7.

219. Ch. 1902, § 1, [1957] Cal. Stat. 3306, 3307 (adding Probate Code $\S 1731$ ) See also Zillgitt, Planning for Incompetency and Possibilities and Practices Under the Conservatorship Law, 37 S. CAL. L. REv. 181 (1964). For a statement of the purposes of the new law as explained by the California State Bar, see Fourth Progress Report to the Legislature by the Senate Interim Judiciary Committee, 1 Appendix to the Journal of the California Senate 487 (reg. Sess. 1957).

220. Cal. AnN. Health \& Safety Code $\$ 416.9$ (West 1970). 
Following the committee's December meeting, technical changes were made in the fifth draft and a new means was devised to guarantee that evidence of a retarded person's current condition would be available to the court appointing the surrogate to act as guardian or conservator. The draft provided that a complete medical evaluation must be available, including a report prepared by a social worker or psychologist of the retarded person's current mental condition and social adjustment. If a medical affidavit had been filed indicating that the retarded person was unable to attend the hearing, the social worker or psychologist who had assisted in preparing the report for the court was required personally to "visit the alleged mentally retarded person and be prepared to testify as to his present condition." Despite Dr. Boggs' contrary view, the sixth draft continued its direction that the personal surrogate's services as advisor, guardian, or conservator of the person be performed solely through the regional centers. The surrogate's services as guardian or conservator of the estate might be contracted out to a regional center, the Department of Mental Hygiene, the public guardian of a county, or a private corporation authorized to perform such services.

The provisions of the sixth draft were submitted to the California Legislative Counsel's office to be put into the proper form for submission to the legislature. That office made a draft available on January 3 , 1967. Although the proposal was subjected to many changes before it was enacted in 1968, the chief work of the drafting subcommittee had been completed when the sixth draft was put into bill form. The remaining period of time from January 3,1967, when the draft came from the Legislative Counsel's office, to August 8, 1968, when the final version of the bill was approved and filed, was occupied with presenting the bill to the legislature. ${ }^{221}$

Major opposition to the proposed legislation came in the form of efforts to avoid the creation of a new office of personal surrogate through expansion of existing, related services. The impetus for this attitude was twofold: the lobbying activities of the California Coroners and Public Administrators Association, representing the county guardians, ${ }^{222}$ and the fiscal policies of the new governor, Ronald Reagan,

221. The members of the drafting subcommittee and the Guardianship Committee were active as individuals in this effort.

222. Of the 45 counties having Public Guardians in 1967, 38 are known to consoldate this office with another county office, and 26 counties join it with the office of Public Administrator. M. McKeany \& H. Taylor, supra note 207, at 91-94, 104-13. The Coroners and Public Administrators Association thus represented the interests of the County Public Guardians, arguing that they were authorized, qualified, and experienced in providing the service that the Committee wished to provide through the Personal Surrogate. The Association recommended that the County Guardians be 
who took office in $1967 . .^{223}$ As a result, the draft proposal was referred for interim study, ${ }^{224}$ and a hearing was held on January 17, 1968 , before the Subcommittee on Judiciary of the Senate Interim Committee on General Research. ${ }^{225}$

named instead as advisor, guardian, or conservator of mentally retarded wards and bo allowed to rely on the regional centers for assistance in carrying out this program.

The County Guardians did act for some mentally retarded persons, primarily those who were recipients of public aid. A study of the California county guardians prepared in 1970 studied the caseloads of eight county guardians intensively. Of the 1046 wards who were supervised by these eight public guardians on January 1, 1968, 223 were classified as mentally retarded. Id. at 607 . (The eight counties studied intensively were Sacramento, San Diego, Alameda, Santa Clara, Orange, Santa Cruz, Stanislaus, and Napa. Id. at 368-83.) All but one of these 223 wards were receiving or expected to receive Aid to the Disabled or were receiving Indigent Aid until the guardian could reach their assets or seek income from other sources for them. Id. at 611 . The county guardians' present authority to act for "any person in the county who requires a guardian or conservator and for whom there is no person or corporation qualified and willing to act in such capacity" was not granted by the legislature until 1969 [CAL. ANn. Welf. \& INST'NS CODE $\$ 8006$ (West Supp. 1971)], the year after the public guardianship bill had been enacted. Indeed, since the mentally retarded persons served through the regional centers do have a corporation-the Department of Public Health-qualified and willing to act as guardian or conservator under the provisions of the 1968 legislation, it would appear that the county guardians are not authorized to seek appointment to act for these retarded persons under present law.

223. During January of 1967 the guardianship proposal was presented to Spencer Williams, the Administrator of the Health and Welfare Agency, as a major recommendation of the Mental Retardation Program and Standards Advisory Board. At an informal meeting held between representatives of the Health and Welfare Agency, the Department of Public Health, and the Guardianship Committee on March 23, 1967, it was made clear that Governor Ronald Reagan, who had been elected Governor of California in November, 1966, would not support any new programs during 1967. Alternatives, such as the use of existing machinery like the county public guardians, were proposed. It was finally agreed that the guardianship proposal would be subunitted to the Legislature as a Senate Bill; that the bill would be referred to the Senatc Judiciary Committee for interim study; and that a stopgap measure would be prepared allowing the Department of Public Health (rather than its Director, as provided by the law enacted in 1965) to be appointed guardian of the mentally retarded and authorizing the Department to contract for the performance of these duties by the regional centers where they existed, and by other units of local government (such as the county guardians) where regional centers were unavailable.

224. S.B. 969, containing the draft proposal, was referred for interim study on May 11, 1967. S.B. 1461, a companion stopgap measure discussed in note 223 supra, unexpectedly was also referred for interim study, largely through the opposition of the Coroners and Public Administrators Association.

225. The agenda included the following witnesses: (a) in support of S.B. 969: Dean Neil D. Warren, Chairman of the Mental Retardation Program and Standards Advisory Board; Mrs. Vivian Walter, Chairman of the Guardianship Committec and inember of the Board; Professor Herma Hill Kay; Mr. Stanley LeBon, President of the California Council on Retarded Children; Mr. Frank Gibson, Supervisor of San Diego County; Mr. Martin Dinkelspiel, member of the San Francisco Bar; and Mr. Wendell T. Handy, Secretary, Board of Education, Compton Elementary School District; (b) in opposition to S.B. 969: Mr. Baldo Kristovitch, Public Guardian of Los Angeles County; Mr. Con Shea, Public Guardian of San Francisco County; Mr. George Neilson, Public Guardian of Sacramento County; Mr. William Meyer, Publie Guardian 
Following the hearing, the guardianship committee learned that it had not made a persuasive case establishing the need for the personal surrogate's office as a new state agency. ${ }^{226}$ The committee therefore decided to abandon its efforts in this regard and resolved instead to recommend that the Director of Public Health, already charged with the responsibility of contracting for the regional centers, ${ }^{227}$ should also take responsibility for the guardianship program. The committee believed that the opposition of the county guardians would not be sufficient to defeat a bill cast in this form. ${ }^{228}$

In addition to substituting the Director of Public Health for the personal surrogate, the final draft included a major change in eligibility: the guardianship services were to be available only to mentally retarded persons eligible for the services of a regional center and mentally retarded patients in a state hospital who lad been admitted or committed to the hospital froin a county served by a regional center. The subcommittee thought these new eligibility requirements would result in tying the administration of the program tightly to the regional centers and aid in speeding their establishment throughout the state. The Mental Retardation Program and Standards Advisory Board were charged with adopting policy guidelines for the Director of Public Health's use in carrying out his duties under the bill, and the director was to adopt rules and regulations consistent with the policy guidelines. The provisions of this final draft were incorporated into S.B. 1159,

of Santa Clara County; and Mrs. Bess Hearne Toretsky, appearing individually. In addition to these witnesses, Mr. Leopold Lippman, Coordinator of Mental Retardation Services, had been authorized to state that the Health and Welfare Agency favored S.B. 969. Mr. Frank O. Houston, Guardianship Administrator of the Department of Mental Hygiene, informed the Committee of his Department's services as Guardian of the estate for state hospital patients who needed this service.

226. This point was made in a meeting on February 8, 1968, between the Committee and Mr. R. Blair Reynolds, Counsel for the Judiciary Committee.

227. Ch. 1242, § 1, [1965] Cal. Stat. 3106 (former Health \& Safety Code § 415.2), For the subsequent changes in this section after enactment of the Guardianship Law, see note 233 infra.

228. The committee's conclusion was based in part on a passage from a preliminary report prepared by the Judiciary Committee's counsel, R. Blair Reynolds. The report was never published; but the passage indicated that there were two main problems with the position of the county guardians:

(1) As we are extremely mobile as a Society, the ward may be in a county other than that whose Public Guardian was previously nominated at the death of his parents, or the ward might be best advised to move to another county later due to the better job opportunities, service available, etc. In either case, utilization of a county guardian would necessitate a transfer of guardianship, which is undesirable as a frequent occurrence. Also, such a move might take the retarded person into a county where there is no Public Guardian. (2) The guardian himself should have some knowledge of the specialized requirements of the mentally retarded, and while Public Guardians in the large counties do have such knowledge, this is not a general characteristic. Their expertise more specifically relates to guardianship of estates. 
which was introduced on April 16,1968, by Senators Clair Burgener, Donald Grunsky, and George Moscone. It was enacted without substantial change and was approved and filed on August 8, 1968. ${ }^{220}$

Mr. Martin Dinkelspiel, a committee member, later published an article explaining the objectives of the new law and the possibilities it made available to parents of mentally retarded persons for legal planning. ${ }^{230}$ The article explained the concept of the regional centers as well as the technical provisions of the law and served the necessary purpose of informing the state's attorneys about this new legal tool.

\section{Realization of Public Guardianship for the Mentally Re- tarded: The Regional Centers}

As we liave seen, the regional centers were autliorized in 1965 under the leadership of Assemblyman (now Congressman) Jerome Waldie's Assembly Subcommittee on Mental Health Services. ${ }^{231}$ The legislation creating the regional centers declared that "[i]t is desirable that there be a shift in state responsibility for mentally retarded persons from the time they enter a state hospital to the time when they are diagnosed as needing specialized care."232 The regional centers were a new departure in state financed services: the state Department of Public Health was authorized to contract with appropriate agencies for the establishment of regional centers. ${ }^{233}$ The department negotiated contracts for the first two regional centers with two private agenciesChildren's Hospital in Los Angeles, serving Los Angeles County, and San Francisco Aid to Retarded Children, serving the five Bay Area counties of San Francisco, Alameda, Marin, Contra Costa, and San Mateo. Services provided by the regional centers included diagnosis, counseling, maintenance of a registry and case records, follow up services, assistance in hospital placement where necessary, calling attention to unmet needs in community care and services for the retarded, maintaining appropriate staff, and-inost innovative of all-providing state funds to vendors of service to the retarded when failure to provide such services would result in state hospitalization. ${ }^{234}$ The regional centers were

229. Ch. 1099, [1968] Cal. Stat. 2108, codified at Cal. AnN. Health \& SAFETY CODE $\$ \S 416-16.20$ (West 1970).

230. Dinkelspiel, Recent Legisiative Acts for the Benefit of the Mentally Retarded, 44 CAL. ST. B.J. 219 (1969).

231. See notes 180-82 supra and accompanying text.

232. Ch. 1242, § 1, [1965] Cal. Stat. 3106 (former Health \& Safety Code $\$ 415.1$ ), amended and renumbered [omitting the quoted language] CAL. ANN. HeAlTH \& SAFETY CODE $\$ 38100$ (West Supp. 1971).

233. Id. (former Health \& Safety Code $\S 415.2$ ), renumbered, CAL. ANN. Health \& SafeTY Code $\$ 38101$ (West Supp. 1971).

234. Id. (former Health \& Safety Code $\$ 415.4$ ), renumbered, CAL. ANN. HEALTH \& SAFETX CODE $\$ 38106$ (West Supp. 1971). 
thus initially private agencies that, through contracts with the Department of Public Health, became conduits for state funds used to purchase services for mentally retarded persons. ${ }^{235}$

During the time the guardianship proposal was being considered, the regional centers were growing in public acceptance. For the first 30 months of operation, January 1966 to July 1, 1968, 2,898 requests for service were made to the two regional centers. The centers accepted and registered 1,003 of these persons as appropriate for regional center service; by the end of June 1968, 770 of these persons had received services. ${ }^{236}$ As of December 1, 1971, the total regional center caseload exceeded 5,000 persons. ${ }^{237}$ Because of the close relationship between the regional center and its clients-the centers originally terminated service only upon a chent's death, his admission to a state residential facility, or his having moved out of the area served by a center ${ }^{238}$ - the guardianship committee believed that the centers offered the best location for actual performance of the personal service of guardianship or conservatorship of the person. As we have seen, the final version of the legislation requires the Director of Public Health to perform his duties as advisor or guardian or conservator of the person solely through the regional centers. ${ }^{239}$

235. Address by E. Pye, California's Regional Centers, to participants in the Public Health Social Work Institute, University of California, Berkeley, June 1967, at 4 [liereinafter cited as Pye]. The enthusiasm for this new concept was sucli that Mr. Pye, Assistant Director of the Golden Gate Regional Center, told participants "never before have I seen an infant program born which was believed to be the salvation and the redemption of all probleins heretofore unresolved in the field of mental retardation!"

Mr. Pye cautioned, however, that unless it was clearly understood that the regional centers' services were merely supplementary to those already being provided by education, social welfare, reliabilitation, public health, mental hygiene, and other public and private agencies, people would come to view the regional centers

as the answer, the solution, and the responsible agency in the community to provide services to the mentally retarded and their families. We would thus lave the segregated service for the already segregated population that was the dilemma of the state hospitals for the retarded.

Id. at 6-7. There was some feeling that the regional centers were created without adequate planning for how their operation would conflict with existing local facilities. See alameda County Mental Retardation Service, A Critique of the Regronal CENTER CONCEPT (1968).

Mr. Pye produced a revised form of this address, reflecting the operation of the regional centers as of Jan. 1, 1970. The pamplilet is available from the Bureau of Mental Retardation Services, State Department of Public Healtl, 2151 Berkeley Way, Berkeley, Calif. 94704.

236. A Proposal, supra note 181, at app. A.

237. Letter from Dr. Cliarles R. Gardipee, Chief of the Bureau of Mental Retardation Services, Department of Public Health, to Professor Herma Hill Kay, Dec. 21,1971 . The authors are grateful to Dr. Gardipee for kindly supplying this information.

238. Pye, supra note 235 , at 8 .

239. Cal. ANN. Health \& SAfety CODE $\$ 416.19$ (West 1970), See also Dinkelspiel, supra note 230, at 227. 
Use of the guardianship plan by parents of the mentally retarded is gradually increasing. Table 22 shows the number of nominations received by the regional centers from 1969 through $1971 .^{240}$ These nominations are typically made in the form of codicils to the will of a parent; the present policy of the Department of Public Health is to refuse to seek appointment while a parent or guardian of the retarded person is alive. ${ }^{241}$ One of the three appointments of the director as guardian that liave so far been formalized by court action, however, does involve a situation where a parent is living. The ward is a 16-year-old mentally retarded girl whose mother has been committed to a state hospital for the mentally ill and is not considered eligible for early release. The girl's sister is in a hospital for the retarded in Canada. Guardianship was thought to be necessary because the girl's grandmother died, leaving a trust to care for the girl, her sister, and her mother, and because the girl liad other funds in her own name that could not be spent without a guardian's appointment. ${ }^{242}$

Table 22. Guardianship Nominations.

\begin{tabular}{rc}
\hline Year & Number \\
\hline 1969 & 17 \\
1970 & 59 \\
1971 & 113 \\
\hline Total & 189 \\
\hline
\end{tabular}

The department's policy of refusing appointment during the life of a parent or private guardian is based on a belief that parents should contimue to participate in the planning for their retarded children as long as they are capable of doing so. This policy realizes the original purpose of the decision to establish public guardianship in California: the idea was not to replace the parents' central role in the decisionmaking process, but rather to offer parents a resource that would take effect after the parent could no longer act. It is too early to evaluate the dayto-day operation of this program. Future studies will be needed to determine whether California has succeeded in fashioning a legal tool that will adequately respond to the "poignant and challenging question . . . of the parent: 'What will happen to my retarded child when I am no longer able to care for him?" "243

240. Letter, supra note 237; id. May 7, 1971; telephone conversation, Feb. 18, 1972. Of the 189 nominations, one has been withdrawn and three have been acted upon by court appointment, leaving a total of 185 nominations in effect as of Dec. 1, 1971.

241. Letter, supra note 237.

242. Id.

243. THE UNDEVELOPED ReSOURCE 77. 


\section{IV}

\section{State-wide Legal Planning for Mentally Retarded Persons in California}

\section{A. The Lanterman Mental Retardation Services Act}

On July 1, 1971, when the Lanterman Mental Retardation Services Act of $1969^{244}$ became fully effective, much of California's law and practice affecting the mentally retarded was altered. The purpose of the Lanterman Act is to create a system of facilities throughout the state "which is so complete as to meet the needs of each retarded person, regardless of age or degree of handicap, and at each stage of his life's development." 245 The state has been divided into 13 Mental Retardation Planning Areas, each served by an Area Planning Board composed of parents of the mentally retarded, professionals who work with the retarded, and members of the general public. ${ }^{246}$ These area boards are charged with the task of developing an area plan, specifying ways and means "to ensure the provision of service . . . in such a manner as to avoid duplication, fragmentation of service, and unnecessary expenditures."247 Area plans are submitted to the Areawide Comprehensive Health Planning Agency and, through that body, to the Statewide Health Planning Council. ${ }^{248}$ The Lanterman Act also creates a State Mental Retardation Program Advisory Board, supplanting the old Mental Retardation Program and Standards Advisory Board, charged with advising the Health Planning Council, the Secretary of the Human Relations Agency, the governor, and the legislature on the "initiation, coordination, and implementation of programs and projects for the mentally retarded."249

The regional centers are the most important part of the Lanterman Act. Ten regional centers are presently in existence, and three additional centers have been authorized..$^{250}$ The Lanterman Act has greatly expanded the role of the regional centers. The most striking change is that since July 1,1971 , except for mentally retarded persons who may be placed in state hospitals pursuant to the Lanterman-Petris-Short Act

244. Ch. 1594, § 14, [1969] Cal. Stat. 3234 (adding Health \& Safety Code $\S \S 38000$ $38300)$.

245. CaL. ANN. HEalth \& SAfety CODE $\$ 38001$ (West Supp. 1971).

246. Id. §§ 38050-63; CaLIforna Human Relations Agency, Lanterman MeNtal Retardation Services Act 9 (1971). The Human Relations Agency has replaced the old Health and Welfare Agency. See also note 257 infra.

247. CAL. ANN. Health \& SAFETy CODE $§ 38058$ (West Supp. 1971).

248. Id. $\$ 38060$.

249. Id. $\S 38202$.

250. California Human Relations Agency, supra note 246, at 5-7; letter, supra note 237; ch. 501, 1 [1971] Cal. Stat. 538. 
dealing with the mentally disordered, ${ }^{251}$ "no mentally retarded person shall be admitted to a state hospital except upon the referral of a regional center." ${ }^{252}$ Moreover, the regional centers are now charged with the responsibility of accepting referrals of all mentally retarded persons discharged from the state hospitals. ${ }^{253}$ Nor will the hospitals be allowed to avoid this provision by the practice of granting extended leaves of absence to patients who hive in the community but are not technically discharged from the hospital: the Act eliminated leaves of absence after July 1, 1971, except for home visits not exceeding 60 days. ${ }^{254}$

The practical effect of these changes, which have placed the regional centers in charge of the hospital admission process, will be to greatly decrease the use of state hospitals as long-term residential facilities for the mentally retarded. This, indeed, was a chief purpose of the new Act; the background study that preceded the legislation found excessive rehance on the state hospital system as a place of first resort, rather than last resort, for many families. ${ }^{255}$ The study proposed to discourage this use of the state hospitals by creating, and mobilizing through the regional centers, a network of community services that would provide realistic alternatives to long-term hospital care. Financmg is to be provided by the state, utilizing the maximum available federal funds, relying on minimal county participation, and mitiating a system of family contribution to the cost of out-of-home services furnished to children under 18 , the exact amount to be dependent upon each family's ability to pay, but not exceeding the cost of caring for a normal child at home. ${ }^{256}$

A pamphlet explaining the aims of the Lanterman Act states the revised role of the state hospitals for the retarded to be that of providing

a) Short-term respite care, emergency care, professional training, demonstration projects, and specialized medical care.

b) Specialized limited-term programs for habilitation, socialization, and vocational training.

c) Medical supervision and full-time nursing care for the profoundly retarded, the nonambulatory, and other individuals with special needs. ${ }^{257}$

251. Cal. ANN. Welf. \& INsT'NS CODE $\$ \S 5000-5401$ (West Supp. 1971).

252. CaL. ANN. HEALtH \& SAFETY CODE $\$ 38103$ (West Supp. 1971).

253. Id. Persons who had been committed to Sonoma prior to July 1, 1971, are referred to the Community Services Branch of the Department of Social Welfare upon their discharge.

254. Id. \$ 38004 .

255. A Proposal 8-9.

256. Id. at 18-19.

257. California human Relations agency, lanterman mental Retardation 
This strict limitation of the state hospitals to the provision of medical, rather than residential, care is consistent with the current general view that the mentally retarded should be maintained in the community wherever possible. ${ }^{258}$

\section{B. Impact of the Lanterman Act on Prior Law and Practice}

\section{Hospital Admission}

The new responsibility of the regional centers in the hospital admission process has, of course, laad a significant impact upon the role of the local hospital agents described in part I of this Article. ${ }^{259}$ In some areas, such as the five San Francisco Bay Area counties served by the Golden Gate Regional Center, the local agents have been entirely replaced by the regional center staff. The mentally retarded are the chients of the regional centers, whose personnel have responsibility for finding appropriate programs for them, whether in the hospital or in the community. According to Mr. Edgar Pye, Director of the Golden Gate Regional Center, the state hospitals are presently in a transition stage between a traditional hospital orientation and a more modern prograin orientation. ${ }^{200}$ Sonoma State Hospital, for example, now offers 11 different programs. ${ }^{201}$ A mentally retarded person is no longer placed permanently in the hospital; he is there for a specific program, such as Sonoma's Program for Plyysical and Social Development of Children Under Twenty-One. If that prograin becomes imappropriate, the regional center consults with the family and with Sonoma personnel in deciding what other program, imside or outside the hospital, would be more appropriate. Perhaps the most significant change made by the Lanterman Act is the continuity of planning and supervision offered to each mentally retarded person and his family through the regional centers. Formerly, a mentally rctarded person placed in a state hospital ceased to be the responsibility of any community agency. Under present practice, the mentally retarded person who goes to the state hospital goes as a regional center client, is there treated as a regional center cli-

SERvices ACr, question 12 (1971). [This pamphlet is a different document from the booklet cited in note 246 supra, although both were prepared at the same time by the Human Relations Agency. The pamphlet is a fold-out brochure containing a list of 29 questions and answers about the Lanterman Act. The booklet is in narrative form.]

258. Bramwell, Changing Concepts of Residential Care, in I. Philips, supra note 12 , at 334, 335-36. Indeed, some authorities liave urged strongly that a place in the community can be found for every patient presently in the state hospitals. E. KATZ, The Retarded Adult in the COMmUNity 245 (1968).

259. See part $I(B)(1)$ supra.

260. Telephone conversation with Mr. Edgar Pye, Dec. 28, 1971.

261. Id. Some of these programs are the following: Physically Handicapped with Chronic Illness (under and over 15 years); Sensory Handicapped; Behavior Modification (under and over 15 years); and Social Development (young adults). 
ent, and remains a regional center client upon his return to the community.

A critical factor in the current period of adjustment is the relationship established between the regional centers and the state hospitals for the mentally retarded in determining eligibility standards for hospital admission. The extent to which the state hospitals can legally control their own admissions since July 1,1971 , is not entirely clear. Welfare and Institutions Code section 6509,262 which was discussed earlier in the context of the division of authority between the hospitals and the courts, ${ }^{263}$ and which allows the Department of Mental Hygiene to reject a person committed to its care by a court if the person is not "suitable for admission," has not been amended or repealed by the Lanterman Act. On the other hand, court commitment of the mentally retarded will be greatly restricted under the Lanterman Act, ${ }^{264}$ and section 6509 appears limited to court commitments. In other cases, the state hospitals are required to admit persons "duly committed or transferred" to them "in accordance with law."265 A newly admitted patient has not been "transferred" to the hospital; "transfer" is a word that appears limited to the authority to move patients froin one state lospital to another. ${ }^{206}$ And, although the Lanterman Act provides that no mentally retarded person can be admitted to the hospital without the regional center's recommendation, it does not require that the person must be accepted for care by the hospital if the recommendation is made. ${ }^{267}$ Our conclusion is that the Department of Mental Hygiene retains the right to control its own admissions, at least to the extent of setting priorities if there is a waiting list and probably to the extent of rejecting an applicant it considers unsuitable for hospital treatment.

If this conclusion is sound, the regional centers now find themselves in a functional position similar to that formerly occupied by the committing court: a position of dependency on the hospital's policies. The Lanterman Act charges the regional centers both with the task of offering alternatives to state hospital placement and of recommending placement in the state hospitals. Although these tasks are not neces-

262. CAL. ANN. WeLf. \& INST'NS CODE $\$ 6509$ (West Supp. 1971).

263. See text following note 66 supra.

264. See text accompanying notes 272-331 infra.

265. CAL. ANN. WeLf. \& INST'NS CODE $\$ 7507$ (West Supp. 1971).

266. See id. $\$ 7514$.

267. CaL. ANN. Health \& SAFETY CODE $\$ 38103$ (West Supp. 1971); patients admitted pursuant to the Lanterman-Petris-Short Act are exempt from this requirement. See text accompanying note 251 supra. The subcommittee, however, may have intended that the regional centers control the entire admission procedure. Its study states flatly that "[t]he Regional Centers will be required to do all screening for admission to the State Hospitals for the Mentally Retarded." A Proposal 14. 
sarily inconsistent, their performance may be complicated by the departmental separation of the regional centers, which are under the jurisdiction of the Department of Public Health, from the state hospitals, which are under the jurisdiction of the Department of Mental Hygiene. Communication difficulties may develop, particularly if the local agents continue to exist and function in a structure parallel to that of the regional centers. This mcipient conflict may be exacerbated by the Lanterman Act's indication that efforts inay be made to obtain federal consent to transfer programs and, therefore, funds for the retarded from other state departments to the Department of Public Health. ${ }^{288}$ An earlier effort, in 1968, to transfer control of the regional centers from Public Health to the Department of Mental Hygiene was narrowly averted and aroused some fears among parents' groups. Governor Reagan's 1972 budget promises to exacerbate the situation by proposing that all funds for the retarded be budgeted to the Department of Mental Hygiene, then to be reallocated by that department to the Department of Public Health, the Department of Social Welfare, and any other departinent that operates programs for the retarded. ${ }^{269}$ This policy of granting fiscal management to the Department of Mental Hygiene while charging the Department of Public Health with the primary responsibility for the retarded through the regional centers seems unsound and inconsistent with the goals of the Lanterman Act of providing a unified system of delivering services to the retarded. Hopefully, it will not be accepted by the legislature.

An effort has been made to provide an institutional means of cooperation between the regional centers and the state hospitals. Each regional center has been allocated a new staff position at a supervisory level, carrying the title of Hospital Liaison Coordinator. ${ }^{270}$ It is the responsibility of the coordinator to work closely with the state hospitals in making decisions affecting the mentally retarded clients of the regional center who will participate in one or nore of the hospital's programs. Although the hospital may technically retain final authority over its admissions, ${ }^{271}$ a coordinator who is thoroughly familiar with the hospital's programs and with the needs of the retarded client should be able in effect to make the placement decision a joint one. Local working arrangements of this sort should lielp to smooth departmental rivalries so that the retarded inay realize the Lanterman Act's promise of more effective service.

268. Cal. AnN. Health \& Safety CODE $\$ 38250$ (West Supp. 1971).

269. State of California, Governor's Budget 1972, at 132-34, L-33 (State Printing Office, Sacramento, Calif. 1972). The proposed change has been protested by parents of the mentally retarded in the San Francisco Bay Area. San Francisco Chronicle, Feb. 4, 1972, at 3, col. 3.

270. Telephone conversation, supra note 260.

271. See text accompanying notes 262-67 supra. 


\section{Court Commitment}

Having placed the regional centers in the midst of the hospital admission procedures, the Lanterman Act completed its reforms by removing the courts to the periphery of that process. Since July 1, 1971, no mentally retarded person may be judicially committed to the Department of Mental Hygiene unless he is "a danger to himself or others."272 The routine use of courts as a normal part of the hospital admission procedure, described in part I of this Article ${ }^{273}$ has thus come to an end in Califorma for the mentally retarded, as it had earlier come to an end for the mentally ill. ${ }^{274}$

This is a novement in a progressive direction. As we have seen, neither the hospital agents who assisted the families at the hearing, the judges who presided over the hearings, nor the families themselves had a clear understanding of why court commitment was necessary or helpful in the case of mentally retarded minors whose parents were petitioning for hospital admission. The legislature provided in 1967 that unlawfully or improperly contriving to have a person adjudged mentally retarded in order to obtain a commitment to a state hospital is a misdemeanor, ${ }^{275}$ but the real problem seems rather to be that parents agree to hospitalization when their child could be maintained in the community were adequate resources available. Shifting the screening device from the court to the regional centers may help solve this problem, since the regional centers are charged, as the courts were not, ${ }^{270}$ with developing alternatives to hospitalization. Welcome as the abolition of court commitment as a prerequisite to hospital admission may be, however, the Lanterman Act's substituted procedure is nevertheless open to some criticism. Two problems deserve notice: the new standard for judicial commitment and hospital admission of the mentally retarded adult. Each of these issues will be discussed briefly.

a. The dangerousness standard. The new standard for judicial commitment of the inentally retarded-that of danger to self or to otherswas previously applied to commitments of the mentally ill in California and is still in use elsewhere. ${ }^{277}$ Until 1969, one of the two basic commitment sections in California applied to mentally ill persons "[w]ho are of such mental condition that they are dangerous to themselves or the person or property of others, and are in need of super-

272. Cax. ANn. Welf. \& INsT'Ns Code $\$ 6500.1$ (West Supp. 1971). See also CAL. ANn. Health \& Safety Code $\$ 38002$ (West Supp. 1971).

273. See text accompanying notes 84-105 supra.

274. See authorities cited notes 114-15 supra.

275. CAL. ANN. WeLF. \& INST'NS CODE $\$ 6511$ (West Supp. 1971).

276. See Table 6 supra and preceding text.

277. For example, Arizona. See Special Project, The Administration of Psychiatric Justice: Theory and Practice in Arizona, 13 ARIz. L. REv. 1, 96-117 (1971). 
vision, treatment, care or restraint."278 In recommending that this standard be abolisled for all noncriminal mental patients, the Assembly Subcommittee on Mental Health Services relied on a study prepared for its use that criticized and rejected the "dangerousness" test. ${ }^{279}$ The subcommittee found that although the commitment law distmguishes between the dangerous and nondangerous mentally ill,

most commitment courts do not concern themselves with this distinction, consider it a legal formality, and generally commit citizens on the sole ground of a finding of "mental illness." 280

The subcommittee's solution, now embodied in the LantermanPetris-Short Act, authorizes a 72-hour detention for evaluation and treatment of a person who, "as a result of mental disorder is a danger to others, or to himself, or gravely disabled," upon certification of a peace officer, a staff member of designated facilities, or designated professionals. ${ }^{281}$ Alternatively, a court may order that such a person be held for evaluation ${ }^{282}$ for no longer than 72 hours. ${ }^{283}$ Following the evaluation, a person may be certified by a participating physician and the professional person (or his designee) in charge of the facility where the evaluation was performed, ${ }^{284}$ for 14 days of involuntary treatment if the professional staff has found him to be a danger to himself or others, or gravely disabled, as a result of mental disorder; if he refuses to accept voluntary treatment; and if the facility is appropriate for lis treatment and agrees to admit lim. ${ }^{285}$ At the end of the 14-day period, the patient may not be further detained unless he has threatened, attempted, or inflicted physical harm upon another at the time he was originally taken into custody or during his treatment period and presents "an imminent threat of substantial physical harm to others."286

The background study explained the purpose of these provisions as permitting imvoluntary custody and treatment of persons who had been proven to be dangerous, while preventing the detention of persons who might potentially be dangerous. ${ }^{287}$ Pointing to the questionable

278. Ch. 391, \& 5, [1965] Cal. Stat. 1629, 1654 (former Welf. \& Inst'ns Code § 5500), amended, ch. 798, \& 1, [1968] Cal. Stat. 1540; ch. 1374, § 61.5 [1968] Cal. Stat. 2635, 2664; repealed, ch. 1441, \& 2, [1968] Cal. Stat. 2841 (all effective July 1, 1969).

279. A BACKGROUND DOCUMENT, supra note 114 .

280. Id. at 18. See also R. Rock, Hospitalization and Discharge of the MenTALLY ILL 121-71 (1968).

281. CAL. ANn. Welf. \& INST'NS CODE $\S 5150$ (West Supp. 1971) (effective July 1,1969 ).

282. Id. $\$ 5200$.

283. Id. \& 5206 .

284. Id. \&5251.

285. Id. $\$ 5250$. See also cases cited note 117 supra.

286. Cal. ANN. Welf. \& INST'Ns CODE $\$ 5300$ (West Supp. 1971). See also id. $\S 5254$.

287. A BaCkground Document 143. 
validity of psychiatric predictions of dangerous behavior, the study concluded that

when a person who has committed no dangerous act is kept in a closed facility because he might be dangerous to society in the future, this is preventive jailing. We may call the facility a hospital or treatment center, but to the man locked inside it is a jail. ${ }^{288}$

The new commitment provision in the Lanterman Mental Retardation Services Act seeins to rely on a similar distinction between proof of danger and mere potential for danger:

After July 1, 1971, mental retardation alone shall no longer constitute sufficient justification for judicial commitment. Instead, mentally retarded persons shall receive services pursuant to this division. Mentally retarded persons who constitute a danger to themselves or others may be judicially committed if evidence of such danger is proven in court. ${ }^{289}$

This provision, found in the Health and Safety Code, was part of the original Lanterman Act of 1969. In 1970, Assemblyman Lanterman introduced Assembly Bill 1384, which made several changes in the Lanterman Act provisions included in the Health and Safety Code and added the following provision to the Welfare and Institutions Code:

On and after July 1, 1971, no mentally retarded person inay be committed to the Department of Mental Hygiene pursuant to this article, unless he is a danger to himself or others. ${ }^{200}$

This provision does not contain the safeguard, found in the earlier Health and Safety Code provision, that evidence of the danger to self or others inust be proven in court. The omitted language may be considered mere surplusage, since all court orders must be based on proof. Yet the subcommittee's earlier finding that courts committing mentally ill persons set small store by the "dangerousness" standard ${ }^{291}$ is troublesome. The Assembly Subcommittee on Mental Health Services was the source both of the Lanterman-Petris-Short Act and of the Lanterman Mental Retardation Services Act. The careful attention given by the subcommittee to the problem of civil commitment of the mentally ill, however, does not appear to have been duplicated in its work on civil commitment of the mentally retarded. Neither the background study prepared for the Lanterman $\mathrm{Act}^{202}$ nor its explanatory litera-

288. Id. at 145 (emphasis in origmal). See also Beaver, The "Mentally Ill" and the Law, 1968 UTAH L. REv. 1 (1968); Dershowitz, Psychiatry in the Legal Process, 4 TRIAL 29, 32-33 (1968); Livermore, Malmquist \& Meehl, On the Justifications for Civil Commitment, 117 U. PA. L. Rev. 75, 81-83 (1968); Special Project, supra note 277.

289. Cal. ANn. Health \& Safety Code $\$ 38002$ (West Supp. 1971).

290. Cal. ANn. Welf. \& INST'NS Code $\$ 6500.1$ (West Supp. 1971).

291. See text accompanying note 280 supra.

292. See note 181 supra. 
ture $^{293}$ give any indication of the policy underlying these new commitment sections. For all that appears, these sections are afterthoughts not adequately coordinated with the Lanterman Act itself, with the needs of the mentally retarded, or with community needs for protection.

An illustrative case, drawn from our interviews with the local hospital agents, highlights the problems raised by the application of an unstructured "dangerousness" test to the mentally retarded. A probation officer in a rural central California county reported the following case history:

A retarded young man, 24 years of age, who lived in a small coinmunity, developed the habit of standing outside a local office build$\mathrm{mg}$ and staring through a ground-floor window at a girl working imside. Although the young man, in the words of the Probation Officer, "had never done anything to harn anyone," the girl became frightened of him. She and her parents demanded that something be done. The young man's mother was herself mentally retarded and unable to cope with him. He had a sister living in the country who offered him a home there. This arrangement was satisfactory for a short time, but soon the young man had returned to town and was found standing around public places where townspeople would give him money for food. Several times the young man was picked up by the police; eacli time the Probation Department intervened, "because we didn't feel he was responsible for what he was doing." Finally, the sister agreed to fille a petition asking for the young man's commitment to a State Hospital for the Mentally Retarded. The Probation Officer supported the petition because "we felt he was a nuisance on the streets and that for his own protection this was necessary." The hospital's prograin was explained to the young man, and the Probation Officer felt that he was "quite willing" to go to the hospital. The petition was uncontested; the young inan was not represented by an attorney. The Probation Officer, commenting on the case to our interviewer (an attorney), said, "I think he was entitled to an attorney because actually he hadn't committed a crime."

The use of civil commitment of the mentally ill as a device to rid society of social outcasts has been well recognized. ${ }^{294}$ The traditional use of the state hospital as a place of long-term residence for the mentally retarded performs a similar function. ${ }^{295}$ As the case cited above indicates, however, the "dangerousness" standard may prove even less a safeguard against improper commitment when applied to the mentally retarded than it has when applied to the inentally ill. A mentally retarded person may often be perceived as different in appearance from

293. See notes $246 \& 257$ supra.

294. E.g., Kadish, $A$ Case Study in the Signification of Procedural Due ProcessInstitutionalizing the Mentally Ill, 9 WesterN POLITICAL Q. 93, 95 (1956).

295. See Bramwell, supra note 258, at 339. 
other people; his "undesired differentness" may mark him and create a stigma that produces discomfort in others. ${ }^{206}$ This discomfort, in turn, may be conducive to vague fears and ill-founded apprehensions of violence. That many of the mentally retarded are themselves aware of the stigma placed upon them by society and go to great lengths to avoid its consequences has been suggested by a study of 48 mildly retarded persons who were formerly patients at Pacific State Hospital. ${ }^{297}$ Despite the focusing of attention on the mentally retarded during the 1960 's, there is still great ignorance about mental retardation annong the general public. This ignorance made itself fclt to many of the parents in our study, who spoke of people staring at their child when he accompanied the parent to public places. The combination of discomfort, fear, and ignorance may easily lead to a conclusion that the retarded person is a danger to others, when all that is really established is that his continued presence is unpleasant for others.

Danger to self may also take on special connotations for some of the mentally retarded. As we have seen, several mothers of mentally retarded teenaged girls in our sample expressed the fear that their daughters might be subjected to sexual exploitation if allowed to remain in the community. Hospitalization, rather than community placement, was seen as a necessary protection for their daughters. If the regional center refuses to recommend lospitalization in such a case, how difficult would it be for an anxious mother to persuade a sympathetic judge that allowing her daughter to remain in the community would be dangerous to the girl? The question is probably unanswerable at this time, but some evidence suggests that inappropriate sexual behaviour is used as a basis for institutionalization under present law. ${ }^{208}$ It will be instructive to analyze a 4 or 5-year sample of cases processed under the dangerousness standard..$^{200}$

Surgical sterilization of their daughters was seen as an alternative to hospitalization by a few mothers. This procedure, of course, merely prevents pregnancy without affecting sexual exploitation. Moreover, a study of former patients who had been surgically sterilized prior to their

296. E. Goffman, Stigma 5 (1963). See also tenBroek, The Right to Live in the World: The Disabled in the Law of Torts, in THE LAW of THE POOR 517, 518 (J. tenBroek ed. 1966).

297. R. Edgerton, The Cloax of Competence $205-09$ (1967). See also T. Scheff, Being Mentally Ill: A Sociological Theory (1966).

298. R. EDGERTON, supra note 297, at 111. There is some slight indication in our data that a few judges are already using a dangerousness test for commitment. See table 7, text accoinpanying note 89 supra.

299. As of Dec. 17, 1971, only one mentally retarded person had been judicially committed under the new standard. Telephone conversation with Mrs. Barbara Calais, Chief of the Bureau of Legal Services, Department of Mental Hygiene. This case was decided in Los Angeles County, but no further information is available. 
release from the hospital, concluded that sterilization was profoundly damaging to patients' self-esteem and inhibited their successful adjustment in the community. ${ }^{300}$

Involuntary hospitalization of the mentally ill, even though it is sometimes defended on the basis of society's need for protection, is more commonly justified by the individual's need for treatment that will permit his eventual return to society. ${ }^{301}$ In a recent leading case, Chief Judge David Bazelon has suggested that institutionalization of the mentally ill based on dangerousness may be unconstitutional in the absence of procedural safeguards akin to those common to the criminal law, if treatment is not actually provided after commitment. ${ }^{302}$ The recognition of a constitutional "right to treatment" would have farreaching implications. ${ }^{303}$ Should this principle be extended to the mentally retarded, it is not clear that the commitment standards of the Lanterman Act would withstand the challenge. The Act did not alter the procedures used in California to commit the mentally retarded; it merely superimposed the dangerousness test upon those procedures. Part I of this Article describes how the mentally retarded are committed: the description does not evoke an image of the safeguards of criminal procedure. Furthermore, there is little assurance that the promise of treatment will be fulfilled after commitment. A recent study of the National Health Service Hospitals for the Subnormal in England and Wales concluded that the objective consequences of hospitalization for the vast nuajority of patients are "containment and the relief of familial imcapacity to provide care" rather than medical treatment. ${ }^{304}$ As we lave seen, one of the major purposes of the Lanterman Act was to restrict the use of the state hospitals for the mentally retarded to those patients who have medical problems. ${ }^{305}$ Yet the dangerousness standard does not necessarily identify only persons who need medical treatment. If the state hospitals are now to receive this group of patients merely for purposes of confinement, Chief Judge Bazelon's

300. R. EDGERTON, supra note 297, at 154-56. See also Ferster, Eliminating the Unfit, 27 Oнmo ST. L.J. 591 (1966); cf. In re Cavitt, 183 Neb. 243, 159 N.W.2d 566 (1968), appeal dismissed, 396 U.S. 996 (1970).

301. E.g., Kadish, supra note 294, at 101. See also Roemer, California Examines Compulsory Hospitalization Laws, 24 CALIFORNIA's HEALTH 27 (1966).

302. Rouse v. Cameron, 373 F.2d 451, 455, 458 (D.C. Cir. 1966). See Comment, Involuntary Civil Commitment and the Right to Treatment in Pennsylvania, 15 VIIL. L. REV. 951 (1970).

303. E.g., A Symposium: The Right to Treatment, 57 GEo. L.J. 673 (1969).

304. P. Morris, PUT Away: A SOctological Study of Institutions FOR tHe Mentally Retarded 310-11 (1969). See also Bicklen, Human Report: I, Observations in Mental Health-Mental Retardation Facihties, Nov. 1, 1970 (unpublished manuscript, Workshop on Human Abuse, Protection, and Public Policy, Syracuse University).

305. See text accompanying note 257 supra. 
point that the full range of safeguards appropriate to the criminal law may be constitutionally required seems well taken.

Moreover, a recent case decided by the California supreme court $^{306}$ supports the inference that mentally retarded persons committed under the dangerousness standard may be entitled to a jury trial. The case involved a ward of the California Youth Authority who had been committed there by a juvenile court after a finding that he had molested a child. The ward was aged 19 at the time of commitment and would have been entitled to release at the end of two years or on his twenty-first birthday, whichever was later, ${ }^{307}$ except that his further detention had been ordered based on a finding that he was physically dangerous to the public because of his mental or physical deficiency, disorder, or abnormality. ${ }^{30 s}$ Resisting further detention, he urged that this provision, applicable only to Youth Authority wards, arbitrarily discriminated against him by denying him the right of trial by jury, although jury trial is available to other groups of persons subject to involuntary civil commitment such as mentally disordered sex offend$\mathrm{ers}^{300}$ imminently dangerous persons, ${ }^{310}$ and narcotics addicts. ${ }^{311}$

In examining the procedural safeguards available to these and other groups of persons subject to involuntary commitment, ${ }^{312}$ the court found that only Youth Authority wards and the mentally retarded were subject to involuntary commitment for reasons other than brief observation or emergency care without benefit of a jury trial if requested. ${ }^{313}$ The court characterized the right to a jury trial in an action that may lead to defendant's involuntary confinement, even confinement for the purpose of treatment, as a fundamental right that cannot be granted to some groups and denied to others without a showing of compelling state interest justifying the law and the necessity for distinguishing between different groups. ${ }^{314}$ Since the court was unable to find a compelling state interest for distinguishing between Youth Authority wards, who were denied a jury trial, and mentally disordered sex offenders and narcotics addicts, who are entitled to a jury trial, it held that the denial of a jury trial to Youth Authority wards violated the due process and equal protection clauses. ${ }^{315}$

306. In re Gary W., 5 Cal. 3d 296, 486 P.2d 1201, 96 Cal. Rptr. 1 (1971).

307. CAL. ANN. WeLF. \& INST'NS CODE $\$ 1769$ (West 1966).

308. Id. $\S 1800$ (West Supp. 1971).

309. Id. $\S 6318$.

310. Id. $\S 5302,5303$.

311. Id. $\S \S 3050,3051,3108$.

312. The court also examined commitment provisions applicable to inebriates, the gravely disabled, the suicidal, and the mentally retarded. 5 Cal. 3d at 304, 486 P.2d at 1208, 96 Cal. Rptr. at 8.

313. Id. at $305,486 \mathrm{P} .2 \mathrm{~d}$ at $1208,96 \mathrm{Cal}$. Rptr. at 8 .

314. Id. at 306-07, 486 P.2d at 1209, 96 Cal. Rptr. at 9 .

315. Id. at 308, 486 P.2d at 1210, 96 Cal. Rptr. at 10. 
The state had attempted to defend its differential treatment of Youth Authority wards partly on the grounds that the additional detention proceedings were a continuation of a juvenile proceeding, ${ }^{316}$ as to which no jury trial is constitutionally required, ${ }^{317}$ and that the mentally retarded also are not entitled to a jury trial. ${ }^{318}$ The court brushed aside the first argument with the statement that the additional detention proceeding was applicable only to adults ${ }^{310}$ and the second by pointing out that the state's burden could not be discharged by showing "that alleged mentally retarded persons are similarly discriminated against. $" 320$

It may be inferred from this case that a mentally retarded person has a fundamental right to a jury trial in indetermmate involuntary comnitment proceedings based on his alleged dangerousness to himself or others. It would be difficult for the state to make a convincing showing of compelling interest to justify the continued denial of this fundamental right to mentally retarded adults or to distinguish them from adults subject to additional confinement for purposes of treatment under the jurisdiction of the Youth Authority. If the dangerousness standard is to be retained for mentally retarded adults, a change in the legislation expressly guaranteeing a jury trial would seem appropriate.

Matters may stand differently, however, for mentally retarded minors. The United States Supreme Court held in McKeiver v. Pennsyl$v_{a n i} a^{321}$ that a jury trial is not constitutionally required in delinquency adjudications in juvenile courts, and the California supreme court was careful to limit its holding to adults. ${ }^{322}$ It is not easy to pinpoint in the diffuse reasoning of Justice Blackmun the considerations that led the Court to deny jury trials to juveniles. One major influence, however, seems to have bcen the desire to strike a balance between the traditional informality of juvenile court procedures and the more rigorous safeguards of a fair hearing required by the Court's prior decisions in In re Gault ${ }^{323}$ and In re Winship. ${ }^{324}$ Mr. Justice Blackmun seems to be saying that, in view of Gault's provision of the right to notice, counsel, cross-examination, and confrontation in juvenile delinquency adjudications, and Winship's addition of the reasonable doubt

316. Id. at $305-06,486 \mathrm{P} .2 \mathrm{~d}$ at $1208,96 \mathrm{Cal}$. Rptr. at 8 .

317. McKeiver v. Pennsylvania, 403 U.S. 528 (1971).

318. In re Gary W., 5 Cal. 3d 296, 308, 486 P.2d 1201, 1210, 96 Cal. Rptr. 1, 10 (1971).

319. Id. at 305, 486 P.2d at 1208, 96 Cal. Rptr. at 8.

320. Id. at 308, $486 \mathrm{P} .2 \mathrm{~d}$ at $1210,96 \mathrm{Cal}$. Rptr. at 10 .

321. 403 U.S. 528 (1971) (Blackmun, J.), noted in 70 MiCH. L. Rev. 171 (1971).

322. 5 Cal. 3d at 306, 486 P.2d at 1208-09, 96 Cal. Rptr. at 8-9.

323. 387 U.S. 1 (1967).

324. 397 U.S. 358 (1970). 
standard, jury trial would not really add very much more to the goal of a fair hearing and is therefore unnecessary, especially considering the powerful impetus to establishing full-scale adversary proceedings in the juvenile court that a jury trial would contribute. ${ }^{325}$

Even assuming the accuracy of this reasoning for juvenile court proceedings, it is inapplicable to civil commitment procedures for mentally retarded minors. As we have seen, ${ }^{326}$ the advice of counsel is so rarely present in these cases as to be nonexistent, and the standards maintained for observing the mentally retarded person's rights to notice, confrontation, cross-examination, or simply to be present at his own commitment hearing, have been extremely lax under former practice. Nor is there a tradition, dating back to the turn of the century in the case of the juvenile court, ${ }^{327}$ of justifying the procedural informality of the hearing in the naine of a lofty ideal seeking better treatment for youthful deviants. Therefore, the mentally retarded minor might well be in a better position to demand a jury trial than the juvenile offender, particularly since he is now alone in being subjected to long-term commitment under the dangerousness standard without the protection of a jury.

b. The mentally retarded adult. There remains yet another problem with the new approach to hospitalization for the mentally retarded. A large number of mentally retarded persons who now enter the state hospitals on recommendation of the regional centers do so with the permission of their parents. The parent, as the natural guardian of his child's person, has the right to consent to the child's hospitalization during his minority. When the child reaches the age of majority, however, he becomes emancipated from parental authority. ${ }^{328}$ Prior to the enactment of the Lanterman Act, even the hospitals that did not normally require court commitment of mentally retarded children prior to admission saw to it that their patients were committed to the hospital by a court upon reaching majority. This procedure can no longer be followed except for those persons who are dangerous to themselves or others. If a disagreement develops between a nondangerous mentally retarded adult patient and his parents as to whether he should remain in the hospital, absent the appointment of the parent as guard-

325. McKeiver v. Pennsylvania, 403 U.S. 528 (1971).

326. See text accompanying table 5 supra.

327. See generally Schramm, The Juvenile Court: Its Philosophy and Organization, in The Problem of Delinquency 270-76 (S. Glueck ed. 1959); Mack, The Juvenile Court, 23 Harv. L. REv. 104 (1909).

328. CaL. Crv. Code $\S 204$ (West 1970). Nevertheless, ch. 1501 [1971] Cal. Stat. 694, amending Health \& Safety Code $\$ 38150$, permits voluntary admission of adult mentally retarded persons to state hospitals or private institutions upon application of the person's parent, guardian or conservator. 
ian, the hospital would apparently have no authority to keep him there. The same problem would arise if the parent and regional center agreed to initial hospitalization of an adult mentally retarded person who rejected the plan. ${ }^{320}$ In such cases, the parent may seek appointment as guardian of his adult child in order to regain legal authority over him. If the reduction in commitments of the mentally retarded since July 1 , 1971 , is merely counterbalanced by an increase in the appointment of guardians whose function is to agree to their hospitalization, very little will have been accomplished. Indeed, this result may be a step backward since guardianship, unlike commitment, unambiguously strips the ward of his legal and civil rights.

The Lanterman-Petris-Short Act provided for the appointment of a temporary conservator for a person who is gravely disabled as a result of mental disorder or impairment by chromic alcoliolism. ${ }^{330}$ The temporary conservatorship lasts for one year and confers the authority to hospitalize the conservatee. ${ }^{331}$ This procedure should be extended to the mentally retarded if the use of guardianship becomes unduly expanded over the next several years. Regular conservatorship is, of course, available in proper cases, and does not entail a finding of legal incompetence. Its use may be preferable to guardianship and may become more common as the result of the decreased availability of court commitments for mentally retarded adults.

\section{Guardianship}

The Lanterman Act did not directly amend the Public Guardianship Law discussed in part III of this Article, but it contains two provisions that indirectly affect the operation of that law and may ultimately change its direction. The first provision is the elimination of the Department of Mental Hygiene's authority to be appointed guardian for mentally retarded persons. ${ }^{332}$ The department formerly sought appointment only as guardian of the estate of those mentally retarded persons admitted to state hospitals who required estate management serv-

329. The 1971 legislature has recognized this problem and attempted to remedy it by providing for a right to judicial review of his confinement for any mentally retarded adult in a state hospital who requests his release from a member of the hospital treatment staff or a regional center employee. Ch. 1501 [1971] Cal. Stat. 691, adding $\S 38120$ to the Health and Safety Code. The same provision adds $\S 38123$ to the Health and Safety Code, requiring regional centers to certify, when recommending hospital admission for mentally retarded adults, that neither the mentally retarded person nor anyone else on his behalf has objected to his admission to the hospital. Ch. 1501 [1971] Cal. Stat. 693.

330. Cal. ANn. Welf. \& INST'NS Code $\$ \$ 5350-68$ (West Supp. 1971).

331. Id. $\$ \S 5353,5358$.

332. Cal. ANN. Heatth \& SAFETy Code $\$ 38150$ (West Supp. 1971). See text accompanying notes 134-38 supra. 
ices. The Lanterman Act's stated intent is that this function be performed by the Director of Public Health, acting through the regional centers as provided in the Public Guardianship Law. ${ }^{333}$ Although the formal guardianship appointment has been changed from the Department of Mental Hygiene to the Director of Public Health by the Lanterman Act, the daily operation of this service remains essentially the same: the Department of Public Health has contracted with the Department of Mental Hygiene to permit the latter's guardianship officer to continue to perform the estate management services for the Department of Public Health's mentally retarded wards.

The second provision of the Lanterman Act that affects the Public Guardianship Law is more subtle and may ultimately prove more important. This is the new position of the regional centers in the hospital admission process. ${ }^{334}$ As part III indicates, one of the original inotivations for the unsuccessful attempt to establish the personal surrogate as an independent state officer heading the public guardianship program was to place his office on an equal footing with that of the directors of the Department of Mental Hygiene and the Department of Public Health so that he could effectively protect the interests of the mentally retarded even against the other state agencies charged to serve them. The ultimate choice of the Director of Public Health to perform this function was a coinpromise, but it was acceptable because the regional centers, with their emphasis on community services, were seen as organizationally opposed to the state hospital system administered by the Departinent of Mental Hygiene. Now that the regional centers are to serve as the access to the state lospital system, this organizational opposition is weakened. The Departınent of Public Health, acting through the regional centers, has become the major agency charged with care of the mentally retarded. This new structure may be more efficient than the old one, but it is not obvious that it will be as effective in protecting the interests of the mentally retarded.

One of the major weaknesses of the Minnesota guardianship plan was its use of guardianship to effect institutionalization: the Commissioner of Public Welfare acted both as the guardian of retarded persons and as the state officer with power to place his wards in the state hospitals..$^{335}$ Under the California plan, guardianship is not a prerequisite to the regional center's recommendation of hospitalization, and the current Department of Public Health policy of not seeking appointment as guardian during the lifetime of a parent ${ }^{336}$ further differen-

333. Id.

334. See text accompanying notes 259-71 supra.

335. Levy, supra note 211, at 877-87.

336. Letter, May 7, 1971, supra note 240. Ch. 1501 [1971] Cal. Stat. 693, adding $\S 38121$ to the Health \& Safety Code, requires a court holding a hearing on the release 
tiates the California approach from the Minnesota model. Nevertheless, im cases in which the regional center is both the guardian and the proponent of institutionalization, the agency oversees itself and evaluates its own decisions. Mr. Edgar Pye's earlier prediction that the regional centers stood in danger of being looked upon as "the answer, the solution, and the responsible agency in the community to provide services to the mentally retarded and their families"337 is closer now to reality. What the results will be, in terms of protection of the interests of the mentally retarded, remains to be seen.

\section{The Law and the Mentally Retarded}

It has been established that the mental or physical illness of one of its members places a severe stress on the family's emotional (and often fimancial) resources, threatens its sociopsychological balance, and causes general disruption of fanily life. ${ }^{338}$ Similar effects have been reported in families having a mentally retarded child. ${ }^{339}$ Even foster parents of the mentally retarded have been found to need specialized services and supportive casework. ${ }^{340}$ Furthermore, reports have indicated that, in the past, staff personnel and professionals who work with the retarded, particularly im hospital and public scliool settings, have seen their charges as generally noncurable and their own roles as essentially unrewarding. ${ }^{341}$ Similarly, psychotherapists may find working with the retarded less interesting than with other, more verbal patients and may conclude that the time invested is not adequately repaid by the modest results achieved. ${ }^{342}$ On the other hand, it lias been suggested that retarded persons can benefit from psycliotherapeutic treatment for the resolution of emotional disorders, particularly if the therapist does not permit his own attitudes about mental retardation to inter-

of a hospitalized adult mentally retarded person to order the regional center or Department of Public Health to initiate guardianship or conservatorship proceedings if the adult mentally retarded person lacks a parent, guardian, or conservator. The section does not, however, require the probate court judge to appoint a guardian or conservator unless a showing of necessity for the appointment is inade.

337. Pye, supra note 235, at 7 .

338. Anthony, The Impact of Mental and Physical Illness on Family Life, 127 AM. J. PsYchIaTRY 138 (1970); Goffman, The Insanity of Place, 32 PsYchIaTRY 357 (1969).

339. Davis, Family Processes in Mental Retardation, 124 AM. J. PsychiatRy 340 (1967); Begab, The Mentally Retarded and the Family, in I. Philips, supra note 12, at 71-84.

340. Goldblatt, Foster Family Care for the Mentally Retarded Child, 48 Child Welfare 423 (1969).

341. Berlin, Consultation and Special Education, in I. Philips 279-81; Doll, Recognition of Mental Retardation in the School-Age Child, in I. Philips 60-61; Bramwell, Changing Concepts of Residential Care, in I. Philips 340-41.

342. Szurek \& Philips, Mental Retardation and Psychotherapy, in I. Philips 243-43. 
fere with the treatment. ${ }^{343}$ And it has been noticed that special education teachers are better able to serve the retarded and their families if they are helped to define their own expectations about goal setting and levels of achievernent. ${ }^{344}$

The research reported in this paper suggests that the attitudes of defeat and hopelessness that affect many parents and foster parents of the mentally retarded and that have traditionally impeded the efforts of other professional groups in serving thein have also affected the judges and court personnel who supervise the commitment of mentally retarded persons to state hospitals. The reactions of the judges and court personnel, reported in part I of this Article, indicate that they derive very little pride or satisfaction from their work with the mentally retarded. Since the research design did not include interviews with private attorneys who deal professionally with the mentally retarded and their families, it is not known whether similar attitudes hamper their work. Still, it may be inferred from the almost total absence of attorneys in the commitment process and their low visibility as counsellors for the families of the retarded that this field is not perceived as one in which attorneys are particularly useful except as estate planners. Until very recently there was scant indication in professional legal journals that mental retardation is an area that attorneys should know about or that the mentally retarded and their families are potential clients whom attorneys should be prepared to serve. ${ }^{345}$

If lawyers are now to be encouraged to place their skills at the service of the mentally retarded and their families, it is essential that they inake some effort to understand the nature of mental retardation and the enormous range of individual capacity that exists within that condition. Otherwise, the same stereotypes that formerly led other professionals to consign the mentally retarded to the lifelong residential care that too often resulted in their deterioration may now lead attorneys to advise overly restrictive plans that appear protective but actually prevent developinent. Attorneys, to be effective, must be able to advise parents how to plan for their child's future, rather than merely to carry out plans developed by the parents beforehand.

The legal profession has too often been misled into assuming that its task is simply that of accepting and effectuating plans for children made by parents acting alone or in consultation with other professionals. It has taken the accumulation of 70-odd years of experience with the juvenile court to teach the legal profession that the in-

343. Id. at 243-44.

344. Berlin, supra note 341 , at 291-92.

345. See Comment, Planning for the Mentally Retarded, 1962 Wis. L. REv. 686 (1962). 
terests of delinquent children and those who would save them are not always the same. ${ }^{346}$ Laws protect children against physical abuse by their parents, ${ }^{347}$ although considerations of family privacy and differing standards of child rearing make it difficult to devise appropriate standards to protect children against emotional deprivation. ${ }^{348}$ It is becoming accepted that children need protection during the emotional upheaval associated with the divorce of their parents, although it is still disputed whether this protection should take the form of a guardian ad litem, ${ }^{349}$ an independent advocate, ${ }^{350}$ a family court, ${ }^{351}$ or some other, yet to be proposed, device. The focus of all these concerns is the newly emerging idea that children have their own rights and interests that must be asserted even against those who claim to act in their best interests. The mentally retarded child deserves the respect of being accorded a defender of his rights as well. There is no intention to suggest that attorneys representing the retarded create an atmosphere of conflict between the retarded and their parents or those charged with serving them. It does seem fair to conclude, however, that the law, in its slow progress toward according the full dignity of legal personality to children, ${ }^{352}$ should not be allowed to exclude from its fullest protection mentally retarded children and mentally retarded adults, who have too frequently been consigned to lifelong disabilities of childhood.

346. E.g., F. AlLeN, The Borderiand of Cruminal Justice 43-61 (1964); A. Platt, The ChILd SAVERS (1969); Ketcham, The Unfulfilled Promise of the American Juvenile Court, in JUSTICE FOR THE CHIID 22-43 (M. Rosenheim ed. 1962); Younghusband, The Dilemma of the Juvenile Court, 33 Social Serv. Rev. 10 (1959).

347. E.g., Note, The Legal Response to Child Abuse, 11 WM. \& Mary L. REv. $960(1970)$.

348. E.g., C. Foote, R. LeVy \& F. SANDer, Cases and Materials on Family Law $413-417$ (1966); Boehm, The Community and the Social Agency Define Neglect, 43 Child Welfare 453 (1964).

349. Hanseu, Guardians Ad Litem in Divorce and Custody Cases, 4 J. FAMILY LAw 181 (1964).

350. UNIFORM MARRIAGE AND DIVORCE ACT $\$ 310$ (1970).

351. Kay, A Family Court: The California Proposal, 56 CalIf. L. Rev. 1205, 123637 (1968).

352. Cf. P. Ariès, Centuries of ChILdhoOd (1962). 


\section{California Law Review}

\begin{tabular}{lll}
\hline \hline VoL. 60 & MARCH 1972 & No. 2 \\
\hline \hline
\end{tabular}

\section{BOARD OF EDITORS}

\author{
Notes \& Comments \\ ROBERT C. BARRETT \\ LAWRENCE R. BROWN \\ THOMAS D. Clark \\ HENRY C. EAMES, JR. \\ Auban ANN EISENhardT \\ JAMES C. FOWLER \\ ELAINE T. NeLSON \\ RoBert K. SCHIEBELHUT
}

\author{
Editor-in-Chief \\ DeNnIS S. KarJaLA \\ Managing Editor \\ DAVID L. HAMMETT
}

\author{
Managing \\ HAROLD G. FRIEDMAN \\ SCOTt R. WILLERT \\ Supreme Court Editor \\ CAROL G. HAMMETT
}

\section{Associate Editors}

DAVID M. ACHTERKIRCHEN MARTIN BASISZTA

JOHN F. DAVIS

Charles R. FARrar, JR.

WENDELL H. GODDARD

JEFFREY M. ALLEN

Michael J. BARER

Alice M. BEasley

Stgven S. Bell

Michael J. BERTINETTI

Marsha Siegel Berzon

DAVID F. BOYLE

Gabrielle R. Campbell

WILLIAM F. CAPPS

Craig H. Casebeer

RAYMOND A. DIAZ

JoSEPH P. DiCTuCCIO

MARK S. DODSON
Calvin W. Grigsby

ROBERT L. HARRIS

SPENCER R. KAITZ

ThOMAS M. MURRAY

PaUL E. DORRoH

JAMES DRUMMY

IRA MARK ELLMAN

TENETH JAMES FISHBACH, JR LARY LAWRENCE

ERNESTINE FORREST

HowaRd W. Foss, JR.

David M. GLASS

Peter Grossman

ANN HASSE

LESLIE ANN JOHNSON

RICHARD KALISH

\section{Administrative Assistant \\ PATricia G. SMITH}

Articles \& Book Reviews

JIMMIE HARRIS

LyNN H. PASAHOW

ReX Perschbacher

STEPHEN ZAMORA

Research

STEVEN A. BRICK

RICHARD MaRCUS

LANCE JAY ROBBINS

THOMAS B. ROSENBERG

ZoNa SAgB

Mari Harold Shentield SUSAN J. TAMURA

JACK H. KAUFMAN, JR.

Kevin F. KeLLY

STEPHEN L. KOSTKA

DANIEL J. LEeR

Palmer Brown Madden

Craig D. Miller

Oscar Parra

Thomas E. RaNkIN

Lee Charles Rosenthal

Crarg M. Thomas

JOHN E. THORSON

STEPHEN J. YODER 